\title{
Securities Trading by Banks and Credit Supply: Micro-Evidence from the Crisis
}

\author{
Puriya Abbassi Rajkamal Iyer José-Luis Peydró Francesc R. Tous*
}

\begin{abstract}
We analyze securities trading by banks during the crisis and the associated spillovers to the supply of credit. For identification, we use a proprietary dataset that has the investments of banks at the security level for 2005-2012 in conjunction with the credit register from Germany. We find that - during the crisis - banks with higher trading expertise (trading banks) increase their investments in securities, especially in those that had a larger price drop, with the strongest impact in low-rated and long-term securities. Moreover, trading banks reduce their credit supply, and the credit crunch is binding at the firm level. All of the effects are more pronounced for trading banks with higher capital levels. Finally, banks use central bank liquidity and government subsidies like public recapitalization and implicit guarantees mainly to support trading of securities. Overall, our results suggest an externality arising from fire sales in securities markets on credit supply via the trading behavior of banks.
\end{abstract}

JEL codes: G01, G21, G28.

Keywords: banking, investments, bank capital, credit supply, risk-taking, public subsidies.

*This version is from September 2015. Puriya Abbassi: Deutsche Bundesbank, 60431 Frankfurt am Main, Germany; puriya.abbassi@bundesbank.de; Rajkamal Iyer (corresponding author): MIT, 02142 Cambridge, Massachusetts, United States; riyer@mit.edu; José-Luis Peydró: ICREA-Universitat Pompeu Fabra, CREI, Barcelona GSE, CEPR, 08005 Barcelona, Spain; jose.peydro@upf.edu; Francesc R. Tous: Bank of England and Deutsche Bundesbank, EC2R 8AH London, United Kingdom; Francesc.Rodriguez-Tous@bankofengland.co.uk. We are extremely thankful to Jeremy Stein and a referee for their comments and suggestions, and we also thank Viral Acharya, Nittai Bergman, Jean-Noel Barrot, Markus Brunnermeier, Mathias Dewatripont, Douglas Diamond, Xavier Freixas, Marcel Gorenflo, Stefan Gissler, Xavier Giroud, Zhiguo He, Leonid Kogan, Christian Laux, Christian Leuz, Debbie Lucas, Andrey Malenko, Elena Manresa, Stefanie von Martinez, Sergio Mayordomo, Christoph Memmel, Atif Mian, Jun Pan, Jonathan Parker, Michael Schmidt, Antoinette Schoar, Amit Seru, Andrei Shleifer, Leonid Silbermann, Suresh Sundaresan, Harald Uhlig, Adrien Verdelhan, Annette Vissing-Jørgensen, Björn Wehlert, and seminar participants at MIT, UPF, CREI, Universitad de Navarra, Imperial College, Deutsche Bundesbank, EBRD, ECB, Banque de France, Bank of England, NBER Corporate Finance meetings, and BCBS-CEPR-JFI 'Banking and Regulation: the Next Frontier' workshop in Basel. We thank Santeri Niemelä for his excellent research assistance. Peydró acknowledges financial support from both the Spanish Ministry of Economics and Competitiveness (project ECO2012-32434) and the European Research Council Grant (project 648398). The views expressed in the paper are solely those of the authors and do not necessarily represent the views of the Bundesbank, the Bank of England, nor the Eurosystem. 
"Adverse spillovers from a fire sale of this sort may also take the form of a credit crunch that affects borrowers more generally. Such a credit crunch may arise as other financial intermediaries (e.g., banks) withdraw capital from lending, so as to exploit the now-more-attractive returns to buying up fire-sold assets. Ultimately, it is the risk of this credit contraction, and its implications for economic activity more broadly, that may be the most compelling basis for regulatory intervention."

Jeremy C. Stein, Governor of the Federal Reserve Board, 2013

\section{Introduction}

The financial crisis has triggered a considerable debate both in academic and policy circles about the implications of securities trading by banks. ${ }^{1}$ An important argument in this debate is that - during the crisis - banks may allocate funds to buy fire-sold securities to profit from trading opportunities, in turn reducing credit supply (Shleifer and Vishny, 2010; Diamond and Rajan, 2011; Stein, 2013). While engaging in securities trading can be optimal from a bank's perspective, the need for regulatory intervention might arise because of negative externalities to the supply of credit to the real sector. The externality stems from a temporary distortion in securities prices making it attractive for banks to increase investments in securities, thereby reducing credit supply, which affects borrowers unrelated to the original shock. Moreover, banks may support their trading using government subsidies like central bank borrowing, implicit guarantees, or direct recapitalization by taxpayers. ${ }^{2}$ In fact, there have been recent policy initiatives on both sides of the Atlantic on limiting securities trading by banks (the Volcker rule in the US, the Liikanen Report in the EU, and the Vickers Report in the UK). In this paper, we analyze securities trading by banks in crisis times and also the associated spillovers to the supply of credit to the real sector using both security and credit registers for banks.

On the theoretical front, there is a growing literature that analyzes the role of securities trading by banks during a crisis and its implications for credit and securities markets. Diamond and Rajan (2011) show that fire sales in securities markets can lead banks that are actively involved in trading to hold on to their existing investments in illiquid securities and buy more of the fire-sold securities, leading to a credit crunch. ${ }^{3}$ Shleifer and Vishny (2010) show that during a crisis, as a result of fire sales in securities markets, the returns from investing in distressed securities are higher than the returns from lending. In sum, these papers argue that in the presence

\footnotetext{
${ }^{1}$ Securities trading by banks has assumed significant importance in the modern financial system (Langfield and Pagano, 2014), with commercial banks nowadays holding a large amount of securities in their asset portfolios (e.g., $20 \%$ in the US and $19 \%$ in Germany).

${ }^{2}$ We thank an anonymous referee for guiding us to pursue this direction.

${ }^{3}$ See also Uhlig (2010) who argues that finite resources of investors with trading expertise and uncertainty aversion are important factors in explaining the fire sale prices observed in the 2008 financial crisis.
} 
of funding constraints, banks with trading expertise may reduce credit supply as they withdraw funds from lending to profit from trading opportunities.

The main constraint that has hampered empirical research is the lack of comprehensive micro data at the security level on banks’ trading activities. Comparing aggregate data on banks’ securities holdings does not present a precise, clear picture of investment behavior as it does not take into account the time-varying, unobservable heterogeneity in security characteristics (e.g., risk, liquidity, outstanding volumes, etc.). Aggregate data may show that two banks have very similar overall level of security investments, however, the composition of securities could be very different (e.g., risk, maturity, etc.). For instance, observing an increase in securities holding does not necessarily mean that banks are buying fire-sold securities, as it may be due to an increase in holdings of highly rated, very liquid securities, resulting from a 'flight to safety' during a crisis.

In this paper, we use a unique, proprietary dataset from the Bundesbank (the German central bank) that provides information on security-level holdings for all banks in Germany, a bank-dominated system, at a quarterly frequency for the period between 2005 and 2012. Each security is also matched with security-level information, notably price, rating, coupons, and maturity. The exhaustive detail on security-level holdings of each bank allows us to examine the characteristics of the securities traded by banks and also the timing of trading. Importantly, not only do we have the security-level holdings of each bank, but also the credit register containing information on the individual loans made by banks. The security and credit registers are matched with comprehensive bank balance sheet information.

The main testable hypothesis, which we examine in the paper is that - during a crisis banks with higher trading expertise will increase their investments in securities, especially in securities that had a (larger) price drop, to profit from the trading opportunities, thereby withdrawing funds from lending. To examine this channel, we first study the investment behavior of banks that are most active in securities markets. The idea being that, in an environment where fire sales occur, banks that are generally active in the security business are better at identifying trading opportunities, as compared to other banks that do not routinely engage in high levels of securities trading.

To proxy for active presence and expertise in securities markets, we use the notion that banks that generally engage in trading activities and thus have expertise will have a trading desk 
in place and the necessary infrastructure, such as direct membership to the trading platforms to facilitate trading activities. Using this line of reasoning, we proxy for trading expertise by direct membership of banks to the largest, fixed-income trading platform in Germany (Eurex Exchange). Supporting this classification, we find that the amount of securities bought and sold (as a fraction of total assets) are consistently larger for banks with trading expertise, across all the periods. We also find this measure to be highly correlated with fraction of trading income to net income (in the pre-crisis period), with a correlation coefficient of 0.6. Thus, the trading expertise dummy is highly correlated with banks that have a higher fraction of income generated from trading activities.

For identification, we analyze the data at the security-quarter-bank level and include security*time fixed effects (in the benchmark regressions) to account for the unobserved timevarying heterogeneity across securities, e.g., risk, liquidity, outstanding volumes, and level of issuance (the supply of securities). Thus, we examine the changes in level of holdings for the same security in the same quarter by different banks. We also analyze some specifications with bank fixed effects to control exhaustively for time-invariant heterogeneity across banks. Finally, we identify the associated lending behavior of banks by analyzing borrower-quarter-bank level data and controlling for time-varying, unobserved firm fundamentals that proxy for credit demand by using borrower*time fixed effects (see, e.g., Khwaja and Mian, 2008). Thus, we compare lending by different banks to the same firm during the same quarter.

In crisis times, we find that banks with higher trading expertise (“trading banks”) increase their level of security investments as compared to other banks (“non-trading banks”). ${ }^{4}$ For trading banks, unconditionally (without any controls), securities as a fraction of total assets increase from $19 \%$ in the pre-crisis period to $23 \%$ during the crisis, whereas there is no significant change for non-trading banks. In the aggregate, the increase in securities holdings by trading banks corresponds to around 144 billion Euros, which is equivalent to 6\% of the GDP of Germany (as of 2007). ${ }^{5}$ Moreover, trading banks especially buy more of the securities that had a larger drop in price. The investment in securities that had a larger drop in price is primarily concentrated in low-

\footnotetext{
${ }^{4}$ Note that securities as a fraction of total assets for non-trading banks are not trivial (18\% on average), though these banks buy and sell - i.e., trade - a substantially lower fraction of their securities in each period as compared to trading banks. We define the crisis period starting in the third quarter of 2007, when banking problems surfaced, to the last quarter of 2009, when Germany came out of the economic recession. The results are not sensitive to the way we define crisis period.

${ }^{5} \mathrm{He}$, Khang, and Krishnamurthy (2010) also find that the securities holdings of US banks increased over the crisis.
} 
rated (non triple A) and long-term securities. In the crisis period, trading banks invest nearly 64 billion Euros in securities that are in the bottom 25 percentile in terms of price drop.

The investment behavior of banks can be illustrated by the following example. One can see from Figure 1 (left panel) that the price of a JP Morgan medium-term note starts dropping sometime beginning 2007:Q2 till 2009:Q1 (falls from 100 to 85 Euro cents). ${ }^{6}$ Around this period, German banks with higher trading expertise increase their holdings of this JP Morgan note (right panel). After the price rebounds back to 100 over the subsequent quarters, trading banks reduce their holdings. In fact, the buying behavior by trading banks is concentrated in quarters where the security prices are falling. Thus, trading banks accumulate securities whose prices fell in previous periods. In contrast, other banks do not increase their holdings around this period (dashed line).

\section{FIGURE 1}

(a) Market price of a seven-year JP Morgan note

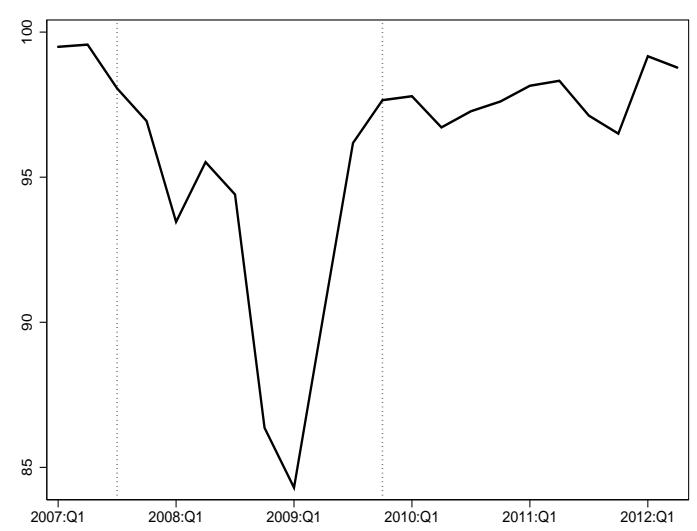

(b) Securities holdings of the seven-year JP Morgan note

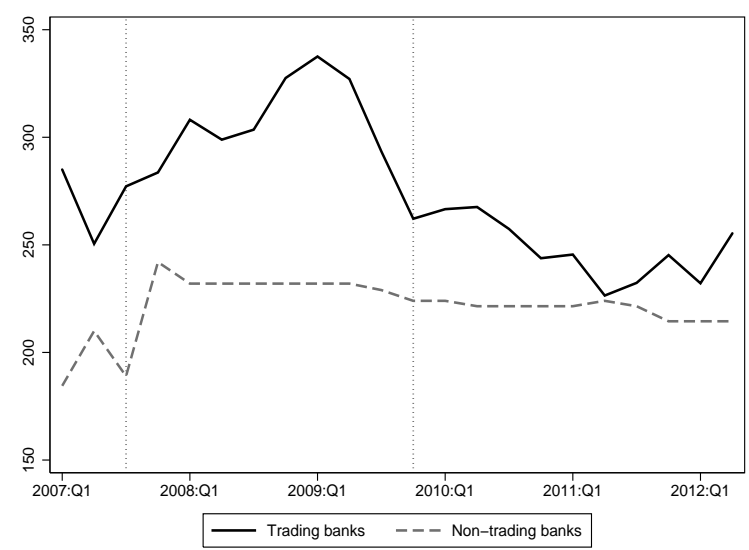

More formally, using a regression framework with controls, we find that trading banks buy more of the securities that had a larger drop in price in the previous quarter, especially lowrated and long-term securities. Focusing narrowly on securities with the largest price drops (bottom 25 percentile in terms of price drop in the previous quarter), we again find that trading banks buy a significantly higher volume of these securities. The results are robust to inclusion of controls for bank characteristics, bank fixed effects to account for unobserved, time-invariant

\footnotetext{
${ }^{6}$ Subfigure (a) shows the monthly price development of the seven-year JP Morgan medium-term floating rate note. Subfigure (b) depicts the Euro-denominated holdings (in millions) of this security by trading banks and non-trading banks. The first vertical line refers to the start of the financial crisis in 2007:Q3 (July $1^{\text {st }}$, 2007) and the second vertical line denotes 2009:Q4, the end of the crisis in Germany. See also Fig. A1 in the Appendix for investments in Greek government bonds by trading and non-trading banks. We find increasing investments by trading banks in these securities at the point when CDS spreads of Greece were widening.
} 
characteristics of banks, or security*time fixed effects to control for time-varying, unobserved security characteristics.

We further examine whether there are differences in trading behavior based on other key bank characteristics. We find that the level of investments in securities that had large price drops is increasing in the level of capital for trading banks. Moreover, trading banks that have higher unrealized losses in securities held in their portfolio buy less of these securities. More generally, for all banks, higher unrealized losses arising from securities in a bank’s investment portfolio are also associated with lower volume of purchases of securities that had a larger drop in price.

We also examine banks' trading behavior depending on the use of public liquidity provided by the Eurosystem/European Central Bank (ECB) or direct and indirect public subsidies by taxpayers. As a proxy for direct subsidies, we use bank-level information on recapitalization and liquidity availed from the central bank (Eurosystem/ECB); to proxy for implicit guarantees, we use a dummy for bank ownership (Landesbanks). We find that trading banks with higher liquidity from the central bank buy more of the securities that have large price drops. Moreover, we find that banks that get recapitalized buy a higher volume of securities that had large price drops, both before and after recapitalization. Finally, we find that Landesbanks buy more of securities that had large price drops. Interestingly, for Landesbanks, we do not find any relation depending on capital on trading behavior; i.e., differently from trading banks, balance sheet strength is not associated with buying behavior for Landesbanks. That is, weaker Landesbanks buy similar volume of securities that had large price drops, as Landesbanks with stronger balance sheets.

Examining the selling behavior of banks, firstly, we find that the volume of sells drops considerably for banks in the crisis. While we find that trading banks sell more as compared to non-trading banks, in the aggregate they add to their holdings of securities, especially of securities that had large price drops (the volume of buys of securities with large price drops substantially exceeds the volume of sells). Interestingly, trading banks with lower capital sell less of securities that had large price drops. Similarly, banks in general that have higher level of unrealized losses on securities in their investment portfolio sell less. The effect is more pronounced for banks with higher borrowing from central banks. This is consistent with banks that have higher level of unrealized losses using central bank funding to hold on to their existing investments. 
While we find that trading banks invest more in securities that had a larger price drop, a crucial question that arises is whether this has any spillovers on the supply of credit to the real economy. An important concern is that trading banks lend to corporate borrowers who have different fundamentals such as risk, size, and growth opportunities. We use borrower*time fixed effects to control for time-varying, unobserved borrower fundamentals. Thus, we examine - in the same quarter for the same borrower - whether there is differential lending behavior by banks based on their trading expertise. In addition, based on the differential effects of other key bank characteristics on trading behavior, we also examine whether there are differential effects of supply of credit to firms along these other bank dimensions.

We find that - during the crisis - trading banks decrease their supply of credit to nonfinancial firms as compared to other banks - i.e., for the same borrower in the same quarter, trading banks reduce lending relative to other banks. Furthermore, there is a larger drop in credit supply by trading banks with a higher level of capital. That is, for trading banks, a higher level of capital is associated with a larger reduction in lending as compared to other banks. These results are the mirror opposite of results for security investments by banks with trading expertise. As discussed later, the existence of funding constraints, risk aversion (or risk bearing capacity), and competing returns between securities trading and lending can lead trading banks (especially with higher capital ratios) to increase investments in risky securities and reduce credit supply. Moreover, there are also no significant differences in the subsequent default rates for borrowers between trading and non-trading banks. Thus, there is no differential risk-taking in terms of lending associated with banks based on trading expertise.

With regard to other bank characteristics, we do not find any significant effect of unrealized gains/losses on banks' existing securities portfolio (which controls for potential hangover of losses on existing investments or unrealized profits from trading in the crisis) on credit supply. In fact, as discussed earlier, trading banks add to their holdings of securities that have a large price drop, with the effects being more pronounced for trading banks with more capital. If hangover of losses on existing investments were the main reason for lower credit supply, one would expect the overall effect of trading banks on credit reduction to be smaller (not higher) for banks with a higher level of capital.

With respect to the effect of direct and indirect public subsidies, we do not find any significant effect of borrowings from central bank on lending. We also find no significant 
difference in lending by Landesbanks as compared to other banks. However, banks that get recapitalized reduce lending by more relative to other banks. These findings are in contrast to their trading behavior reported earlier, where banks with direct and indirect subsidies also bought more of securities that had large price drops. All in all, the credit and trading results are consistent with direct and indirect government subsidies mainly enhancing trading in securities that had large price drops, but not the supply of credit to the real sector.

The results on credit availability are moreover binding at the firm level, which suggests that firms cannot compensate for the reduction in credit by trading banks with credit from other banks. We also do not find that firms compensate the reduction in bank credit by market based financing. ${ }^{7}$ Given that credit from trading banks constitutes an important fraction of the total lending in the economy, our results suggest important macro effects. Note that while on one hand our results suggest an externality to the credit supply, on the other hand, banks buying distressed securities could play an important role in providing liquidity to the distressed securities markets.

Finally, in contrast to the crisis, in the pre-crisis and post-crisis periods, all the main effects of trading versus non-trading banks are not present for credit and investments. ${ }^{8}$ That is, while we find that trading banks buy and sell more of securities in the pre-crisis and post-crisis periods, they do not increase their overall investments in securities as a fraction of total assets or reduce lending.

We also examine several potential alternative channels (see Section 3.4) and find that the above results are most consistent with trading banks increasing their investments in securities during the crisis to profit from trading opportunities, which results in crowding out of credit supply by 5 percentage points. In fact, we find that the average realized returns (annualized) on securities investments made, especially after the failure of Lehman Brothers, are approximately $12.5 \%$ over the next year. ${ }^{9}$

\footnotetext{
${ }^{7}$ Note that Germany is a bank-dominated system with bank credit being the main source of finance.

${ }^{8}$ This is consistent with the idea that, in general, when security prices are not very depressed (and also when funding constraints are not binding), there is no significant crowding out of lending due to securities investment. Note, however, that in some quarters of the Euro sovereign crisis, there are significant results. Moreover, before the crisis banks that receive public guarantees also take on higher risk in securities by buying securities that had large price drops (though there is a larger reduction in security prices in the crisis than in the pre-crisis). See Section 3.

${ }^{9}$ See Fig. 5. As later discussed, we compute realized returns in several different ways and find magnitudes between $12 \%$ and 15\% (annualized). Moreover, though we do not have the loan rate at the loan level, the average loan rate in our credit data was approximately 5\% (annualized) during the crisis, thus significantly lower than the return on securities.
} 
These results contribute to the literature that shows that securities trading by banks during a crisis can play an important role in reducing credit supply (Shleifer and Vishny, 2010; Diamond and Rajan, 2011). Our results also contribute to the literature that analyzes liquidity provision by private intermediaries and the role of government intervention through public provision of liquidity (Holmstrom and Tirole, 1998).

The results also add to the empirical literature that examines investment behavior of banks in sovereign debt during the European sovereign crisis (Acharya and Steffen, 2015; Drechsler et al., 2014). ${ }^{10}$ In contrast to these papers, which examine risk-shifting incentives and financial repression by euro area governments, our paper highlights how fire sales in securities markets can have externalities on credit supply through trading behavior of financial intermediaries.

Given our findings on bank capital and securities trading, our results are consistent with models of financial intermediation where the capital level of banks affects their asset demand (Xiong, 2001; Gromb and Vayanos, 2002; Brunnermeier and Pedersen, 2009; Adrian and Shin, 2010; He and Krishnamurthy, 2013; Brunnermeier and Sannikov, 2014). Our results suggest that in a crisis, the capital level of banks plays an important role in their investments in securities markets. Our results suggest that trading banks with higher capital can buy more of the securities that had a larger drop in price, as higher equity capital provides buffers to absorb potential negative shocks in these riskier securities. Moreover, the results are also consistent with models of fire sales and lack of arbitrage capital (Shleifer and Vishny, 1992, 1997; Allen and Gale, 1994, 1998, 2005; Duffie, 2010; Uhlig, 2010; Acharya, Shin, and Yorulmazer, 2013).

Our results also contribute to the literature that examines the effects of shocks to banks on credit supply during a crisis (see, e.g., Ivashina and Scharfstein, 2010; Iyer et al., 2014; Jiménez et al., 2012, 2014). These papers document a decrease in lending by banks during the crisis, especially those banks more exposed to the shock. To the best of our knowledge, we are the first paper that uses detailed data on both security investments and credit - i.e., a security register and a credit register - which are crucial for empirical analysis of the trading behavior of banks in the crisis and the associated spillovers on the supply of credit to the real sector.

Finally, the results also contribute to theories that highlight strong synergies between the assets and liabilities of banks (Diamond and Dybvig, 1983; Diamond and Rajan, 2001; Kashyap,

\footnotetext{
${ }^{10}$ A limitation of these papers is that they only have data on investments in sovereign securities in some particular periods or only collateral posted by the banks with the European Central Bank. In addition, these papers do not focus on credit supply during the crisis.
} 
Stein, and Rajan, 2002; Gennaioli, Shleifer, and Vishny, 2013; Hanson, Shleifer, Stein, and Vishny, 2015). Consistent with Hanson, Shleifer, Stein, and Vishny (2015), our results suggest that - during a crisis - banks have the ability to hold on to and buy illiquid securities due to a safer liability structure, especially banks with higher equity capital and those with access to direct and indirect government subsidies. More broadly, our results suggest that during the crisis, banks played an important role in providing price-support to the distressed securities markets by buying fire-sold securities. In sum, our evidence highlights the importance of examining the balance sheet adjustments of banks in totality to understand the dynamics of the crisis.

The remainder of the paper is structured as follows. Section 2 presents the data. Section 3 presents the estimation approach and discusses the results. Section 4 concludes.

\section{Data}

We use the proprietary security and credit registers from the Deutsche Bundesbank, which is the micro and macro-prudential supervisor of the German banking system. ${ }^{11}$ We have access to the micro data on securities investments of banks (negotiable bonds and debt securities, equities, and mutual fund shares) at the security level for each bank in Germany, on a quarterly frequency from the beginning of 2006 through to the end of 2012. ${ }^{12}$ For each security, banks report the notional amount they hold at the end of each quarter (stock of individual securities). We use the unique International Security Identification Number (ISIN) associated with every security to merge the data on securities investments with (i) Bloomberg to obtain price data (nominal currency, market price); (ii) FactSet to obtain security-level information on rating, coupons, and maturity. Moreover, we supplement this database on securities investments with confidential supervisory monthly balance sheet statistics at the bank level. In particular, we collect monthly balance sheet items such as each bank’s equity capital, total assets, Tier 1 capital ratio, interbank borrowings, and savings deposits.

Finally, we obtain data on individual loans made by banks from the German credit register maintained by the Deutsche Bundesbank. Banks must report on a quarterly frequency all

\footnotetext{
${ }^{11}$ For micro-prudential regulation, the responsibilities are coordinated with the German federal financial supervisory authority 'BaFin'.

${ }^{12}$ The reporting requirement specifies that securities holdings that are passed on or acquired as part of a repo contract are not double counted in the securities database. Thus, the transactions captured in analysis are not a mechanical artifact of repo transactions. Also, securities holdings of banks in special purpose vehicles are not reported, as these are off-balance sheet items, though we have the aggregate positions of off-balance sheet exposures at the bank level.
} 
borrowers whose overall credit exposure exceeds 1.5 million Euros. Note that lending to small and medium-sized firms is not fully covered by this dataset. However, the credit register covers nearly $70 \%$ of the total credit volume in Germany. The credit register provides information on the amount of loans outstanding at the borrower level for each bank in each quarter. In addition, it also provides information on the date of default (where applicable). The credit register, however, does not record the maturity, collateral, and interest rate associated with the loans.

The complete securities holdings data consist of all securities held by 2,057 banks in the German banking system. We prune the data as follows. We consider only debt securities and exclude equities and shares of mutual funds. As a fraction of total holdings of securities, fixed income securities comprise $99 \%$ of the investments. Then, we delete the securities for which the total holdings for the entire banking sector were below EUR ten million. ${ }^{13}$ The resulting set of securities comprises $95 \%$ of the total holdings. We also exclude from the analysis banks with total assets below EUR one billion, and in addition, we exclude mortgage banks from the analysis. ${ }^{14}$ The sample consists of 517 banks holding $89 \%$ of the securities holdings of the total banking system. Note that we include in the analysis Landesbanks, which are (at least partly) owned by the respective federal state and thus often considered to enjoy an implicit fiscal guarantee.

\section{Results}

In this section, we first discuss the summary statistics. We then present the equations that we use for the estimation along with the results, for both the securities and credit analyses. Finally, we discuss other potential alternative channels and further robustness.

\subsection{Summary statistics and initial results}

As a starting point, Figure 2 presents the evolution of prices over the sample period. We find large price drops in the crisis period (2007:Q3 to 2009:Q4), though there is also a recovery of prices. On average, in some quarters, the average prices of securities drop by around 20\% (annualized price change). We also see that there is wide heterogeneity in the price changes

\footnotetext{
${ }^{13}$ We do this for computational reasons. These securities also account for a very small fraction of the overall asset holdings. We also drop banks below EUR 1 billion in total assets, as these banks are generally not active in securities markets and account for a small fraction of the aggregate securities holdings and credit.

${ }^{14}$ Law prohibits mortgage banks from engaging in (risky securities) investments. The results are robust to including these banks in the sample.
} 
across different securities. There are hardly any significant price drops for securities that are rated triple-A and securities with maturity lower than one year. On the other hand, non-triple-A and long maturity securities have large price drops. This again highlights the importance of examining investment behavior at the security level, since using aggregate data on security holdings would mask these differences and could be misleading.

Table 1, Panel A, presents the summary statistics of the portfolio holdings of banks with (higher) trading expertise decomposed into three subsamples covering the key time periods. We denote the period from 2006:Q1 until 2007:Q2 as the pre-crisis period while we define the subsample 2007:Q3 - 2009:Q4 as the crisis period. ${ }^{15}$ Since 2009:Q4 is the last quarter with yearto-year negative GDP growth in Germany, we refer to the period thereafter as the post-crisis sample.

To empirically proxy for trading expertise of banks, we create a dummy that takes the value of one if a bank has membership to the largest fixed-income trading platform in Germany (Eurex Exchange). ${ }^{16}$ As discussed earlier, the notion is that banks that generally engage in trading activities and have expertise will have a trading desk in place as well as the necessary infrastructure, such as direct membership to the trading platform to facilitate trading activities. Supporting this classification, we find that banks with trading expertise buy and sell a significantly larger fraction of securities (relative to other banks reported in Panel B of Table 1). Both the amount of securities bought and sold (as a fraction of total assets) are consistently larger for banks with trading expertise across all the periods. The correlation coefficient of trading expertise dummy with pre-crisis trading gains as a fraction of net income is close to 0.6. Thus, the trading expertise dummy is highly correlated with banks that have a higher fraction of income generated from trading activities. Furthermore, banks that are generally expected to have large trading desks, such as Deutsche Bank, Commerzbank, Unicredit, etc., show up in the classification as banks with trading expertise. We also estimated the main results using pre-crisis trading revenues as a fraction of total revenues and find similar results to those reported below. We prefer not using the pre-crisis trading revenues as one could argue that they are endogenous

\footnotetext{
${ }^{15}$ For references that the financial crisis starts in Europe in 2007:Q3, see Iyer et al. (2014) and the references therein.

${ }^{16}$ We assume that expertise is required to identify profitable trading opportunities in securities markets during the crisis. See also Gorton and Metrick (2012) and Dang, Gorton, and Holmstrom (2013) for papers that argue about breakdown in trading of debt securities during a crisis due to lack of expertise to evaluate the quality of the debt securities.
} 
to banks performance entering into the crisis and could therefore bias the results. Note that while these banks trade more (buy and sell more) securities relative to other banks in the pre-crisis period, we do not find that they increase their overall fraction of security holdings (in fact, they are similar to other banks in the level of holdings of securities in the pre-crisis). Also, note that we do not include Landesbanks in the trading bank dummy and, instead, separately include a dummy for Landesbanks in the regressions to account for their implicit guarantees.

Interestingly, looking at the securities holdings to total assets, we find - in the crisis period -that trading banks increase their securities holdings. The fraction of securities to total assets increases from $18.8 \%$ in the pre-crisis period to $22.8 \%$ during the crisis. We do not find any significant difference for non-trading banks (from $18.4 \%$ to $18.7 \%$ ). ${ }^{17}$ Thus, unconditionally (without any controls), trading banks on average increase their securities holdings in the crisis period and also relative to non-trading banks. Moreover, it is interesting to note that while the buys as a fraction of total assets increases during the crisis for both trading and non-trading banks, sells as a fraction of total assets decreases.

While the securities holdings of trading banks increases during the crisis, loans as a fraction of total assets decreases. From the pre-crisis level of $66.5 \%$, it decreases to $63.9 \%$ in the crisis. In contrast, for the non-trading banks, loans as a fraction of total assets increases from $69.2 \%$ to $69.6 \%$. Therefore, unconditionally, trading banks on average reduce lending in the crisis and also relative to non-trading banks. Note that, in general, the quality of loans in Germany was not bad and also Germany had a faster recovery from the crisis as compared to other European countries.

All in all, the summary statistics reported above suggest that trading banks increase their overall level of security investments during the crisis and decrease lending. These patterns appear clearly in the data - i.e., comparing only trading banks across the pre-crisis and crisis period, or comparing trading versus non-trading banks in the crisis period with respect to the pre-crisis period.

\footnotetext{
${ }^{17}$ Note that our classification does not exhaust the entire set of banks that have trading expertise. Thus, it is possible that there are other banks in the group classified as non-experts that also have trading ability. This classification bias should reduce the likelihood of us finding any significant differences across the two groups.

${ }^{18}$ The average default rate on loans at the peak of the crisis was 1.59\%. Some of the German banks (mainly Landesbanks) experienced problems due to investments in securities originated by banks from other countries and not from defaults arising from loans to German borrowers.
} 
Not surprisingly, a very similar picture also emerges from a graphical representation of the main variables of interest. Figure 3 presents the investments in securities by trading banks as compared to non-trading banks. Trading banks invest more in securities, especially during the crisis period. Furthermore, in line with Figure 1 (discussed in the Introduction) there is a sharp spike in their security investments in the period after the failure of Lehman Brothers. In contrast, an opposite picture emerges when we look at credit growth (Figure 4). We see that during the crisis, trading banks decrease their credit growth relative to non-trading banks.

Examining the composition of securities holdings of banks, we see that for trading banks, the fraction of triple-A securities to total securities holdings decreases from $58.0 \%$ in the precrisis period to $50.6 \%$ in the crisis (and then increases to $55.6 \%$ in the post-crisis period); instead, for non-trading banks, the fraction of triple-A securities remains stable at around $40 \%$ across the three different periods. Therefore, there are substantial differences in composition of securities across different ratings for trading and non-trading banks. In particular, trading banks not only substantially increase their overall securities holding during the crisis, but they significantly buy more of low-rated securities.

For trading banks, the ratio of long-term securities goes up from $71.7 \%$ in the pre-crisis period to $77.2 \%$ in the crisis (and further to $86.4 \%$ in the post-crisis period); instead, for the nontrading banks, the fraction of long-term securities remains stable in the pre-crisis and crisis periods at around $77-78 \%$. Thus, trading banks also buy relatively more of long-term securities. Therefore, trading banks increase overall investments in the crisis, especially in low-rated and long-term securities (looking only at trading banks across periods or comparing trading versus non-trading banks across periods).

Moreover, for trading banks, the fraction of domestic securities to total securities decreases from $64.1 \%$ to $57.6 \%$ during the crisis period and then further to $48.8 \%$ in the postcrisis period, and the fraction of sovereign securities held decreases from $33.0 \%$ in the pre-crisis period to $30.3 \%$ during the crisis, increasing to $41.9 \%$ in the post-crisis period. Instead, for the non-trading banks, the fraction of sovereign securities is at $18.7 \%$ in the pre-crisis, $16.1 \%$ in the crisis period, and at $19.4 \%$ in the post-crisis period, and the fraction of domestic securities is $78.4 \%$ in the pre-crisis, $71.7 \%$ in the crisis, and further decreases to $66.6 \%$ in the post-crisis period. With regard to off-balance sheet exposures (as a fraction of total assets), in the pre-crisis period, for trading banks, it is $3.9 \%$ and decreases to $3 \%$ in the crisis and further to $2.5 \%$ in the 
post-crisis period. For non-trading banks, the fraction of off-balance sheet exposure is around 1.1-1.3\% across different periods. With respect to size, trading banks are on average larger. Note that in the main regressions we include controls for size and other key bank characteristics. We also find that during the crisis, both trading and non-trading banks increase in size. The average capital ratio (book equity to total assets) is $4.8 \%$ for trading banks in the pre-crisis period and remains at the same level in the crisis (4.8\%), increasing to $5.4 \%$ in the post-crisis period; for non-trading banks, the capital ratio is $5.0 \%$ in the pre-crisis and crisis periods, and $5.2 \%$ in the post-crisis period. Borrowing from the central bank as a fraction of total assets is $2.2 \%$ for trading banks in the pre-crisis period, which increases to $2.8 \%$ in the crisis period, and then drops to $0.9 \%$ in the post-crisis period. For the non-trading banks, borrowings are around $1.3 \%$ of total assets in the pre-crisis period, $2.0 \%$ in the crisis, and $1.1 \%$ in the post-crisis period.

Panel C of Table 1 presents details on the summary statistics for different measures of gains/losses of the securities portfolio held by trading and non-trading banks. Here, we report the summary statistics up to 2009:Q1 as the prices began to revert after that quarter. Thus, 2009:Q1 gives a better picture of the magnitude of losses from securities trading activities of banks. We find that trading banks on average have unrealized losses of $0.3 \%$ of total assets, with some banks in the bottom 10 percentile having unrealized losses above $0.7 \%$. Thus, if these banks had to sell their securities investments, nearly 15\% of their book equity would be wiped out (assuming an average equity ratio of $4.8 \%$ ). On the other hand, we also find strong variation in trading banks, with some banks having very small losses (0.001\% of assets). For non-trading banks, we also find similar patterns with slightly lower magnitude of losses as compared to trading banks. When we examine the losses arising from the investments made by banks in the pre-crisis period, we find very similar magnitudes. This suggests that a large portion of the unrealized losses arise from losses on investments made by banks in the pre-crisis period. Panels B and C of Appendix Table A1 reports the detailed summary statistics of these variables for the pre-crisis, crisis, and post-crisis periods.

\subsection{Securities analysis}

We now examine the investment behavior in securities using the micro data. The summary statistics and graphs presented above suggest that - in the crisis period - trading banks increase investments in securities, especially low-rated and long-term securities, and decrease 
credit as compared to non-trading banks. However, as previously explained, to understand the underlying mechanism, and for empirical identification, one needs to formally examine the differential behavior of trading banks relative to non-trading banks using micro-level data both for securities and credit. Using micro-level data allows us to control for heterogeneity in securities, and borrowers, and other bank characteristics. Furthermore, one can better analyze heterogeneous effects across banks in securities trading and lending.

Table 2 reports the results for banks' investment behavior in the crisis period based on trading expertise (and for Landesbanks). ${ }^{19}$ Before we move to the security-level data, we start by examining whether trading banks increase their overall fraction of investments in securities relative to non-trading banks. In column 1 of Panel A, we examine at the bank level the quarterly change in the level of securities holdings as a fraction of total assets in the crisis period. We find that trading banks increase their level of securities holdings relative to non-trading banks over the crisis period. This result lines up with the summary statistics and Fig. 3, where we find that trading banks increase their securities holdings in the crisis. Therefore, both conditionally (controlling for other bank characteristics in Table 2) and unconditionally (without any control in Table 1 and Fig. 3), we find that trading banks increase their level of investments during the crisis. Moreover, to account for implicit guarantees, we include a dummy for Landesbanks. We find that the coefficient on Landesbank dummy is positive but not statistically significant at conventional levels. Later in the analysis, we examine more directly the effects of explicit and implicit government subsidies on trading behavior.

We next move on to separately examining buying and selling behavior across securities. Our model for buying and selling behavior is at the security-quarter-bank level. This allows us to analyze security-level heterogeneity while controlling for time-varying, unobserved heterogeneity in securities. The model takes the following form:

$$
\text { Log }\left(\text { Amount buy } / \text { sell }_{i_{i b t}}=\beta \text { Trading expertise } \text { Tr }_{b}+\alpha_{i t}+\text { Controls }_{b t-1}+\varepsilon_{i b t}\right.
$$

where Amount refers to the nominal amount bought ('buy') or sold ('sell') of security 'i' by bank ' $b$ ' at quarter 't', and zero otherwise - i.e., when there is a buy, we calculate the nominal amount by calculating the absolute difference in the holdings between quarter ' $\mathrm{t}$ ' and quarter ' $\mathrm{t}-1$ ' and then taking the logarithm of this amount. For example, when examining buying behavior, the

\footnotetext{
${ }^{19}$ In some of the estimations, the number of observations varies due to missing data. However, this does not affect the robustness of the results.
} 
dependent variable takes a positive value if the bank has a net positive investment in the particular security and zero if there is no change in the level of holdings or if there is a net sell of the security. We also include in the benchmark regressions security*time fixed effects $\left(\alpha_{\mathrm{it}}\right)$ to control for time-varying, unobserved characteristics of individual securities. ${ }^{20}$ Note that inclusion of security*time fixed effects controls for all unobserved and observed time-varying heterogeneity, including all the price variation in securities, thus the estimated coefficients are similar whether we use nominal holdings or holdings at market value as a dependent variable.

We use Eq. (1) as a baseline and modify it based on the hypothesis we are testing. In some estimations, depending on the question we analyze, we exploit interactions of bank variables (e.g., trading, capital, gains/losses, and implicit and explicit government subsidies) and security variables (e.g., price variation in the previous quarter). Furthermore, we can also include bank fixed effects to account for time-invariant heterogeneity in bank characteristics.

In columns 2 and 3, Panel A, we examine the overall buying and selling behavior of banks at the security-quarter-bank level. We find that trading banks in general buy and sell more of securities as compared to non-trading banks (nearly twice as much, with a higher coefficient for buying than selling). ${ }^{21}$ Notice that these estimations include controls for bank size, capital, interbank borrowing, and deposits. These results from columns 2 and 3 further help to validate our classification of banks with higher trading expertise. We also find that the coefficient on Landesbank dummy is positive and significant. Thus, apart from trading banks, Landesbanks also buy and sell more of securities as compared to other banks. In columns 4 and 5, Panel A, we add security*time fixed effects and find similar coefficients as in columns 2 and 3 . We also find a similar pattern when we examine buying behavior across securities with different ratings and maturity (see Appendix Table A8).

We also examine whether there are differences in the composition of investments, conditional on buying (see Panel B of Table 2). One would expect that, conditional on buying a

\footnotetext{
${ }^{20}$ Security*time fixed effects are a multiplication of a dummy for each security and dummy for each quarter - that is, these set of fixed effects are substantially stronger than adding just security and time fixed effects in an additive way. Therefore, the inclusion of security*time fixed effects also helps us to control - in each time period - for how much of each security is issued and outstanding and, therefore, isolate the demand of securities. Also, when we use security*time fixed effects, we do not control for security-level variables (in levels) as these are absorbed by the fixed effects. Moreover, notice that we analyze the main left-hand side variables in changes (securities changes, both buys and sells, and credit growth) to reduce concerns of autocorrelation and to better analyze the change in behavior of banks.

${ }^{21}$ We also ran the estimations where the dependent variable takes the value of one if the bank has a net positive investment in a security and zero otherwise, and we find similar results.
} 
security, banks with higher trading expertise would purchase more of securities that had a larger price drop (in the previous quarter) as compared to other banks. The summary statistics described earlier also point in this direction (trading banks increase their holdings of low-rated and longterm securities in the crisis). To examine this, we estimate Eq. (1), restricting the sample only to securities and banks where there are buys.

In column 1, we find that trading banks buy more of the securities that had a larger percentage drop in price in the previous quarter (interaction of trading expertise dummy and lagged percentage change in price). Note that we introduce bank fixed effects, in addition to security*time fixed effects, to take into account time-invariant heterogeneity in bank characteristics and to isolate the compositional effects of buys. In columns 2 to 5, we analyze compositional effects depending on rating and maturity. We find that the effects are not significant for triple-A and short-term securities but are significant only for non-triple-A rated securities and securities with a maturity longer than one year. Moreover, we also find that Landesbanks buy more of securities that had a larger percentage drop in price, especially lowrated securities and securities with remaining maturity longer than one year.

In Panel $\mathrm{C}$ of Table 2, we examine whether banks differ in the composition of securities they sell. Panel C is identical to Panel B, the only difference being that we examine sells. As one can see, we do not find any significant differences in selling behavior for securities that had a larger drop in price across banks based on trading expertise. We also do not find any compositional effects depending on rating or maturity, except for Landesbanks that sell less of securities with maturity less than one year that had a larger drop in price. Put differently, they sell more of the securities with maturity less than one year whose prices increased in the previous quarter.

The results above show that trading banks and Landesbanks buy more of securities that had a larger percentage drop in price. However, in order to focus more on potential fire sales (securities with large price changes that are potentially temporary), we examine more narrowly the trading behavior of banks for securities with the largest price drops (bottom 25 percentile of price drops). In Table 3, we replicate the analysis reported in Table 2 (Panel A) for securities that have the largest price drops. From column 1, we can see that trading banks increase their 
holdings of securities with the largest price drops. ${ }^{22}$ The amount invested in these securities by trading banks is substantial. As discussed earlier, trading banks invest nearly 64 billion Euros in these types of securities during the crisis. Columns 2 to 5 report the coefficients for overall buying and selling behavior of banks at the security-quarter-bank level. We again find that both trading banks and Landesbanks trade more of securities that have the largest price drops (see also Appendix Table A8, Panel A).

We then examine whether there are differences in the level of investments in securities with the largest price drops based on other key bank characteristics. In Table 4, we start by analyzing the effect of unrealized gains/losses on securities held in the bank's portfolio on trading behavior. We report the results for several measures of unrealized gains/losses. In column 1, we examine the unrealized gains/losses on all pre-crisis holdings of securities. We find that banks with higher losses on their pre-crisis holdings of securities buy less of securities with the largest price drops. In column 2, we limit the set of securities among the pre-crisis holdings to subprime securities (CDOs, MBSs, and ABSs). We again find that banks with higher losses on pre-crisis holdings of subprime securities buy less of securities with the largest price drops. In fact, the overall effects are substantially larger for banks with higher losses on subprime securities (CDO, ABS, MBS) than other securities, as can be seen from the coefficients on column 2 versus column 1.

In column 3, we measure unrealized gains/losses at the security level rather than at the bank level. The positive coefficient implies that banks buy less of securities in which they have accumulated higher losses in their existing portfolio. In column 4, we examine the effect of losses on the entire security holdings of banks (not limited to pre-crisis securities). Again we find similar effects. All in all, from columns 1 through 4, we find that banks that experience higher losses on their existing securities investments buy less of securities that experience the largest price drops.

We also find that banks with higher pre-crisis exposure to subprime securities in their investment portfolio engage in less buying (column 5). While so far we examined the effect of investments held on the banks balance sheet, in column 6 we study the effect of off-balance sheet exposures of banks on trading behavior. As can be seen, we do not find a significant effect of

\footnotetext{
${ }^{22}$ Note that some of the banks do not invest in securities that are in the bottom 25 percentile of price drops. Therefore, the number of observations is different from those in Table 2, Panel A, column 1. However, even if we code these to be zero, it does not alter the results.
} 
higher off-balance sheet exposure on buying behavior. These results suggest that larger losses on securities holdings negatively impacts buying of securities with large price drops, but there is no effect of higher fraction of (ex-ante) off-balance sheet positions on buying behavior. ${ }^{23}$ In columns 7 and 8, we measure the effect of realized gains/losses on derivatives and overall profits from trading, respectively, on buying behavior. Interestingly, in contrast to unrealized profits/losses, in columns 7 and 8, we do not find any significant effect. In column 9, even if we control for unrealized gains/losses, we do not find any effect of realized gains/losses on buying behavior. As later discussed, this is consistent with banks holding on to their losses, which in turn reduces the predictive power of realized gains/losses.

The results in Table 4 highlight that the strength of the bank balance sheet matters for trading behavior. The natural question given these results is whether the buying behavior of trading banks and Landesbanks varies based on their balance sheet strength (i.e., interactions of trading bank and Landesbank dummies with variables related to bank balance sheet strength). From Table 5, column 1, we see that volume of buys is increasing in the level of unrealized gains for trading banks. Furthermore, we also examine the effect of bank capital on buying behavior. As previously discussed, the capital level of banks could proxy for risk-bearing capacity. We find that - for trading banks - higher (lagged) bank capital implies a higher level of investments (buys) in securities that experience the largest drop in price (column 2). ${ }^{24}$ In terms of economic magnitudes, a one percentage point increase in capital-to-asset ratio is associated with a 33.8\% increase in the amount of securities bought by trading banks. Also, note that the coefficient on the interaction term of trading bank and gains decreases both economically and in terms of statistical significance once we introduce the interaction of trading bank and capital.

While capital level of banks could proxy risk-bearing capacity, another possible interpretation could be that banks with higher capital buy more of securities that have large price drops because the regulatory capital limits are less binding. Thus, to further understand whether the results are driven by regulatory capital constraints, we also include an interaction term of trading bank and regulatory capital (Tier 1 capital buffer) in the specification. As can be seen, we do not find any effect of regulatory capital on buying behavior, while the interaction with capital

\footnotetext{
${ }^{23}$ Note that we do not have disaggregated data on off-balance sheet positions.

${ }^{24}$ The results are robust to inclusion of bank fixed effects or bank*security fixed effects and also double clustering at the bank and security level (as well as all the other main results of the paper). We also find similar results when we estimate the model using the equity level measured as in 2007.
} 
ratio (the inverse of leverage ratio) remains significant (column 3). This suggests that the effect of capital on buying behavior for trading banks is more likely to be due to risk-bearing capacity associated with capital levels rather than pure regulatory constraints. ${ }^{25}$ Also, most banks in Germany follow the German local GAAP (HGB) for regulatory reporting and for reporting financial statements. Under HGB, historical cost accounting prevails in contrast to fair value accounting (IFRS). This suggests that the association of capital and buying behavior is unlikely due to mark-to-market accounting concerns (Laux and Leuz, 2010). ${ }^{26}$

In column 4, we examine the interaction term of Landesbank dummy and gains on securities and find that it is not significant. In column 5, we report the interaction of Landesbank dummy and capital. Again, we find no significant effect of capital on buying behavior of Landesbanks. Thus, Landesbanks continue buying irrespective of their balance sheet strength (either in capital or gains), in contrast to trading banks where balance sheet strength matters for buying. ${ }^{27}$ This suggests that the implicit public guarantees make banks insensitive to risk allowing them to continue buying securities that have large price drops without the necessary balance sheet strength.

The results reported so far show that trading banks buy more of securities that have the largest drop in price, with the effect being more pronounced for banks with higher capital and gains. We also find that Landesbanks buy more of the securities that have the largest drop in price. However, their buying behavior is not sensitive to the strength of their balance sheet (capital and gains). Given that Landesbanks, which are perceived to have implicit government guarantees, engage in buying securities that have the largest price drops, one could ask whether

\footnotetext{
${ }^{25}$ Note that the correlation between capital ratio (inverse of leverage ratio) and Tier 1 capital buffer is 0.4. Thus, even though there could be some multicollinearity, we still find that capital ratio is significant. Also, the finding that the inverse of leverage ratio has higher explanatory power as against Tier 1 capital buffer is consistent with other evidence that suggests that banks actively manage their Tier 1 ratios, and hence it is a less reliable measure. For instance, most banks that experienced severe distress (even failed) during the crisis in the US appeared to be very well capitalized based on Tier 1 regulatory ratios. Notice also that our measure of capital ratio (inverse of the leverage ratio) was not regulated in Germany as well as other European countries until the recent capital agreements of Basel III. We also do not find any significant effects of Tier 1 buffer on lending behavior (not reported).

${ }^{26}$ Under HGB, securities must be written down to the market value only when the market value falls below the reported amortized cost (unlike mark-to-market accounting). Thus, only when there is a decrease of the market value below historical cost is there a direct impact on net income. We do not have the data on categorization for banks, but German banks are mostly using historical cost accounting (see Georgescu and Laux, 2013).

${ }^{27}$ As later discussed, we also find that trading banks reduce lending but Landesbanks do not reduce lending (see Table 8). Also in Appendix Table A5, we find that the coefficient on the interaction of trading*change in credit and the interaction of trading*capital*change in credit is negative on buying, thus suggesting the substitution effects between securities and credit, especially for trading banks with higher capital.
} 
other explicit government guarantees also play a role in supporting trading activities of banks. In Table 6, we examine whether banks that buy securities that have the largest price drops also use explicit government subsidies to support their trading activities. In particular, we examine if use of public liquidity from the central bank and direct recapitalization by taxpayers is associated with more buying of securities with the largest price drops.

From column 1 we can see that the recapitalization dummy is positively associated with more buying behavior of securities with largest drop in prices. The positive association could arise due to banks that get recapitalized buying more of securities in general. Alternatively, it could be that before recapitalization, these banks buy more of the securities that had a large drop in price and experience trouble as prices of these securities continue to drop. In column 2, we split the recapitalization dummy to examine the behavior of banks before and after recapitalization. Interestingly, we find that banks that get recapitalized buy more both before and after recapitalization.

In columns 3 to 5, we examine the buying behavior of banks that avail public liquidity from the central banks. Note that the liquidity provided by central banks during the crisis was at very low rates, lower than that offered by the market, and hence it was a form of public subsidy for banks. We find that the interaction term of the amount of borrowing and trading bank dummy is positive. That is, for trading banks, public liquidity from the central bank supports higher buying of securities with large drop in price. These results are consistent with trading banks leveraging up using public borrowing from the central bank to profit from (potential) fire sales. Note that the level effect of public borrowing and its interaction with Landesbank are not significant. However, the interaction with gains is positively significant, thus suggesting that banks with higher gains leveraged more with the Eurosystem liquidity to buy securities. In column 5, we estimate the results including both borrowing from central bank and recapitalization in the same specification and find similar results (Appendix Table A2 reports the results for all securities).

In Table 7, we investigate whether banks that received public backstops in the crisis engaged in higher risk taking in asset markets during the boom (pre-crisis period). We find that Landesbanks and banks that received public recapitalization buy more of securities that have the largest price drop also during the pre-crisis period. Thus, these banks have a larger fraction of risky securities in their trading portfolio in the pre-crisis period as compared to the other banks. 
These results suggest that banks that take on more trading risk in the pre-crisis period receive higher public backstops, and then increase even more towards trading in the crisis. Thus, the results are consistent with banks that anticipate public backstops increasing their risk taking even during boom. From columns 1 to 3, we also find that trading banks invest more in securities that had the largest price drops even in the pre-crisis period. Thus, consistent with their business model trading banks actively engage in buying of securities with high-expected return even in the pre-crisis period. However, different from Landesbanks, we find that volume of buys of trading banks in riskier securities is increasing in the level of capital. For unrealized gains on their holdings, we find similar effects for trading banks and Landesbanks. ${ }^{28}$

Even though - in the aggregate - trading banks and Landesbanks add to their holdings of securities that had large price drops, it is also important to understand whether bank characteristics differentially affect the selling behavior. Recall that, in the summary statistics table, we find that banks in general substantially decrease their selling during the crisis.

In Table 8, column 1, we find that banks with higher losses on securities sell even less of the securities that had the largest price drop. While capital by itself is not significantly associated with selling behavior, we find that the interaction term of trading bank and capital is significant. In particular, trading banks with lower capital levels sell less of securities of the securities that had the largest price drop. Thus, banks with weaker balance sheets do not sell as much as stronger ones, thus holding on to securities that fell in price, and hence not realizing the losses. Moreover, we do not find any significant effect of capital or gains on securities for the selling behavior of Landesbanks.

In columns 2 and 3, we introduce the recapitalization dummy. We find that banks that are recapitalized sell more of securities, both before and after the recapitalization. Also note that the Landesbank dummy is only weakly significant once we introduce controls for recapitalization, although the estimated magnitude remains similar. Moreover, in column 4, we examine public borrowings from the central bank. We find that banks with higher central bank borrowing sell more of securities, but the coefficient is not significant (see also Table A7 of Appendix for the results for selling behavior of all securities). However, when we introduce the interaction term of central bank borrowings with unrealized gains/losses on securities, we find that the coefficients

\footnotetext{
${ }^{28}$ As discussed later even though banks buy riskier securities in the pre-crisis period, they do not increase their overall level of securities holdings in the pre-crisis period as the large drop in security prices only occur during the crisis.
} 
on both central bank borrowing and its interaction with unrealized gains/losses are positive and significant (column 5). Thus, banks with more central bank borrowing sell more of securities. However, with higher public provision of liquidity, the extent of selling is lower for banks with more unrealized losses. This is consistent with provision of central bank funding allowing banks to hold on to losses from securities trading. Finally, in column 6, we include both recapitalization dummy and borrowings from the central bank in the same specification and find similar results to those reported. $^{29}$

Overall the results show that - during the crisis - banks with higher trading expertise increase their overall investments in securities, especially in those that had large price drops. We also find that these effects are stronger for trading banks with higher gains and capital levels, differently from Landesbanks, whose buying behavior is insensitive to balance sheet strength. We also find that banks with weaker balance sheets sell less of securities with large price drops, with the effects more pronounced for trading banks. Moreover, our results suggest that central bank liquidity and direct or indirect government subsidies support trading activities. Given these results on securities trading, a crucial question that arises is whether these trading activities by banks have spillovers on credit supply.

\subsection{Credit analysis}

To examine the lending behavior of banks, we exploit the data at the borrower-bank-time level. We use the following estimation equation:

$$
\Delta \text { Log }{\text { (loan } \text { credit }_{j b t}=\beta \text { Trading expertise }}_{b}+\gamma_{j t}+\text { Controls }_{b t-1}+\varepsilon_{j b t}
$$

where the dependent variable is the change in the logarithm of credit granted by bank $b$ to (nonfinancial) firm $j$ during quarter $t$. We use borrower*time fixed effects $\left(\gamma_{j t}\right)$ to control for timevarying, unobserved heterogeneity in borrower fundamentals (e.g., risk and growth opportunities) that proxy for credit demand (see, e.g., Khwaja and Mian, 2008). Thus, we compare the change in the level of credit for the same borrower in the same time period across banks with different levels of trading expertise. Moreover, we also analyze the effect of other bank characteristics on credit supply, thus mimicking the security analysis. Finally, we also analyze whether there are implications for credit availability at the firm level (using aggregate changes in firm credit).

\footnotetext{
${ }^{29}$ We also examined interactions of recapitalization dummy and unrealized gains and interaction of trading dummy or Landesbank dummy with borrowings and did not find any significant effects (not reported).
} 
In Table 9, column 1, we start by examining the lending behavior of banks based on trading expertise relative to other banks during the crisis. We find that banks with higher trading expertise lend less relative to other banks. In column 2, we include borrower*time fixed effects to proxy for credit demand. We find that banks with (higher) trading expertise lend less to the same borrower (firm) at the same time as compared to other banks. The lending by trading banks is five percentage points lower than that of non-trading banks.

In column 3, we examine whether trading banks with higher capital reduce lending by more. For banks with higher trading expertise, we find that higher capital is associated with a larger decline in credit supply. Thus, consistent with the models discussed earlier, trading banks with higher capital invest more in securities and also reduce the supply of credit by more (see He and Krishnamurthy, 2012, 2013). ${ }^{30}$ For Landesbanks, we do not find any significant difference in lending as compared to non-trading banks. Furthermore, there is no significant effect of capital on lending behavior for Landesbanks and non-trading banks.

In column 4, we introduce controls for unrealized losses or potential gains on the existing security investments of banks. For instance, one could be concerned that trading banks reduce credit supply primarily due to their reluctance to sell securities to preserve book equity. We find that the coefficient on unrealized losses or gains is insignificant. Interestingly, in columns 5 and 6, we do not find that central bank borrowing supports credit supply, different from the results on trading behavior. In column 7, we examine the effect of recapitalization dummy on lending. We find that banks that get recapitalized lend less, in contrast to their trading behavior reported earlier, where these banks buy more of the securities that had a large price drop. We also examine the interactions of gains and public borrowing with trading bank and Landesbank dummies and do not find significant results (see Appendix Table A9).

A concern could be that trading banks reduce credit supply because of differential risktaking. To analyze the incremental risk in loans, we also examine the interaction of trading banks with future loan defaults (over the following two years). Column 8 reports the results from this estimation. We find that the coefficient on the interaction term of trading banks with future

\footnotetext{
${ }^{30}$ Note that we assume that securities markets and lending markets have some degree of segmentation (i.e., loan rates do not adjust immediately to being equal to security returns). This seems plausible during a crisis when there are large dislocations in asset markets. Note that it is also difficult for banks to increase interest rates substantially to compensate for the returns from security investments due to the risk of adverse selection and moral hazard that arise in lending (Stiglitz and Weiss, 1981).
} 
default is not significantly different from zero. ${ }^{31}$ These results suggest that trading banks did not differentially take on more risk in loans. ${ }^{32}$

One could still be concerned about borrowers matching with banks differentially. To examine this issue, we compare the estimated coefficients on trading bank dummy with and without the inclusion of borrower*time fixed effects (column 1 versus column 2). We find that the estimated coefficients are not statistically different from each other. However, the noninclusion of borrower*time fixed effects in column 1 substantially reduces the R-squared from $44.1 \%$ to $0.8 \%$. The finding that the coefficients are not statistically different from each other but that there is a substantial, large change in R-squared suggests that our main bank variable coefficients are exogenous to a large set of unobserved and observed, time-varying borrower fundamentals (see, Altonji, Elder, and Taber, 2005), thereby suggesting that the covariance between trading banks (supply) and unobserved firm fundamentals (demand) is negligible. Therefore, the results suggest that differential borrower demand arising due to unobserved matching between banks and borrowers is unlikely to be the driver of the results. Thus, one can interpret the results at the firm level (in column 9) where we cannot control for borrower*time fixed effects as driven by credit availability.

All in all, we find that trading banks cut on their supply of credit. However, firms that were borrowing from these banks could substitute with other banks. In column 9, we examine this issue. For instance, imagine a firm that had two banking relationships before the crisis, one with a trading bank and the other with a non-trading bank. Can the firm increase the credit from the non-trading bank (or from new relationships) and not suffer any overall restriction of credit? To examine this issue, we first create the fraction of borrowing of a firm from banks with trading expertise before the crisis (2007:Q2). This variable does not vary at the firm level and therefore we cannot introduce firm fixed effects (credit change is at the firm level). In column 9, we find

\footnotetext{
${ }^{31}$ Loan defaults without the interaction is absorbed by the firm*time fixed effects, as we have loan defaults at the firm-time level.

${ }^{32}$ The results are also robust to double clustering at the bank and borrower level. In addition, one could still be concerned about borrowers matching with banks differentially. To analyze this differential matching channel, we ran the estimation including bank(lender)*firm(borrower) fixed effects. We find that trading banks with a higher level of capital also decrease supply of credit relative to other banks. See this robustness and others in the previous version of the draft. Moreover, not reported, to make sure that the results are not driven by procyclicality of lending that could arise due to Basel II, we estimate the results excluding these loans and find similar results to those reported earlier; also, similarly as in trading, Tier 1 capital buffer is insignificant in explaining credit supply; finally, we also estimated the regressions controlling for the loan exposures of banks to different business sectors, and the results remain unchanged.
} 
that for firms with a higher pre-crisis fraction of borrowing from trading banks, the total change in credit is negative and significant; therefore, the credit reduction is binding at the firm level. In addition, we also construct other measures of a firms' exposure to trading banks (such as higher than $50 \%$ of the firms total borrowing, or weighted averages based on the capital level of trading banks) and find similar results (not reported).

To further examine whether firms that were borrowing from these (trading) banks could substitute with market debt-based financing, we collected data on corporate debt issuances over the sample period. We find that there are issuances of corporate debt by some (generally very large) firms during the crisis. Thus some firms, which have access to bond markets, are being able to at least partly substitute bank-based finance with market-based finance. ${ }^{33}$ However, the number of firms that are able to access bond financing is small and also the corporate debt volumes are small (relative to the firms that access bank financing). ${ }^{34}$ To formally test for substitution, in Table 9, column 10, we analyze in a regression framework whether a firm increases its corporate debt (issuance) in the crisis if it depended more on bank credit from banks with higher trading expertise (which reduce bank credit in the crisis). We find that this is indeed the case, the coefficient is positive and statistically significant, however the economic magnitude is small. Moreover, in column 11, we find that reduction in bank credit is not fully compensated by market-based finance. We find that firms that relied more on bank credit from trading banks experience a reduction in overall debt from banks and markets in the crisis. That is, we do not find that firms compensate the reduction in bank credit by market-based finance (note that the coefficient of column 9 on change in bank credit and the coefficient of column 11, change in overall firm debt including bank credit and market debt, has an almost identical coefficient). Finally, in Appendix Table 10 of the paper, we examine whether there is an association between change in bank credit and volume of corporate debt issuances. Not surprisingly, given the previous results, we do not find any significant association.

These results suggest that firms that were borrowing more from banks with higher trading expertise faced a higher reduction in total credit, which was binding. Given that Germany is a

\footnotetext{
${ }^{33}$ See Adrian, Colla, and Shin (2013) for evidence in the U.S context that borrowers are substituting from bankbased finance to market-based finance during the crisis.

${ }^{34}$ Even during normal times the number of firms accessing corporate debt markets in Germany is low as compared to a country like USA, thus primarily the set of firms that access bond financing is limited, as bank credit is the main source of financing for German firms (see also Allen, Chui and Maddaloni, 2004).
} 
bank-dominated system and given our results on market-based finance, our results suggest strong negative real effects. Furthermore, the banks that we classify as trading banks constitute nearly $50 \%$ of the total credit in Germany, thus the results suggest important effects in terms of credit supply at the macro level.

\subsection{Further robustness}

While the results above show that in the crisis period, banks with higher trading expertise (especially the ones with higher capital) increase their investments in securities and reduce the supply of credit to non-financial firms, analysis of the pre-crisis and the post-crisis periods can help further shed light on the main mechanism. The main channel highlighted earlier relies on a large shock to securities markets (returns) during the crisis and the presence of bank funding constraints. This also suggests that in periods when there are no large shocks to securities markets or bank funding constraints are not binding, one would not expect to find similar results as in the crisis period. Note that even if returns from investing in securities markets are high, if the bank funding constraints are less binding, the spillover effects of higher investment in securities on credit supply should be lower or non-existent.

In Table 10, Panel A, we examine the investment in securities in the pre-crisis and postcrisis periods. While banks with higher trading expertise buy and sell more securities in general across all the periods (see summary statistics in Table 1), we do not find that they substantially change the proportion of investments in securities in the pre-crisis and post-crisis periods (columns 1 and 2 of Table 10, Panel A). As compared to crisis, the fall in prices of securities is not that pronounced even during the post-crisis period (that has the Euro sovereign debt crisis). In the post-crisis period, we see that there is some volatility in securities markets, especially around the initial Greek crisis and also in 2011:Q2. It is interesting to note that trading banks buy into Greek bonds at the time when their spreads are widening but before the worst moments of the Greek crisis (see Fig. A1 in the Appendix). ${ }^{35}$ However, as Table 10, Panel B shows, we do not find a significant reduction in credit supply relative to other banks (also not significantly different from the coefficient in the pre-crisis period). In addition, the coefficient on capital for trading banks is not significant (columns 1 to 4). There are also no significant differences in future

\footnotetext{
${ }^{35}$ When we examine these particular quarters, we again see that there is a significant increase in securities holdings as a fraction of total assets for trading banks as compared to other banks. See the spike in total securities for trading banks in Fig. 3 for mid-2010.
} 
default rates in these periods between banks with trading expertise relative to other banks (columns 2 and 4). Note that, as compared to the crisis period, when most banks report capital and wholesale funding constraints as important factors affecting business operations, this is substantially less the case during the post-crisis period, especially in Germany (see Bundesbank and the ECB survey of Euro area banks). ${ }^{36}$ Also, banks' equity capital base is higher, at 5.4\%, in the post-crisis period as compared to $4.8 \%$ in the crisis (see summary statistics in Table 1), thus also suggesting that capital constraints are less binding.

A crucial quantitative question is, what are the ex-post returns that banks with higher trading expertise obtain in the crisis? To do this, we examine the average returns on a portfolio of securities formed by mimicking the investments of banks with higher trading expertise. We create a portfolio by selecting the same securities (that had fallen in price) and the same timing of investments. Using this method, we find that the realized returns (annualized) on investments made after the failure of Lehman Brothers are approximately 12.5\% over the subsequent quarters (see Figure 5). The realized return (annualized) on investments in securities with maturity of more than five years is higher at approximately $21 \%$ and for non-triple-A is at $14 \%{ }^{37}$

While the results above are consistent with banks with higher trading expertise increasing their investment in securities during the crisis to profit from trading opportunities, thereby reducing the supply of credit, we examine several other alternative explanations. The first channel is through liquidity preference. That is, trading banks have a preference for liquid assets like securities as compared to loans. Based on this explanation, one should expect trading banks to buy more of securities that are liquid. However, this explanation is difficult to reconcile with the finding that trading banks buy more of securities that are long-term rather than short-term and securities with lower ratings as compared to triple-A securities and securities that had large price drops. For example, trading banks invest more in Greek sovereign debt exactly at the point when the spreads widen, which is difficult to reconcile with a purely liquidity preference based explanation. Note that liquidity preference by itself is not inconsistent with the banks trying to exploit trading opportunities in securities markets. For instance, several theoretical papers (Allen

\footnotetext{
${ }^{36}$ Though the bank liquidity problems can be solved with the ECB liquidity assistance, bank capital problems are not eliminated by ECB liquidity assistance. See Bernanke (1983) and Freixas and Rochet (2008) for discussion on why bank capital is costly, especially in crisis times. Admati and Hellwig (2013) question part of these costs.

${ }^{37}$ We assume that the securities are sold in 2009:Q4. We also estimated the realized returns using the actual buying and selling behavior of banks. For the 2009:Q2, we find that returns are approximately 11.9\% (annualized).
} 
and Gale, 1998; Diamond and Rajan, 2011; Acharya, Shin, and Yorulmazer, 2011) argue that banks will hoard on liquidity rather than lock funds into loans, in anticipation of making high returns from acquiring securities in fire sales. ${ }^{38}$

We also investigate whether gains from trading act as a hedge against lending income. The idea being that trading banks expect future interest rates to be low, which in turn reduces their income from lending. Therefore, trading banks may invest in securities whose prices rise with lower interest rates, thus acting as a hedge against drop in lending income. To examine this channel, we use the data from 1998 on lending income and trading income at the bank level and find that they are positively correlated. This suggests that trading income from securities does not provide a hedge against lending income declines. In addition, while highly rated securities might provide a hedge (e.g., holding German sovereign bonds), this is not generally the case for securities with long-term maturity and lower ratings. Thus it is difficult to explain the increase in investments in securities that had a larger price drop (especially in lower-rated and long-term maturity) and a reduction in credit supply purely by a hedging-based explanation. The example that we discussed in the Introduction on the JP Morgan bond is illustrative of the trading opportunities for banks with higher trading expertise to obtain high returns on investments.

Another possible channel is that banks that have higher trading expertise buy more of securities that had a larger drop in price due to their market-making activities and hence cut back on credit. While this explanation again suggests that banks reduce their credit supply to profit from income from market making, the channel is different from directly investing for trading purposes. To examine this channel, for a subset of securities we obtained information on the market-making bank. In the Appendix Table A3, we examine the buying and selling behavior for securities that had large price drops excluding for each bank the securities where the bank is a market maker. We find that the trading bank dummy remains significant and also the estimated magnitude is similar to those estimated before. This suggests that the buying behavior of banks is mainly driven by proprietary trading rather than a result of market making. Furthermore, we also find that the estimated gains from investments in securities that had a larger drop in price are positively correlated with trading income and net profits that banks report. This suggests that banks directly benefit from their trading activities and that these investments are not simply hedges or arise due to market-making activities.

\footnotetext{
${ }^{38}$ See Allen and Carletti (2008) for a recent overview of the issues.
} 
The security analysis reported earlier does not include securities that do not have a traded market price. To examine whether the trading behavior of banks differs for this type of assets (proxy for level 3 assets), we separately estimate the specification reported in Table 5 for these securities. We again find similar results to those reported earlier (Appendix Table A4). Trading banks and Landesbanks again buy more of these securities. Furthermore, we also find that trading banks with higher capital levels buy more. This suggests that the results are not driven by differential accounting treatment for certain classes of securities.

Finally, one could be concerned that autocorrelation of the error terms might impact significance of the results reported in the securities analysis. To examine the robustness of the results, we estimate the buying behavior of banks separately in each of the quarters (Appendix Table A6). Given that this analysis is at the cross-sectional level (each quarter), autocorrelation over time in error terms arising due to persistence in buying behavior is not a concern. We again find that in most of the quarters in the crisis, trading banks buy more of securities that had large price drops. We also introduced the lag of buys in the specification reported in Table 3 and find the coefficient on the lagged term to be close to 0.02, which suggests small persistence in buying behavior. Furthermore the estimated coefficients on the trading bank and Landesbank dummies are similar in magnitude and significant (not reported).

In sum, the results are most consistent with banks that have higher trading expertise increasing their investments in securities to profit from the trading opportunities and withdrawing funds from lending.

\section{Conclusion}

We analyze security-trading activities of banks during a crisis and the associated spillovers to the supply of credit. Empirical analysis has been elusive due to the lack of comprehensive securities register for banks. We overcome this problem by using a proprietary dataset of the investments of banks at the security-level for each bank in each quarter for the period between 2005 and 2012 in conjunction with the credit register from Germany.

We find that banks with higher trading expertise increase their overall investments in securities during a crisis, especially in securities that had a larger drop in price. Furthermore, this effect is more pronounced for banks with a higher level of capital. Interestingly, the overall expost returns are about $12.5 \%$ annualized for trading-expertise banks in the crisis. In contrast to the 
behavior in securities markets, banks with higher trading expertise reduce their overall supply of credit in crisis times. The estimated magnitude of decrease in lending is approximately 5 percentage points. The reduction in credit supply is more pronounced for trading banks with higher capital, and moreover, we also find that the credit reduction is binding at the firm level. Given that credit from banks with trading expertise constitutes a large fraction of overall credit in Germany, and that Germany is a bank-dominated economy, the results suggest a significant impact on the availability of credit to firms during the crisis at the macro level. Finally, our results suggest that central bank liquidity and direct or indirect government subsidies mainly support trading activities, but not the supply of credit to the real sector.

Given the results, a question that naturally arises is whether banks should engage in securities trading. While there has been a move by some regulators to limit proprietary trading activities of banks, the welfare consequences are not clear. Our results suggest that - during a crisis - securities trading by banks can crowd out lending and also that government subsidies mainly help by supporting trading in riskier securities rather than supporting lending to the real sector. However, the results do not necessarily imply that buying of securities by trading banks is socially undesirable. For instance, the price support to securities markets by trading banks might have positively affected the aggregate wealth of agents in the economy, which in turn could have positive effects on the real economy via aggregate consumption and hence aggregate employment. Thus, one needs to consider the benefits of price support to securities markets and the costs associated with reduction in credit supply and the potential increase in systemic risk to draw welfare implications of security trading by banks on the real economy. ${ }^{39}$ This quantitative comparison is beyond the scope of this paper and is an interesting avenue for future research. The lingering questions that remain are, absent banks, would other intermediaries/governments be able to absorb the risk and provide liquidity to the securities markets?

\footnotetext{
${ }^{39}$ See Brunnermeier et al. (2012), Saunders et al., (2014), and Freixas et al. (2015) for analyses of systemic risk implications of bank trading activities.
} 


\section{References}

Acharya, V., Steffen, S., 2015. The greatest carry trade ever? Understanding Eurozone bank risks. Journal of Financial Economics 115, 215-236.

Acharya, V., Shin, H. S., Yorulmazer, T., 2011. Crisis resolution and bank liquidity. Review of Financial Studies 24, 2166-2205.

Acharya, V., Shin, H. S., Yorulmazer, T., 2013. A theory of arbitrage capital. Review of Corporate Financial Studies 2, 62-97.

Admati, A., Hellwig, M., 2013. The Bankers’ New Clothes: What’s Wrong with Banking and What to do about it. Princeton University Press, Princeton.

Adrian, T., Shin, H. S., 2010. Liquidity and leverage. Journal of Financial Intermediation 19, 418-437.

Adrian, T., Colla, P., Shin, H. S., 2013. Which financial frictions? Parsing the evidence from the financial crisis of 2007 to 2009. NBER Macroeconomics Annual, University of Chicago Press, 27, 159-214.

Allen, F., Gale, D., 1994. Liquidity Preference, Market Participation and Asset Price Volatility, American Economic Review 84(4): 933-55.

Allen, F., Gale, D., 1998. Optimal financial crises. Journal of Finance 53, 1245-1284.

Allen, F., Gale, D., 2005. From cash-in-the-market pricing to financial fragility. Journal of the European Economic Association 3, 535-46.

Allen, F., Chui, M., Maddaloni, A., 2004. Financial systems in Europe, the USA and Asia. Oxford Review of Economic Policy 20, 490-508.

Allen, F., Carletti, E., 2008. The role of liquidity in financial crises. Jackson Hole Conference Proceedings, Federal Reserve Bank of Kansas City, 279-412.

Altonji, J. G., Elder, T. E., Taber, C. R., 2005. Selection on observed and unobserved variables: assessing the effectiveness of catholic schools. Journal of Political Economy 113, 151184.

Bernanke, B., 1983. Nonmonetary effects of the financial crisis in propagation of the 
Great Depression. American Economic Review 73, 257-76.

Brunnermeier, M., Pedersen, L., 2009. Market liquidity and funding liquidity. Review of Financial Studies 22, 2201-2238.

Brunnermeier, M., Sannikov, Y., 2014. A macroeconomic model of the financial sector, American Economic Review 104, 379-421.

Brunnermeier, M., Dong, G., Palia, D., 2012. Banks’ non-interest income and systemic risk. Unpublished working paper.

Dang, T. V., Gorton, G., Holmström, B., 2013. Ignorance, debt and financial crises. Unpublished working Paper.

Diamond, D., Dybvig, P., 1983. Bank runs, deposit insurance and liquidity. Journal of Political Economy 99, 401-19.

Diamond, D., Rajan, R., 2001. Liquidity risk, liquidity creation and financial fragility: a theory of banking. Journal of Political Economy 109, 287-327.

Diamond D., Rajan, R., 2011. Fear of fire sales, illiquidity seeking, and credit freezes. Quarterly Journal of Economics 126, 557-591.

Drechsler, I., Drechsel, T., Marques, D., Schnabl, P., 2014. Who borrows from the lender of last resort? Journal of Finance (forthcoming).

Duffie, D., 2010. Asset price dynamics with slow-moving capital. Journal of Finance 65, 1237-1267.

Freixas, X., Rochet, J.-C., 2008. Microeconomics of Banking, $2^{\text {nd }}$ edition. MIT Press, Cambridge, MA.

Freixas, X., Laeven, L., Peydró, J.-L., 2015. Systemic Risk, Crises and Macroprudential Policy. MIT Press, Cambridge MA.

Gennaioli, N., Shleifer, A., Vishny, R., 2013. A model of shadow banking. Journal of Finance 68, 1331-1363.

Georgescu, O., Laux, C., 2013. Financial reporting, financial regulation, and financial stability: evidence from German bank failures in 2007. Unplublished working paper. 
Gorton, G., Metrick, A., 2012. Securitized banking and the run on repo. Journal of Financial Economics 104, 425-451.

Gromb, D., Vayanos, D., 2002. Equilibrium and welfare in markets with financially constrained arbitrageurs. Journal of Financial Economics 66, 361-407.

Hanson, S., Shleifer, A., Stein, J., Vishny, R., 2015. Banks as patient fixed income investors. Journal of Financial Economics 117, 449-469.

He, Z., Krishnamurthy, A., 2012. A model of capital and crises. Review of Economic Studies 79, 735-777.

He, Zhiguo, Krishnamurthy, A., 2013. Intermediary asset pricing. American Economic Review 103, 732-770.

He, Z., Khang, I. G., Krishnamurthy, A., 2010. Balance sheet adjustments during the 2008 crisis. IMF Economic Review 58, 118-156.

Holmstrom, B., Tirole, J., 1998. Private and public supply of liquidity. Journal of Political Economy 106, 1-39.

Ivashina, V., Scharfstein, D., 2010. Bank lending during the financial crisis of 2008. Journal of Financial Economics 97, 319-338.

Iyer, R., Peydró, J.-L., da-Rocha-Lopes, S., Schoar, A., 2014. Interbank liquidity crunch and the firm liquidity crunch: evidence from the 2007-2009 crisis. Review of Financial Studies 27, 347-372.

Jiménez, G., Ongena, S., Peydró, J.-L., Saurina, J., 2012. Credit supply and monetary policy: identifying the bank balance-sheet channel with loan applications. American Economic Review 102, 2301-2326.

Jiménez, G., Ongena, S., Peydró, J.-L., Saurina, J., 2014. Hazardous times for monetary policy: what do 23 million loans say about the impact of monetary policy on credit risk-taking? Econometrica 82, 463-505.

Kashyap A., Rajan, R., Stein, J., 2002. Banks as liquidity providers: an explanation for the co-existence of lending and deposit-taking. Journal of Finance 57, 33-73. 
Khwaja, A. I., Mian, A., 2008. Tracing the impact of bank liquidity shocks: evidence form an emerging market. American Economic Review 98, 1413-42.

Langfield, S., Pagano, M., 2014. Bank bias in Europe: effects on systemic risk and growth. Unpublished working paper.

Laux, C., Leuz, C., 2010. Did fair-value accounting contribute to the financial crisis? Journal of Economic Perspectives 24, 93-118.

Saunders, A., Schmid, M., Walter, I., 2014. Non-interest income and bank performance: is banks’ increased reliance on non-interest income bad? Unpublished working paper.

Shleifer, A., Vishny, R., 1992. Liquidation values and debt capacity: a market equilibrium approach. Journal of Finance 47, 1343-1366.

Shleifer, A., Vishny, R., 1997. The limits of arbitrage. Journal of Finance 52, 35-55.

Shleifer, A., Vishny, R., 2010. Unstable banking. Journal of Financial Economics 97, 306-318.

Stein, J., 2013. The fire-sales problem and securities financing transactions. Speech by Governor Jeremy C. Stein at the Federal Reserve Bank of New York during the Workshop on Fire Sales as a Driver of Systemic Risk in Triparty Repo and other Secured Funding Markets, New York, October 4, 2013.

Stiglitz, J., Weiss, A., 1981. Credit rationing in markets with imperfect information. American Economic Review 71, 393-410.

Uhlig, H., 2010. A model of systemic bank run. Journal of Monetary Economics 57, 7896.

Xiong, W., 2001. Convergence trading with wealth effects: an amplification mechanism in financial markets. Journal of Financial Economics 62, 247-92. 


\section{FIGURES}

FIGURE 2:

SECURITY PRICES

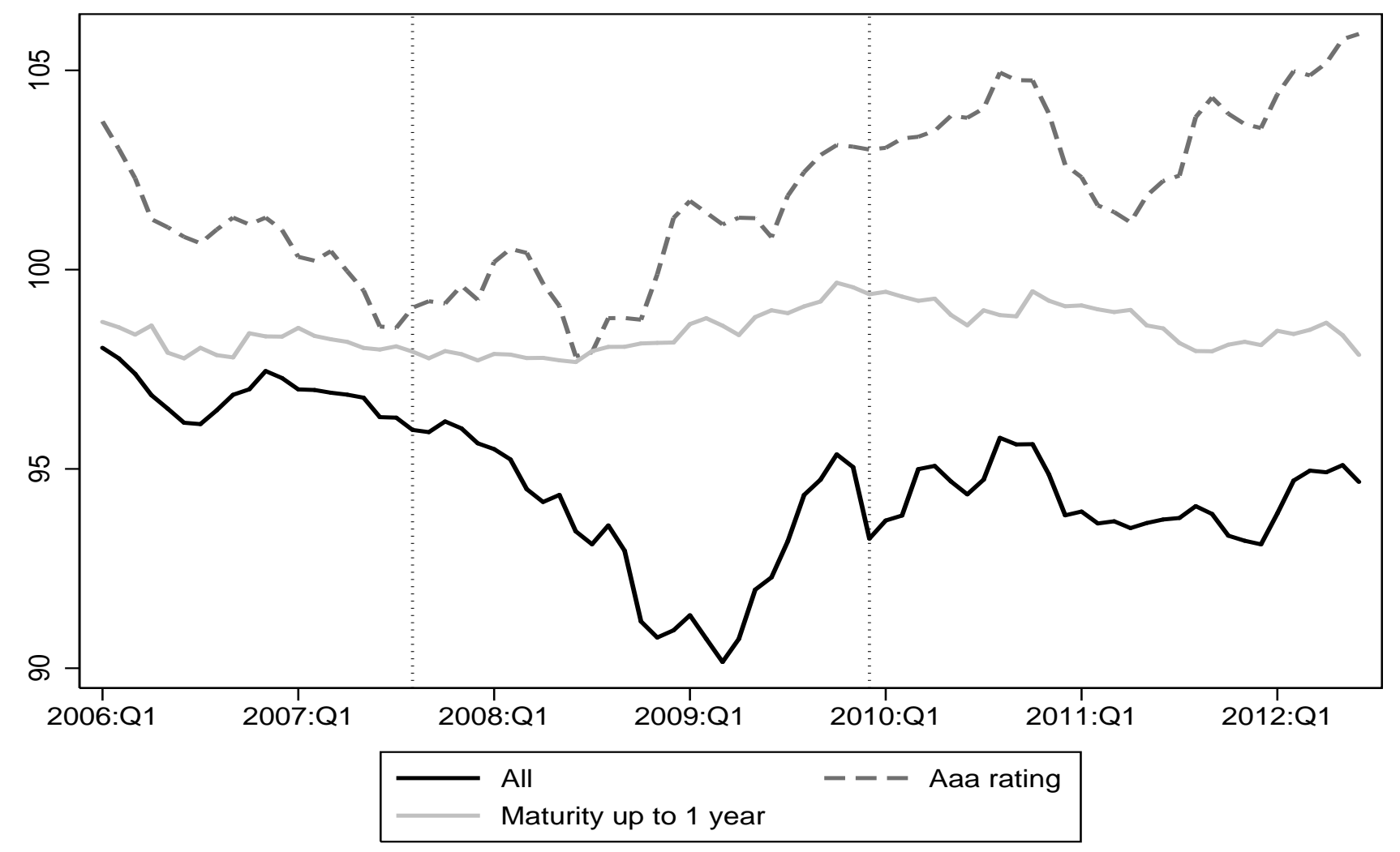

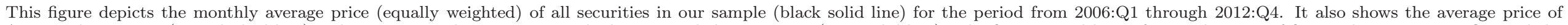

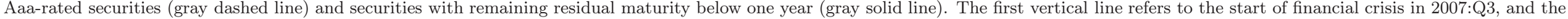
second vertical line denotes 2009:Q4, the end of the crisis in Germany. 
FIGURE 3:

SeCurities Holdings

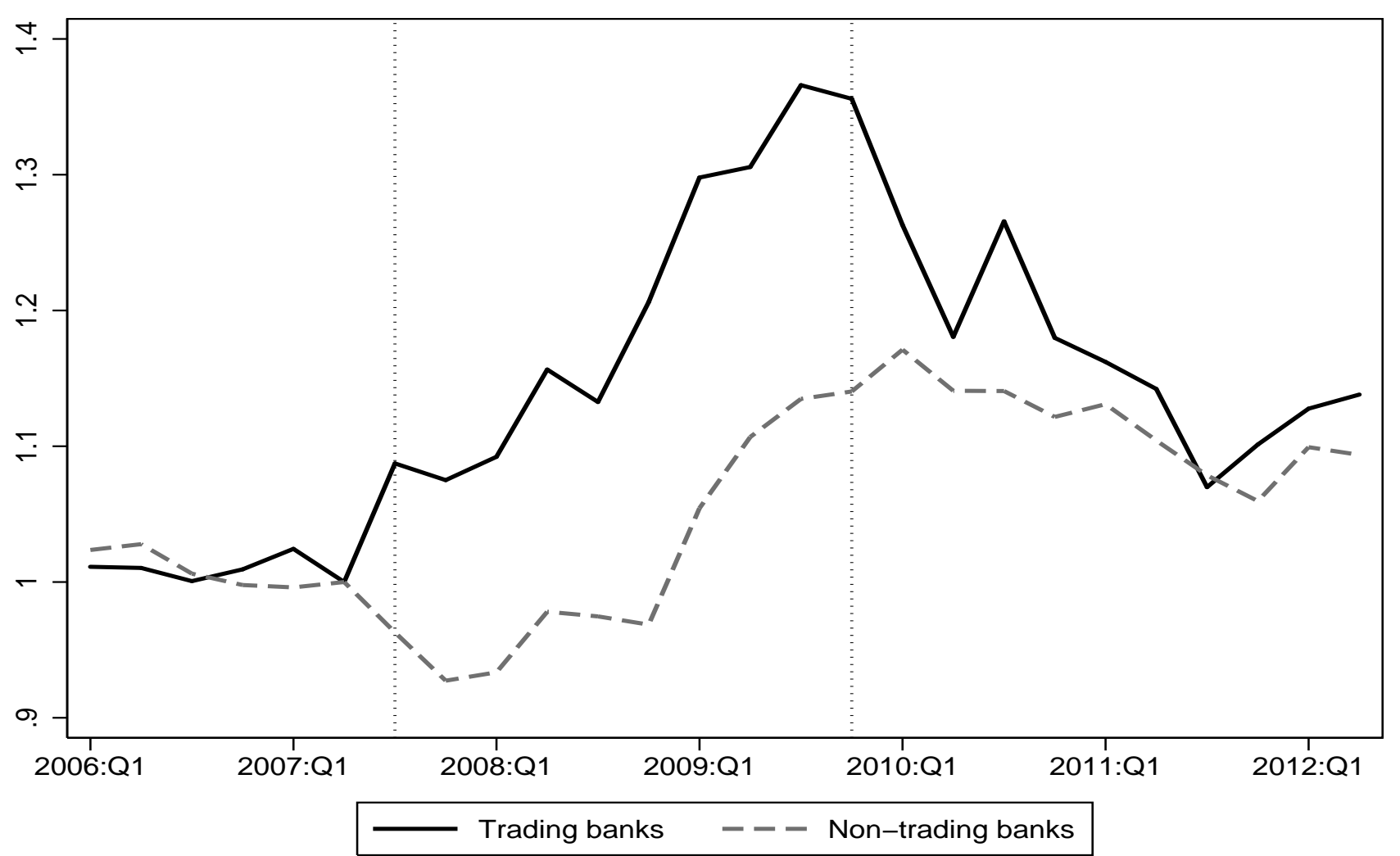

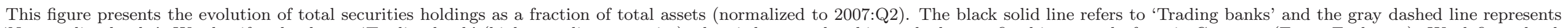

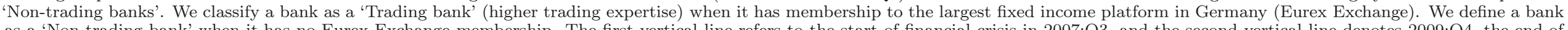

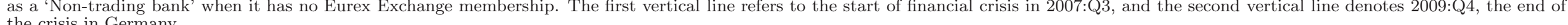


FIGURE 4:

\section{Credit Growth}

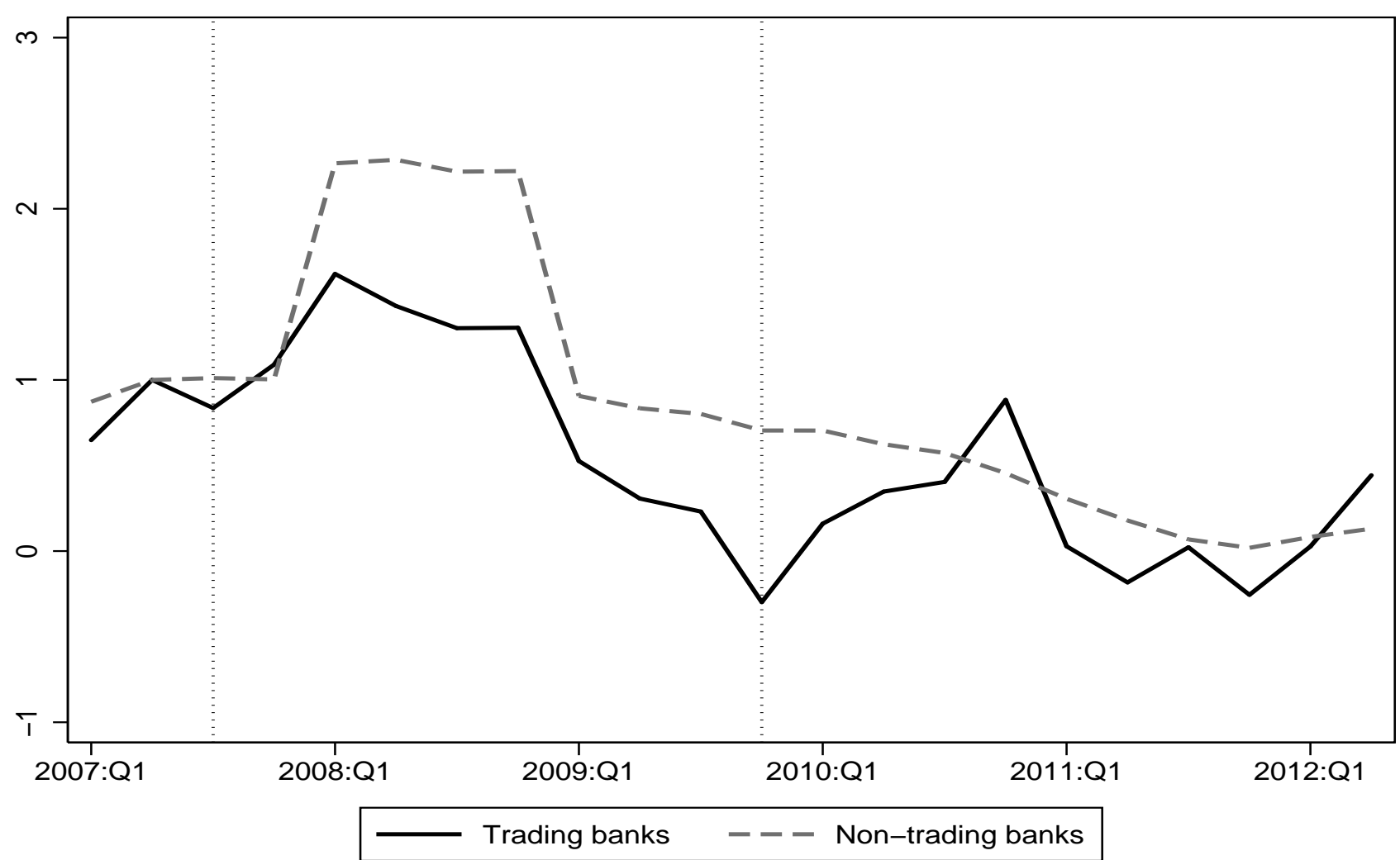

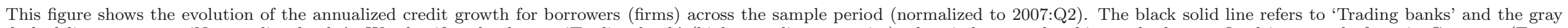

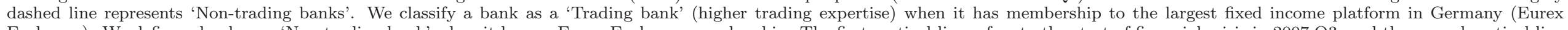

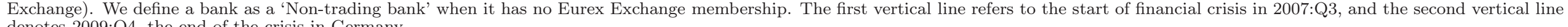


FIGURE 5:

Returns FROM SECURITy InVEstments

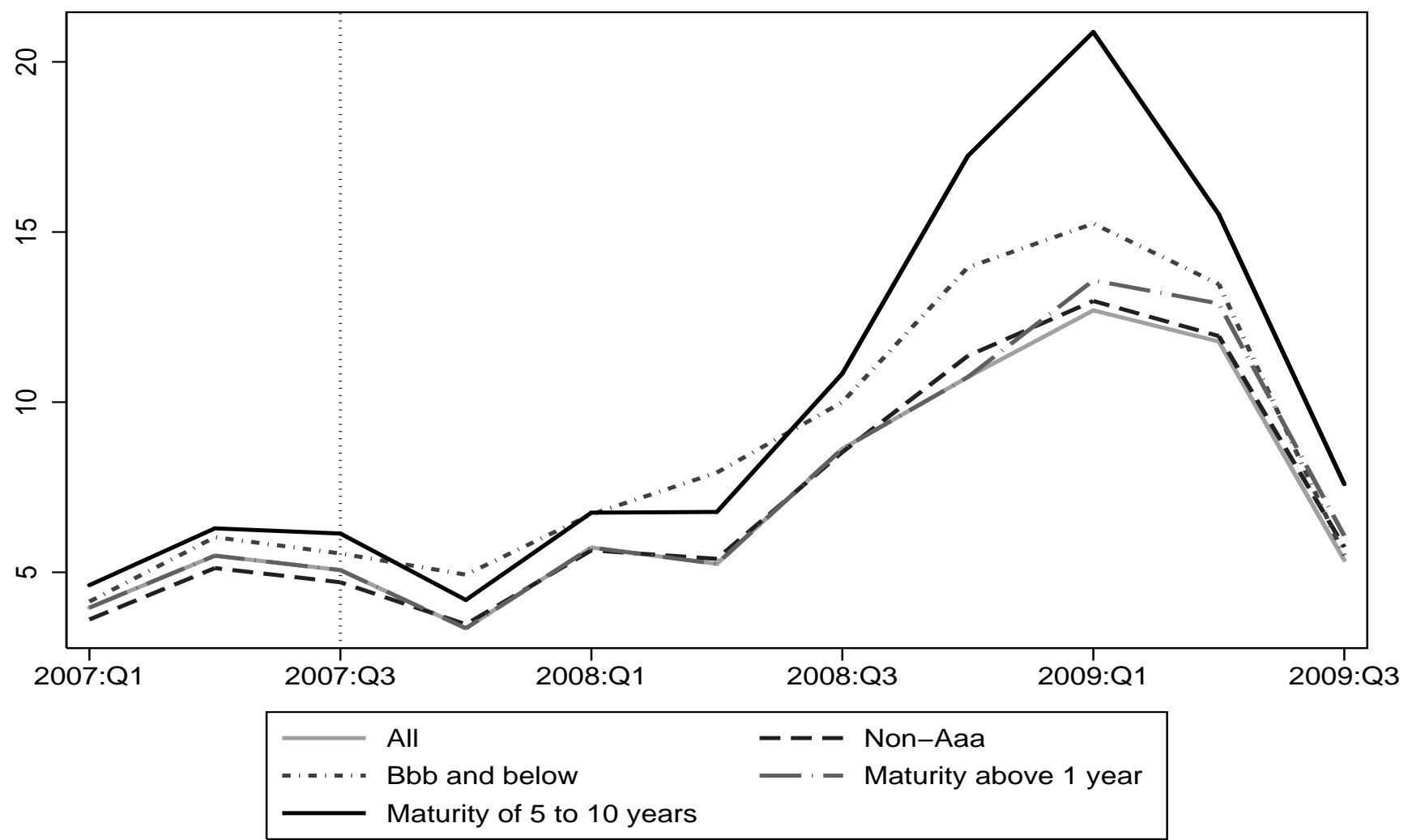

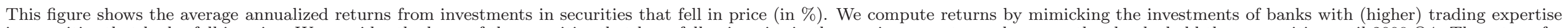

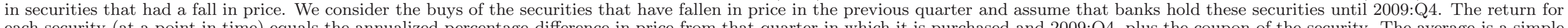

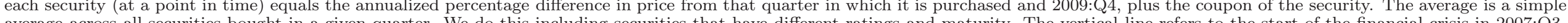




\section{TABLES}

TABLE 1:

SUMMARY STATISTICS

Panel A: Trading banks

Securities holdings/TA

Aaa securities

Domestic securities

Long-term securities

Sovereign securities

Off-balance sheet securities/TA

Central bank borrowing/TA

Buys/TA

Sells/TA

Loans/TA

Capital/TA

Size

\begin{tabular}{|c|c|c|c|c|c|c|c|c|}
\hline \multicolumn{3}{|c|}{ Pre-crisis } & \multicolumn{3}{|c|}{ Crisis } & \multicolumn{3}{|c|}{ Post-crisis } \\
\hline Mean & Std. & Obs. & Mean & Std. & Obs. & Mean & Std. & Obs. \\
\hline 18.78 & 11.69 & 150 & 22.78 & 13.99 & 296 & 22.15 & 12.60 & 353 \\
\hline 58.03 & 61.01 & 150 & 50.56 & 26.10 & 296 & 55.63 & 25.84 & 353 \\
\hline 64.09 & 27.72 & 150 & 57.60 & 30.24 & 296 & 48.75 & 53.31 & 353 \\
\hline 71.73 & 33.73 & 150 & 77.24 & 23.23 & 296 & 86.41 & 41.37 & 353 \\
\hline 33.04 & 43.13 & 150 & 30.30 & 32.37 & 296 & 41.87 & 43.88 & 353 \\
\hline 3.91 & 5.27 & 150 & 3.00 & 4.35 & 296 & 2.45 & 3.46 & 353 \\
\hline 2.24 & 3.25 & 150 & 2.82 & 4.01 & 296 & 0.85 & 1.89 & 353 \\
\hline 3.55 & 3.49 & 150 & 3.94 & 4.61 & 296 & 2.87 & 2.99 & 353 \\
\hline 1.72 & 2.16 & 150 & 1.15 & 1.53 & 296 & 1.26 & 1.62 & 353 \\
\hline 66.50 & 12.79 & 150 & 63.89 & 15.33 & 296 & 60.71 & 14.89 & 353 \\
\hline 4.80 & 3.88 & 150 & 4.81 & 3.98 & 296 & 5.44 & 5.48 & 353 \\
\hline 16.65 & 1.91 & 150 & 16.80 & 1.88 & 296 & 16.85 & 1.94 & 353 \\
\hline
\end{tabular}

Panel B: Non-trading BANKS

\begin{tabular}{|c|c|c|c|c|c|c|c|c|c|}
\hline & \multicolumn{3}{|c|}{ Pre-crisis } & \multicolumn{3}{|c|}{ Crisis } & \multicolumn{3}{|c|}{ Post-crisis } \\
\hline & Mean & Std. & Obs. & Mean & Std. & Obs. & Mean & Std. & Obs. \\
\hline Securities holdings/TA & 18.40 & 10.99 & 2,563 & 18.67 & 10.09 & 5,083 & 20.34 & 10.64 & 6,098 \\
\hline Aaa securities & 41.00 & 25.51 & 2,563 & 39.14 & 27.17 & 5,083 & 39.44 & 24.02 & 6,098 \\
\hline Domestic securities & 78.43 & 21.82 & 2,563 & 71.73 & 25.29 & 5,083 & 66.59 & 27.09 & 6,098 \\
\hline Long-term securities & 77.82 & 18.46 & 2,563 & 77.28 & 21.59 & 5,083 & 83.41 & 23.36 & 6,098 \\
\hline Sovereign securities & 18.74 & 19.42 & 2,563 & 16.05 & 18.85 & 5,083 & 19.44 & 19.04 & 6,098 \\
\hline Off-balance sheet securities/TA & 1.10 & 1.60 & 2,563 & 1.22 & 1.84 & 5,083 & 1.25 & 1.47 & 6,098 \\
\hline Central bank borrowing/TA & 1.33 & 2.90 & 2,563 & 2.01 & 3.48 & 5,083 & 1.11 & 2.24 & 6,098 \\
\hline Buys/TA & 1.96 & 4.14 & 2,563 & 2.23 & 2.60 & 5,083 & 1.53 & 1.78 & 6,098 \\
\hline Sells/TA & 0.76 & 3.70 & 2,563 & 0.38 & 0.84 & 5,083 & 0.27 & 0.69 & 6,098 \\
\hline Loans/TA & 69.24 & 11.85 & 2,563 & 69.62 & 11.32 & 5,083 & 68.24 & 12.13 & 6,098 \\
\hline Capital/TA & 5.04 & 1.32 & 2,563 & 5.04 & 1.34 & 5,083 & 5.19 & 1.35 & 6,098 \\
\hline Size & 14.53 & 1.00 & 2,563 & 14.63 & 0.99 & 5,083 & 14.73 & 0.95 & 6,098 \\
\hline
\end{tabular}

This table reports the summary statistics of the variables used in the paper, across three periods. We define 'Pre-crisis' (2006:Q1 - 2007:Q2), 'Crisis' (2007:Q3 - 2009:Q4), and 'Post-crisis' (2010:Q1 - 2012:Q4). Panel A reports the summary statistics for 'Trading banks'. Panel B reports the summary statistics for 'Non-trading banks'. We classify a bank as a 'Trading bank' (higher trading expertise) when it has membership to the largest fixed income platform in Germany (Eurex Exchange). 'Aaa securities' measures the total investment in Aaa-rated securities as a fraction of the total investment in securities (in \%). 'Domestic securities' measures the total investment in securities with German issuer as a fraction of total investment in securities (in \%). 'Long-term securities' measures the total investment in securities with residual maturity higher than one year as a fraction of the total investment of securities (in \%). 'Sovereign securities' measures the total investment in securities issued by sovereigns as a fraction of the total investment in securities (in \%). 'Capital/TA' measures the book value of equity as a fraction of total assets (in \%). 'Size' refers to the logarithm of total assets (in thousand Euros). The definition of the other variables can be found in Table A10. The summary statistics for Landesbanks are reported separately in Table A1. 
TABLE 1:

SUMMARY STATISTICS (CONT'D)

Panel C: Trading banks and Non-trading banks

Crisis subsample: 2007:Q3 - 2009:Q1

\begin{tabular}{|c|c|c|c|c|c|c|c|c|c|c|}
\hline & \multicolumn{5}{|c|}{ Trading BANKS } & \multicolumn{5}{|c|}{ NON-TRADING BANKS } \\
\hline & Mean & Std. & $\mathrm{p} 10 \%$ & p90\% & Obs. & Mean & Std. & $\mathrm{p} 10 \%$ & $\mathrm{p} 90 \%$ & Obs. \\
\hline Gains on holdings & -0.31 & 0.39 & -0.75 & -0.00 & 209 & -0.25 & 0.33 & -0.64 & -0.00 & 3,568 \\
\hline Gains on pre-crisis holdings & -0.21 & 0.30 & -0.63 & 0.00 & 209 & -0.14 & 0.23 & -0.38 & 0.00 & 3,568 \\
\hline
\end{tabular}

This table reports the summary statistics of further variables used in the paper, for a subsample of the 'Crisis' period (2007:Q3 - 2009:Q1). We classify a bank as a 'Trading bank' (higher trading expertise) when it has membership to the largest fixed income platform in Germany (Eurex Exchange). We define a bank as a 'Non-trading bank' when it has no Eurex Exchange membership. 'Gains on holdings' measures the (unrealized) gains/losses on all securities in the bank's portfolio as a fraction of total assets (in \%). 'Gains on pre-crisis holdings' measures the (unrealized) gains/losses on all securities in the bank's pre-crisis portfolio with maturing dates after 2009:Q4 as a fraction of total assets (in \%). The summary statistics for the 'Pre-crisis' (2006:Q1 - 2007:Q2), 'Crisis' (2007:Q3 - 2009:Q4), and 'Post-crisis' (2010:Q1 - 2012:Q4) are reported in Table A1. 
TABle 2 PANel A:

TRADING BEHAVIOR DURING THE CRISIS

Dependent variable:

Trading bank $b$

Landesbank $_{b}$

Bank controls

Security*Time fixed effects

Time fixed effects

Observations

R-squared
Buys

\begin{tabular}{|c|c|}
\hline$\Delta \mathrm{Sec} / \mathrm{TA}$ & Buys \\
\hline (1) & (2) \\
\hline $\begin{array}{c}0.444^{* *} \\
(0.153)\end{array}$ & $\begin{array}{c}2.007^{* * * *} \\
(0.603)\end{array}$ \\
\hline
\end{tabular}

0.159

$(0.115)$

$\begin{array}{r}1.665^{* *} \\ (0.765) \\ \hline\end{array}$

$\mathrm{Y}$

Y

5,379

5,379
0.082

305,959

Sells

Buys

Sells

$\frac{(3)}{\begin{array}{c}1.909^{* * *} \\ (0.576)\end{array}}$

(4)

$1.513^{* *}$

(0.730)

1.681
1.
1

(4)

(0.472)

$1.546^{* * *}$

(0.422)

$1.424^{* *} \quad 1.196^{* *}$

(0.578)

(0.524)

Y
Y

\section{Y}

$\mathrm{N}$

319,070

305,959

0.076

0.288

319,070

0.431

The dependent variable in column 1 is the quarterly change in 'Securities holdings/TA' ( $\Delta$ Sec/TA) for each bank $b$ during quarter $t$ in the period 2007:Q3 to 2009:Q4. The dependent variable for the 'Buys' is the logarithm of the amount bought (in nominal value) by bank $b$ of security $i$ during quarter $t$, and zero otherwise. For the 'Sells', the dependent variable is the logarithm of the amount sold (in nominal value) by bank $b$ of security $i$ during quarter $t$, and zero otherwise. 'Trading bank' is a binary variable that equals the value of one if bank $b$ has membership to the largest fixed income platform in Germany (Eurex Exchange), and zero otherwise, which proxies for banks with higher trading expertise. 'Landesbank' is a binary variable that equals the value of one if bank $b$ is a Landesbank, and zero otherwise. All regressions are estimated using ordinary least squares. Lagged, time-varying bank controls (Size, Capital/TA, Interbank borrowing/TA, Deposits/TA) and fixed effects are either included ('Y'), not included (' $N$ '), or spanned by another set of fixed effects ('-'). The definition of the main independent variables can be found in Table A10. A constant is included, but its coefficient is left unreported. Robust standard errors clustered at bank level following Arellano (1987) are reported in parentheses. ***: Significant at 1 percent level; **: Significant at 5 percent level; *: Significant at 10 percent level. 
TABle 2 PANel B:

BUYING BEHAVIOR DURING THE CRISIS ACROSS SECURITIES

Dependent variable: Buys

\begin{tabular}{|c|c|c|c|c|c|}
\hline & All & Aaa-rated & Below Aaa-rated & Up to 1 Year & Above 1 Year \\
\hline & $(1)$ & $(2)$ & $(3)$ & $(4)$ & $(5)$ \\
\hline Trading bank bo $_{b} \% \Delta$ price $_{i, t-1}$ & $\begin{array}{c}-0.212^{* *} \\
(0.086)\end{array}$ & $\begin{array}{l}-0.062 \\
(0.077)\end{array}$ & $\begin{array}{c}-0.206^{* *} \\
(0.102)\end{array}$ & $\begin{array}{l}-0.128 \\
(0.485)\end{array}$ & $\begin{array}{c}-0.152^{* * *} \\
(0.058)\end{array}$ \\
\hline Landesbank $_{b} * \% \Delta$ price $_{i, t-1}$ & $\begin{array}{c}-0.334^{* * *} \\
(0.098)\end{array}$ & $\begin{array}{l}-0.040 \\
(0.088)\end{array}$ & $\begin{array}{c}-0.377^{* * *} \\
(0.100)\end{array}$ & $\begin{array}{c}0.611 \\
(0.490)\end{array}$ & $\begin{array}{c}-0.240^{* * *} \\
(0.067)\end{array}$ \\
\hline Bank controls & $\mathrm{Y}$ & $\mathrm{Y}$ & $\mathrm{Y}$ & $\mathrm{Y}$ & $\mathrm{Y}$ \\
\hline Security*Time fixed effects & $\mathrm{Y}$ & $\mathrm{Y}$ & $\mathrm{Y}$ & $\mathrm{Y}$ & $\mathrm{Y}$ \\
\hline Bank fixed effects & $\mathrm{Y}$ & $\mathrm{Y}$ & $\mathrm{Y}$ & $\mathrm{Y}$ & $\mathrm{Y}$ \\
\hline Observations & 51,512 & 16,455 & 35,057 & 8,955 & 42,557 \\
\hline R-squared & 0.616 & 0.615 & 0.629 & 0.633 & 0.621 \\
\hline
\end{tabular}

The estimations report the buying behavior of banks across different securities conditional on buying. The dependent variable is the logarithm of the amount bought (in nominal value) by bank $b$ of security $i$ during quarter $t$. The splits are based on ratings and remaining residual maturity of the securities. 'Trading bank' is a binary variable that equals the value of one if bank $b$ has membership to the largest fixed income platform in Germany (Eurex Exchange), and zero otherwise, which proxies for banks with higher trading expertise. 'Landesbank' is a binary variable that equals the value of one if bank $b$ is a Landesbank, and zero otherwise. The percentage price change of security $i$, ' $\% \Delta$ price $_{i, t-1}$ ', is demeaned by the sample mean and standardized using the standard deviation of the respective subset of securities in the crisis sample. All regressions are estimated using ordinary least squares. Lagged, time-varying bank controls (Size, Capital/TA, Interbank borrowing/TA, Deposits/TA) and fixed effects are either included ('Y'), not included ('N'), or spanned by another set of fixed effects ('-'). The definition of the main independent variables can be found in Table A10. A constant is included, but its coefficient is left unreported. Robust standard errors clustered at bank level following Arellano (1987) are reported in parentheses. ***: Significant at 1 percent level; **: Significant at 5 percent level; *: Significant at 10 percent level. 
TABle 2 PANel C:

SELLING BEHAVIOR DURING THE CRISIS ACROSS SECURITIES

Dependent variable: Sells

\begin{tabular}{|c|c|c|c|c|c|}
\hline & All & Aaa-rated & Below Aaa-rated & Up to 1 Year & Above 1 Year \\
\hline & $(1)$ & $(2)$ & $(3)$ & $(4)$ & $(5)$ \\
\hline Trading bank bo $_{b} \% \Delta$ price $_{i, t-1}$ & $\begin{array}{c}0.055 \\
(0.061)\end{array}$ & $\begin{array}{c}0.040 \\
(0.114)\end{array}$ & $\begin{array}{c}0.066 \\
(0.069)\end{array}$ & $\begin{array}{c}0.119 \\
(0.116)\end{array}$ & $\begin{array}{c}0.029 \\
(0.044)\end{array}$ \\
\hline Landesbank $_{b} * \% \Delta$ price $_{i, t-1}$ & $\begin{array}{c}0.070 \\
(0.058)\end{array}$ & $\begin{array}{c}0.063 \\
(0.110)\end{array}$ & $\begin{array}{c}0.066 \\
(0.057)\end{array}$ & $\begin{array}{c}0.310^{* *} \\
(0.158)\end{array}$ & $\begin{array}{c}0.033 \\
(0.043)\end{array}$ \\
\hline Bank controls & $\mathrm{Y}$ & $\mathrm{Y}$ & $\mathrm{Y}$ & $\mathrm{Y}$ & $\mathrm{Y}$ \\
\hline Security*Time fixed effects & $\mathrm{Y}$ & $\mathrm{Y}$ & $\mathrm{Y}$ & $\mathrm{Y}$ & $\mathrm{Y}$ \\
\hline Bank fixed effects & $\mathrm{Y}$ & $\mathrm{Y}$ & $\mathrm{Y}$ & $\mathrm{Y}$ & $\mathrm{Y}$ \\
\hline Observations & 65,972 & 19,549 & 46,423 & 20,069 & 45,903 \\
\hline R-squared & 0.584 & 0.604 & 0.588 & 0.564 & 0.601 \\
\hline
\end{tabular}

The estimations report the selling behavior of banks across different securities conditional on selling. The dependent variable is the logarithm of the amount sold (in nominal value) by bank $b$ of security $i$ during quarter $t$. The splits are based on ratings and remaining residual maturity of the securities. 'Trading bank' is a binary variable that equals the value of one if bank $b$ has membership to the largest fixed income platform in Germany (Eurex Exchange), and zero otherwise, which proxies for banks with higher trading expertise. The percentage price change of security $i$, '\% $\%$ price $_{i, t-1}$ ', is demeaned by the sample mean and standardized using the standard deviation of the respective subset of securities in the crisis sample. 'Landesbank' is a binary variable that equals the value of one if bank $b$ is a Landesbank, and zero otherwise. All regressions are estimated using ordinary least squares. Lagged, time-varying bank controls (Size, Capital/TA, Interbank borrowing/TA, Deposits/TA) and fixed effects are either included ('Y'), not included ('N'), or spanned by another set of fixed effects ('-)'. The definition of the main independent variables can be found in Table A10. A constant is included, but its coefficient is left unreported. Robust standard errors clustered at bank level following Arellano (1987) are reported ***, Significant at 1 percent level; **, Significant at 5 
TABLE 3:

TRADING BEHAVIOR OF SECURITIES WITH THE LARGEST PRICE DROP

Dependent variable:

Trading bank $b$

Landesbank $_{b}$

Bank controls

Security*Time fixed effects

Time fixed effects

Observations

R-squared

\begin{tabular}{c}
$\Delta \mathrm{Sec} / \mathrm{TA}$ \\
\hline$(1)$ \\
\hline $0.393^{* *}$ \\
$(0.161)$ \\
$0.232^{*}$ \\
$(0.118)$ \\
\hline
\end{tabular}

$\mathrm{Y}$

$\mathrm{Y}$

4,254

This table replicates Panel A of Table 2 for those securities that had the largest price drop (25th percentile) in the previous quarter. The dependent variable in column 1 is the quarterly change in 'Securities holdings/TA' ( $\Delta$ Sec/TA) for each bank $b$ during quarter $t$ in the period 2007:Q3 to 2009:Q4. The dependent variable for the 'Buys' is the logarithm of the amount bought (in nominal value) by bank $b$ of security $i$ during quarter $t$, and zero otherwise. For the 'Sells', the dependent variable is the logarithm of the amount sold (in nominal value) by bank $b$ of security $i$ during quarter $t$, and zero otherwise. 'Trading bank' is a binary variable that equals the value of one if bank $b$ has membership to the largest fixed income platform in Germany (Eurex Exchange), and zero otherwise, which proxies for banks with higher trading expertise. 'Landesbank' is a binary variable that equals the value of one if bank $b$ is a Landesbank, and zero otherwise. All regressions are estimated using ordinary least squares. Lagged, time-varying bank controls (Size, Capital/TA, Interbank borrowing/TA, Deposits/TA) and fixed effects are either included (' $\mathrm{Y}$ '), not included ('N'), or spanned by another set of fixed effects ('-'). The definition of the main independent variables can be found in Table A10. A constant is included, but its coefficient is left unreported. Robust standard errors clustered at bank level following Arellano (1987) are reported in parentheses. ***: Significant at 1 percent level; **: Significant at 5 percent level; *: Significant at 10 percent level. 
TABLE 4:

BUYING BEHAVIOR OF SECURITIES WITH THE LARGEST PRICE DROP:

\section{THE IMPACT OF TRADING GAINS AND SUBPRIME EXPOSURE}

\begin{tabular}{|c|c|c|c|c|c|c|c|c|c|}
\hline & & & & Deper & ent variabl & : Buys & & & \\
\hline & $(1)$ & $(2)$ & $(3)$ & $(4)$ & $(5)$ & (6) & $(7)$ & $(8)$ & $(9)$ \\
\hline Trading bank $_{b}$ & $\begin{array}{c}1.268^{* * *} \\
(0.346)\end{array}$ & $\begin{array}{c}1.416^{* * *} \\
(0.396)\end{array}$ & $\begin{array}{c}1.379^{* * *} \\
(0.419)\end{array}$ & $\begin{array}{c}1.190^{* * *} \\
(0.339)\end{array}$ & $\begin{array}{c}1.510^{* * *} \\
(0.388)\end{array}$ & $\begin{array}{c}1.189^{* * *} \\
(0.383)\end{array}$ & $\begin{array}{c}1.375^{* * *} \\
(0.423)\end{array}$ & $\begin{array}{c}1.369^{* * *} \\
(0.424)\end{array}$ & $\begin{array}{c}1.258^{* * *} \\
(0.353)\end{array}$ \\
\hline Landesbank $_{b}$ & $\begin{array}{l}1.181^{* *} \\
(0.481)\end{array}$ & $\begin{array}{c}1.194^{* *} \\
(0.502)\end{array}$ & $\begin{array}{l}1.264^{* *} \\
(0.510)\end{array}$ & $\begin{array}{l}1.112^{* *} \\
(0.454)\end{array}$ & $\begin{array}{l}1.100^{* *} \\
(0.478)\end{array}$ & $\begin{array}{l}0.965^{*} \\
(0.575)\end{array}$ & $\begin{array}{c}1.261^{* *} \\
(0.509)\end{array}$ & $\begin{array}{l}1.259^{* *} \\
(0.509)\end{array}$ & $\begin{array}{l}1.178^{* *} \\
(0.482)\end{array}$ \\
\hline Gains on pre-crisis holdings $s_{b, t-1}$ & $\begin{array}{c}1.189^{* * *} \\
(0.295)\end{array}$ & & & & & & & & $\begin{array}{c}1.193^{* * *} \\
(0.296)\end{array}$ \\
\hline Gains on pre-crisis subprime holdings $\mathrm{s}_{b, t-1}$ & & $\begin{array}{c}4.819^{* * *} \\
(1.368)\end{array}$ & & & & & & & \\
\hline Gains on securities $b, i, t-1$ & & & $\begin{array}{c}5.522^{* *} \\
(2.181)\end{array}$ & & & & & & \\
\hline Gains on holdings $s_{b, t-1}$ & & & & $\begin{array}{c}1.482^{* * *} \\
(0.233)\end{array}$ & & & & & \\
\hline Subprime exposure $/ \mathrm{TA}_{b}$ & & & & & $\begin{array}{c}-0.070^{* *} \\
(0.028)\end{array}$ & & & & \\
\hline Off-balance sheet exposure $/ \mathrm{TA}_{b}$ & & & & & & $\begin{array}{l}0.050 \\
(0.039)\end{array}$ & & & \\
\hline Profits from derivatives trading $/ \mathrm{TA}_{b, t-1}$ & & & & & & & $\begin{array}{l}-0.004 \\
(0.180)\end{array}$ & & \\
\hline Profits from overall trading $/ \mathrm{TA}_{b, t-1}$ & & & & & & & & $\begin{array}{c}0.056 \\
(0.172)\end{array}$ & $\begin{array}{c}0.093 \\
(0.155)\end{array}$ \\
\hline Bank controls & $\mathrm{Y}$ & $\mathrm{Y}$ & $\mathrm{Y}$ & Y & $\mathrm{Y}$ & $\mathrm{Y}$ & $\mathrm{Y}$ & $\mathrm{Y}$ & $\mathrm{Y}$ \\
\hline Security*Time fixed effects & $\mathrm{Y}$ & $\mathrm{Y}$ & $\mathrm{Y}$ & Y & $\mathrm{Y}$ & $\mathrm{Y}$ & $\mathrm{Y}$ & $\mathrm{Y}$ & $\mathrm{Y}$ \\
\hline Observations & 79,530 & 79,530 & 79,530 & 79,530 & 79,530 & 79,530 & 79,530 & 79,530 & 79,530 \\
\hline R-squared & 0.300 & 0.298 & 0.297 & 0.306 & 0.299 & 0.298 & 0.297 & 0.297 & 0.300 \\
\hline
\end{tabular}

The sample is restricted to those securities that had the largest price drop (25th percentile) in the previous quarter. The dependent variable is the logarithm of the amount bought (in nominal value) by bank $b$ of security $i$ during quarter $t$, and zero otherwise. 'Trading bank' is a binary variable that equals one when bank $b$ has membership to the largest fixed income platform in Germany (Eurex Exchange), and zero otherwise, which proxies for banks with higher trading expertise. 'Landesbank' is a binary variable that equals the value of one if bank $b$ is a Landesbank, and zero otherwise. All regressions are estimated using ordinary least squares. Lagged, time-varying bank controls (Size, Capital/TA, Interbank borrowing/TA, Deposits/TA) and fixed effects are either included (' $Y$ '), not included ('N'), or spanned by another set of fixed effects ('-'). The definition of the main independent variables can be found in Table A10. A constant is included, but its coefficient is left unreported. Robust standard errors clustered at bank level following Arellano (1987) are reported in parentheses. ***: Significant at 1 percent level; **: Significant at 5 percent level; *: Significant at 10 percent level. 
TABLE 5:

BUYING BEHAVIOR OF SECURITIES WITH THE LARGEST PRICE DROP:

THE IMPACT OF CAPITAL AND TRADING GAINS

\begin{tabular}{|c|c|c|c|c|c|}
\hline & \multicolumn{5}{|c|}{ Dependent variable: Buys } \\
\hline & (1) & $(2)$ & $(3)$ & $(4)$ & $(5)$ \\
\hline Trading bank $_{b}$ & $\begin{array}{c}1.649^{* * *} \\
(0.425)\end{array}$ & $\begin{array}{c}1.715^{* * *} \\
(0.393)\end{array}$ & $\begin{array}{c}1.624^{* * *} \\
(0.576)\end{array}$ & $\begin{array}{c}1.739^{* * * *} \\
(0.380)\end{array}$ & $\begin{array}{c}1.826 * * * \\
(0.341)\end{array}$ \\
\hline Landesbank $_{b}$ & $\begin{array}{c}1.281^{* * *} \\
(0.482)\end{array}$ & $\begin{array}{c}0.939 * * \\
(0.450)\end{array}$ & $\begin{array}{c}0.722 \\
(0.458)\end{array}$ & $\begin{array}{c}1.748 * * \\
(0.838)\end{array}$ & $\begin{array}{c}1.079 \\
(1.019)\end{array}$ \\
\hline Capital $/ \mathrm{TA}_{b, t-1}$ & $\begin{array}{c}0.113 \\
(0.069)\end{array}$ & $\begin{array}{l}-0.002 \\
(0.049)\end{array}$ & $\begin{array}{l}-0.044 \\
(0.057)\end{array}$ & $\begin{array}{c}0.112 \\
(0.069)\end{array}$ & $\begin{array}{c}0.019 \\
(0.029)\end{array}$ \\
\hline Gains on pre-crisis holdings $\mathrm{s}_{b, t-1}$ & $\begin{array}{c}0.844^{* * *} \\
(0.293)\end{array}$ & $\begin{array}{c}0.732^{* * *} \\
(0.265)\end{array}$ & & $\begin{array}{c}0.752^{* * *} \\
(0.236)\end{array}$ & $\begin{array}{c}0.655^{* * *} \\
(0.179)\end{array}$ \\
\hline Trading $\operatorname{bank}_{b} *$ Gains on pre-crisis holdings $s_{b, t-1}$ & $\begin{array}{l}1.462^{*} \\
(0.766)\end{array}$ & $\begin{array}{l}0.997^{*} \\
(0.601)\end{array}$ & & $\begin{array}{c}1.606^{* *} \\
(0.700)\end{array}$ & $\begin{array}{c}1.123^{* *} \\
(0.498)\end{array}$ \\
\hline Trading $\operatorname{bank}_{b}{ }^{*}$ Capital $/ \mathrm{TA}_{b, t-1}$ & & $\begin{array}{c}0.338^{* * *} \\
(0.127)\end{array}$ & $\begin{array}{c}0.377^{* * *} \\
(0.140)\end{array}$ & & $\begin{array}{c}0.323^{* * *} \\
(0.123)\end{array}$ \\
\hline Tier1 buffer $_{b, t-1}$ & & & $\begin{array}{c}0.013 \\
(0.020)\end{array}$ & & \\
\hline Trading bank $_{b} *$ Tier1 buffer $_{b, t-1}$ & & & $\begin{array}{l}-0.017 \\
(0.063)\end{array}$ & & \\
\hline Landesbank $_{b} *$ Gains on pre-crisis holdings $s_{b, t-1}$ & & & & $\begin{array}{c}2.120 \\
(3.011)\end{array}$ & $\begin{array}{c}3.032 \\
(3.040)\end{array}$ \\
\hline Landesbank $_{b}{ }^{*}$ Capital/TA TA $_{b, t-1}$ & & & & & $\begin{array}{c}-0.293 \\
(0.380)\end{array}$ \\
\hline Bank controls & $\mathrm{Y}$ & $\mathrm{Y}$ & $\mathrm{Y}$ & $\mathrm{Y}$ & $\mathrm{Y}$ \\
\hline Security*Time fixed effects & $\mathrm{Y}$ & $\mathrm{Y}$ & $\mathrm{Y}$ & $\mathrm{Y}$ & $\mathrm{Y}$ \\
\hline Observations & 79,530 & 79,530 & 76,942 & 79,530 & 79,530 \\
\hline R-squared & 0.300 & 0.303 & 0.306 & 0.301 & 0.304 \\
\hline
\end{tabular}

The sample is restricted to those securities that had the largest price drop (25th percentile) in the previous quarter. The dependent variable is the logarithm of the amount bought (in nominal value) by bank $b$ of security $i$ during quarter $t$, and zero otherwise. 'Trading bank' is a binary variable that equals one when bank $b$ has membership to the largest fixed income platform in Germany (Eurex Exchange), and zero otherwise, which proxies for banks with higher trading expertise. 'Landesbank' is a binary variable that equals the value of one if bank $b$ is a Landesbank, and zero otherwise. 'Capital/ $\mathrm{TA}_{b, t-1}$ ' measures the book value of equity as a fraction of total assets (in \%) for bank $b$ in quarter $t-1$. All regressions are estimated using ordinary least squares. Lagged, time-varying bank controls (Size, Interbank borrowing/TA, Deposits/TA) and fixed effects are either included ('Y'), not included ('N'), or spanned by another set of fixed effects ('-'). The definition of the main independent variables can be found in Table A10. A constant is included, but its coefficient is left unreported. Robust standard errors clustered at bank level following Arellano (1987) are reported in parentheses. ***: Significant at 1 percent level; **: Significant at 5 percent level; *: Significant at 10 percent level. 
TABLE 6:

BUYING BEHAVIOR OF SECURITIES WITH THE LARGEST PRICE DROP: THE IMPACT OF GOVERNMENT SUBSIDIES

\begin{tabular}{|c|c|c|c|c|c|}
\hline & \multicolumn{5}{|c|}{ Dependent variable: Buys } \\
\hline & $(1)$ & $(2)$ & $(3)$ & $(4)$ & $(5)$ \\
\hline Trading bank $_{b}$ & $\begin{array}{c}2.177^{* * *} \\
(0.349)\end{array}$ & $\begin{array}{c}2.282^{* * *} \\
(0.363)\end{array}$ & $\begin{array}{c}1.849^{* * *} \\
(0.329)\end{array}$ & $\begin{array}{c}1.851^{* * *} \\
(0.329)\end{array}$ & $\begin{array}{c}1.997^{* * *} \\
(0.322)\end{array}$ \\
\hline Landesbank $_{b}$ & $\begin{array}{l}1.653^{*} \\
(0.894)\end{array}$ & $\begin{array}{c}1.801^{* *} \\
(0.889)\end{array}$ & $\begin{array}{c}0.877 \\
(1.014)\end{array}$ & $\begin{array}{c}1.032 \\
(0.920)\end{array}$ & $\begin{array}{l}1.271 \\
(0.804)\end{array}$ \\
\hline Capital/TA $\mathrm{TA}_{b, t-1}$ & $\begin{array}{l}-0.003 \\
(0.038)\end{array}$ & $\begin{array}{l}-0.003 \\
(0.039)\end{array}$ & $\begin{array}{c}0.019 \\
(0.029)\end{array}$ & $\begin{array}{l}0.020 \\
(0.029)\end{array}$ & $\begin{array}{c}0.019 \\
(0.030)\end{array}$ \\
\hline Gains on pre-crisis holdings $s_{b, t-1}$ & $\begin{array}{c}0.767^{* * *} \\
(0.191)\end{array}$ & $\begin{array}{c}0.720^{* * *} \\
(0.185)\end{array}$ & $\begin{array}{c}0.732^{* * *} \\
(0.183)\end{array}$ & $\begin{array}{c}0.749^{* * *} \\
(0.185)\end{array}$ & $\begin{array}{c}0.804^{* * *} \\
(0.177)\end{array}$ \\
\hline Trading bank $_{b}{ }^{*}$ Gains on pre-crisis holdings $\mathrm{s}_{b, t-1}$ & $\begin{array}{l}0.892^{*} \\
(0.476)\end{array}$ & $\begin{array}{l}1.053^{* *} \\
(0.503)\end{array}$ & $\begin{array}{c}1.262^{* * *} \\
(0.401)\end{array}$ & $\begin{array}{c}1.248^{* * *} \\
(0.398)\end{array}$ & $\begin{array}{c}0.645 \\
(0.412)\end{array}$ \\
\hline Trading $\operatorname{bank}_{b} *$ Capital $/ \mathrm{TA}_{b, t-1}$ & $\begin{array}{c}0.489^{* * *} \\
(0.107)\end{array}$ & $\begin{array}{c}0.523^{* * *} \\
(0.118)\end{array}$ & $\begin{array}{c}0.400^{* * *} \\
(0.100)\end{array}$ & $\begin{array}{c}0.401^{* * *} \\
(0.100)\end{array}$ & $\begin{array}{c}0.493^{* * *} \\
(0.097)\end{array}$ \\
\hline Landesbank $_{b}{ }^{*}$ Gains on pre-crisis holdings $s_{b, t-1}$ & $\begin{array}{l}4.386^{*} \\
(2.413)\end{array}$ & $\begin{array}{l}4.864^{* *} \\
(2.401)\end{array}$ & $\begin{array}{c}2.214 \\
(3.022)\end{array}$ & $\begin{array}{c}2.256 \\
(2.969)\end{array}$ & $\begin{array}{c}2.659 \\
(2.555)\end{array}$ \\
\hline Landesbank ${ }_{b}{ }^{*}$ Capital $/ \mathrm{TA}_{b, t-1}$ & $\begin{array}{l}-0.102 \\
(0.290)\end{array}$ & $\begin{array}{l}-0.085 \\
(0.290)\end{array}$ & $\begin{array}{l}-0.290 \\
(0.338)\end{array}$ & $\begin{array}{l}-0.299 \\
(0.336)\end{array}$ & $\begin{array}{l}-0.256 \\
(0.286)\end{array}$ \\
\hline Public support $_{b}$ & $\begin{array}{c}1.260^{* *} \\
(0.579)\end{array}$ & & & & $\begin{array}{c}1.181^{* * *} \\
(0.422)\end{array}$ \\
\hline After public support ${ }_{b, t}$ & & $\begin{array}{c}0.957^{*} \\
(0.546)\end{array}$ & & & \\
\hline Before public support ${ }_{b, t}$ & & $\begin{array}{l}1.693^{* *} \\
(0.669)\end{array}$ & & & \\
\hline Central bank borrowing/ $\mathrm{TA}_{b, t-1}$ & & & $\begin{array}{l}-0.007 \\
(0.006)\end{array}$ & $\begin{array}{l}-0.004 \\
(0.006)\end{array}$ & $\begin{array}{l}-0.003 \\
(0.006)\end{array}$ \\
\hline $\begin{array}{l}\text { Central bank borrowing } / \mathrm{TA}_{b, t-1} * \\
\text { Gains on pre-crisis holdings } \\
b, t-1\end{array}$ & & & $\begin{array}{l}0.026^{*} \\
(0.015)\end{array}$ & $\begin{array}{l}0.027^{*} \\
(0.015)\end{array}$ & $\begin{array}{c}0.028^{* *} \\
(0.014)\end{array}$ \\
\hline Trading bank ${ }_{b} *$ Central bank borrowing $/ \mathrm{TA}_{b, t-1}$ & & & $\begin{array}{c}0.068^{* * *} \\
(0.013)\end{array}$ & $\begin{array}{c}0.065^{* * *} \\
(0.013)\end{array}$ & $\begin{array}{c}0.070 * * * \\
(0.015)\end{array}$ \\
\hline Landesbank $_{b} *$ Central bank borrowing $/ \mathrm{TA}_{b, t-1}$ & & & & $\begin{array}{l}-0.024 \\
(0.028)\end{array}$ & $\begin{array}{l}-0.033 \\
(0.056)\end{array}$ \\
\hline Bank controls & $\mathrm{Y}$ & $\mathrm{Y}$ & $\mathrm{Y}$ & $\mathrm{Y}$ & $\mathrm{Y}$ \\
\hline Security*Time fixed effects & $\mathrm{Y}$ & $\mathrm{Y}$ & $\mathrm{Y}$ & $\mathrm{Y}$ & $\mathrm{Y}$ \\
\hline Observations & 72,709 & 72,709 & 72,709 & 72,709 & 72,709 \\
\hline R-squared & 0.318 & 0.318 & 0.319 & 0.319 & 0.320 \\
\hline
\end{tabular}

The sample is restricted to those securities that had the largest price drop (25th percentile) in the previous quarter. The dependent variable is the logarithm of the amount bought (in nominal value) by bank $b$ of security $i$ during quarter $t$, and zero otherwise. 'Trading bank' is a binary variable that equals one when bank $b$ has membership to the largest fixed income platform in Germany (Eurex Exchange), and zero otherwise, which proxies for banks with higher trading expertise. 'Landesbank' is a binary variable that equals the value of one if bank $b$ is a Landesbank, and zero otherwise. 'Capital/ $\mathrm{TA}_{b, t-1}$ ' measures the book value of equity as a fraction of total assets (in \%) for bank $b$ in quarter $t-1$. All regressions are estimated using ordinary least squares. Lagged, time-varying bank controls (Size, Interbank borrowing/TA, Deposits (TA) and fixed effects are either included (' $\mathrm{Y}$ '), not included (' $\mathrm{N}$ '), or spanned by another set of fixed effects ('-'). The definition of the main independent variables can be found in Table A10. A constant is included, but its coefficient is left unreported. Robust standard errors clustered at bank level following Arellano (1987) are reported in parentheses. ***: Significant at 1 percent level; **: Significant at 5 percent level; *: Significant at 10 percent level. 
TABLE 7:

BUYING BEHAVIOR OF SECURITIES WITH THE LARGEST PRICE DROP BEFORE THE CRISIS:

THE IMPACT OF GOVERNMENT SUBSIDIES

\begin{tabular}{|c|c|c|c|}
\hline & \multicolumn{3}{|c|}{ Dependent variable: Buys } \\
\hline & (1) & $(2)$ & $(3)$ \\
\hline Trading bank $_{b}$ & $\begin{array}{c}2.288^{* * *} \\
(0.690)\end{array}$ & $\begin{array}{c}2.993^{* * *} \\
(0.654)\end{array}$ & $\begin{array}{c}3.243^{* * *} \\
(0.506)\end{array}$ \\
\hline Landesbank $_{b}$ & $\begin{array}{l}1.521^{* *} \\
(0.658)\end{array}$ & $\begin{array}{c}0.807 \\
(1.049)\end{array}$ & $\begin{array}{c}2.298^{* * *} \\
(0.821)\end{array}$ \\
\hline Public support $_{b}$ & $\begin{array}{c}1.953^{* * *} \\
(0.734)\end{array}$ & $\begin{array}{c}1.681^{* *} \\
(0.855)\end{array}$ & $\begin{array}{c}2.492^{* * *} \\
(0.684)\end{array}$ \\
\hline Capital $/ \mathrm{TA}_{b, t-1}$ & $\begin{array}{c}0.082 \\
(0.074)\end{array}$ & $\begin{array}{c}0.019 \\
(0.051)\end{array}$ & $\begin{array}{c}0.074 \\
(0.050)\end{array}$ \\
\hline Trading $\operatorname{bank}_{b}{ }^{*}$ Capital $/ \mathrm{TA}_{b, t-1}$ & & $\begin{array}{c}0.523^{* *} \\
(0.211)\end{array}$ & $\begin{array}{c}0.387^{* *} \\
(0.170)\end{array}$ \\
\hline Landesbank $_{b}{ }^{*}$ Capital $/ \mathrm{TA}_{b, t-1}$ & & $\begin{array}{l}-0.269 \\
(0.450)\end{array}$ & $\begin{array}{l}-0.278 \\
(0.255)\end{array}$ \\
\hline Gains on holdings $s_{b, t-1}$ & & & $\begin{array}{c}2.825^{* * *} \\
(0.405)\end{array}$ \\
\hline Trading $\operatorname{bank}_{b}{ }^{*}$ Gains on holdings $s_{b, t-1}$ & & & $\begin{array}{c}3.205^{* * *} \\
(1.142)\end{array}$ \\
\hline $\operatorname{Landesbank}_{b}{ }^{*}$ Gains on holdings $\mathrm{S}_{b, t-1}$ & & & $\begin{array}{c}8.685^{* * *} * \\
(2.485) \\
\end{array}$ \\
\hline Bank controls & $\mathrm{Y}$ & $\mathrm{Y}$ & $\mathrm{Y}$ \\
\hline Security*Time fixed effects & $\mathrm{Y}$ & $\mathrm{Y}$ & $\mathrm{Y}$ \\
\hline Observations & 32,864 & 32,864 & 32,864 \\
\hline R-squared & 0.256 & 0.261 & 0.285 \\
\hline
\end{tabular}

This table replicates column 1 of Table 6 for the period before the crisis (2006:Q1 - 2007:Q2). The sample is restricted to those securities that had the largest price drop (25th percentile) in the previous quarter. The dependent variable is the logarithm of the amount bought (in nominal value) by bank $b$ of security $i$ during quarter $t$, and zero otherwise. 'Trading bank' is a binary variable that equals one when bank $b$ has membership to the largest fixed income platform in Germany (Eurex Exchange), and zero otherwise, which proxies for banks with higher trading expertise. 'Landesbank' is a binary variable that equals the value of one if bank $b$ is a Landesbank, and zero otherwise. 'Capital/TA $\mathrm{TA}_{b, t}$ ' measures the book value of equity as a fraction of total assets (in \%) for bank $b$ in quarter $t-1$. All regressions are estimated using ordinary least squares. Lagged, time-varying bank controls (Size, Interbank borrowing/TA, Deposits/TA) and fixed effects are either included ('Y'), not included ('N'), or spanned by another set of fixed effects ('-'). The definition of the main independent variables can be found in Table A10. A constant is included, but its coefficient is left unreported. Robust standard errors clustered at bank level following Arellano (1987) are reported in parentheses. ***: Significant at 1 percent level; **: Significant at 5 percent level; *: Significant at 10 percent level. 
TABLE 8:

SELliNg BEHAVIOR OF SECURITIES WITH THE LARGEST PRICE DROP: THE IMPACT OF TRADING GAINS, CAPITAL, AND GOVERNMENT SUBSIDIES

\begin{tabular}{|c|c|c|c|c|c|c|}
\hline & \multicolumn{6}{|c|}{ Dependent variable: Sells } \\
\hline & (1) & $(2)$ & $(3)$ & $(4)$ & $(5)$ & (6) \\
\hline Trading bank $_{b}$ & $\begin{array}{c}1.697^{* * *} \\
(0.419)\end{array}$ & $\begin{array}{c}1.715^{* * *} \\
(0.420)\end{array}$ & $\begin{array}{c}1.809 * * * \\
(0.427)\end{array}$ & $\begin{array}{c}1.707^{* * *} \\
(0.420)\end{array}$ & $\begin{array}{c}1.555^{* * *} \\
(0.421)\end{array}$ & $\begin{array}{c}1.765^{* * *} \\
(0.452)\end{array}$ \\
\hline Landesbank $_{b}$ & $\begin{array}{l}1.243^{* *} \\
(0.541)\end{array}$ & $\begin{array}{l}1.230 \\
(0.861)\end{array}$ & $\begin{array}{l}1.485^{*} \\
(0.815)\end{array}$ & $\begin{array}{l}1.215^{* *} \\
(0.529)\end{array}$ & $\begin{array}{l}0.969^{*} \\
(0.532)\end{array}$ & $\begin{array}{c}1.274 \\
(0.915)\end{array}$ \\
\hline Trading bank $_{b} *$ Capital $/ \mathrm{TA}_{b, t-1}$ & $\begin{array}{c}0.299^{* *} \\
(0.123)\end{array}$ & $\begin{array}{c}0.301^{* *} \\
(0.129)\end{array}$ & $\begin{array}{c}0.329 * * * \\
(0.126)\end{array}$ & $\begin{array}{c}0.295^{* *} \\
(0.124)\end{array}$ & $\begin{array}{l}0.241^{* *} \\
(0.119)\end{array}$ & $\begin{array}{l}0.224^{*} \\
(0.115)\end{array}$ \\
\hline Capital $/ \mathrm{TA}_{b, t-1}$ & $\begin{array}{l}-0.043 \\
(0.047)\end{array}$ & $\begin{array}{l}-0.041 \\
(0.046)\end{array}$ & $\begin{array}{l}-0.042 \\
(0.047)\end{array}$ & $\begin{array}{l}-0.041 \\
(0.050)\end{array}$ & $\begin{array}{l}-0.010 \\
(0.049)\end{array}$ & $\begin{array}{l}-0.011 \\
(0.048)\end{array}$ \\
\hline Gains on pre-crisis holdings $\mathrm{s}_{b, t-1}$ & $\begin{array}{c}0.803^{* * *} \\
(0.196)\end{array}$ & $\begin{array}{c}0.793^{* * *} \\
(0.189)\end{array}$ & $\begin{array}{c}0.726^{* * *} \\
(0.177)\end{array}$ & $\begin{array}{c}0.817^{* * *} \\
(0.203)\end{array}$ & $\begin{array}{c}1.080^{* * *} \\
(0.214)\end{array}$ & $\begin{array}{c}1.017^{* * *} \\
(0.211)\end{array}$ \\
\hline $\begin{array}{l}\text { Trading bank }{ }^{*} \\
\text { Gains on pre-crisis holdings } b, t-1\end{array}$ & $\begin{array}{c}0.085 \\
(0.846)\end{array}$ & $\begin{array}{l}-0.085 \\
(0.771)\end{array}$ & $\begin{array}{c}0.168 \\
(0.793)\end{array}$ & $\begin{array}{c}0.031 \\
(0.878)\end{array}$ & $\begin{array}{c}0.032 \\
(0.791)\end{array}$ & $\begin{array}{c}0.916 \\
(1.142)\end{array}$ \\
\hline $\begin{array}{l}\text { Landesbank }{ }_{b}{ }^{*} \\
\text { Gains on pre-crisis holdings } s_{b, t-1}\end{array}$ & $\begin{array}{l}1.656 \\
(2.073)\end{array}$ & $\begin{array}{l}1.524 \\
(1.940)\end{array}$ & $\begin{array}{c}2.181 \\
(1.911)\end{array}$ & $\begin{array}{c}1.614 \\
(2.158)\end{array}$ & $\begin{array}{c}0.933 \\
(2.125)\end{array}$ & $\begin{array}{c}1.734 \\
(2.236)\end{array}$ \\
\hline Landesbank $_{b}{ }^{*}$ Capital $/ \mathrm{TA}_{b, t-1}$ & $\begin{array}{c}0.079 \\
(0.191)\end{array}$ & $\begin{array}{c}0.130 \\
(0.231)\end{array}$ & $\begin{array}{c}0.174 \\
(0.218)\end{array}$ & $\begin{array}{c}0.088 \\
(0.191)\end{array}$ & $\begin{array}{c}0.055 \\
(0.188)\end{array}$ & $\begin{array}{c}0.132 \\
(0.237)\end{array}$ \\
\hline Public support ${ }_{b}$ & & $\begin{array}{c}1.559^{* * *} \\
(0.564)\end{array}$ & & & & $\begin{array}{l}1.291^{* *} \\
(0.560)\end{array}$ \\
\hline After public support ${ }_{b, t}$ & & & $\begin{array}{l}1.058^{* *} \\
(0.525)\end{array}$ & & & \\
\hline Before public support ${ }_{b, t}$ & & & $\begin{array}{c}2.103^{* * *} \\
(0.649)\end{array}$ & & & \\
\hline Central bank borrowing/ $\mathrm{TA}_{b, t-1}$ & & & & $\begin{array}{c}0.019 \\
(0.014)\end{array}$ & $\begin{array}{c}0.034^{* *} \\
(0.016)\end{array}$ & $\begin{array}{c}0.033^{* *} \\
(0.016)\end{array}$ \\
\hline $\begin{array}{l}\text { Central bank borrowing/ } / \mathrm{TA}_{b, t-1} * \\
\text { Gains on pre-crisis holdings } b, t-1\end{array}$ & & & & & $\begin{array}{c}0.058^{* * *} \\
(0.020)\end{array}$ & $\begin{array}{c}0.049 * * \\
(0.021)\end{array}$ \\
\hline $\begin{array}{l}\text { Public support }_{b}{ }^{*} \\
\text { Gains on pre-crisis holdings } b, t-1\end{array}$ & & & & & & $\begin{array}{l}-1.605 \\
(1.030)\end{array}$ \\
\hline Bank controls & $\mathrm{Y}$ & $\mathrm{Y}$ & $\mathrm{Y}$ & $\mathrm{Y}$ & $\mathrm{Y}$ & $\mathrm{Y}$ \\
\hline Security*Time fixed effects & $\mathrm{Y}$ & $\mathrm{Y}$ & $\mathrm{Y}$ & $\mathrm{Y}$ & $\mathrm{Y}$ & $\mathrm{Y}$ \\
\hline Observations & 83,015 & 83,015 & 83,015 & 83,015 & 83,015 & 83,015 \\
\hline R-squared & 0.414 & 0.414 & 0.415 & 0.414 & 0.415 & 0.415 \\
\hline
\end{tabular}

The sample is restricted to those securities that had the largest price drop (25th percentile) in the previous quarter. The dependent variable is the logarithm of the amount sold (in nominal value) by bank $b$ of security $i$ during quarter $t$, and zero otherwise. 'Trading bank' is a binary variable that equals one when bank $b$ has membership to the largest fixed income platform in Germany (Eurex Exchange), and zero otherwise, which proxies for banks with higher trading expertise. 'Landesbank' is a binary variable that equals the value of one if bank $b$ is a Landesbank, and zero otherwise. 'Capital/ $\mathrm{TA}_{b, t-1}$ ' measures the book value of equity as a fraction of total assets (in \%) for bank $b$ in quarter $t-1$. All regressions are estimated using ordinary least squares. Lagged, time-varying bank controls (Size, Interbank borrowing/TA, Deposits/TA) and fixed effects are either included (' $\mathrm{Y}$ '), not included ('N'), or spanned by another set of fixed effects ('-'). The definition of the main independent variables can be found in Table A10. A constant is included, but its coefficient is left unreported. Robust standard errors clustered at bank level following Arellano (1987) are reported in parentheses. ***: Significant at 1 percent level; **: Significant at 5 percent level; *: Significant at 10 percent level. 
TABLE 9:

LENDING BEHAVIOR DURING THE CRISIS

Trading $\operatorname{bank}_{b}$

Landesbank $_{b}$

Trading $\operatorname{bank}_{b}{ }^{*}$ Capital $/ \mathrm{TA}_{b, t-}$

Non-Trading bank $_{b} *$ Capital $/ \mathrm{TA}_{b, t-1}$

Landesbank ${ }_{b}{ }^{\text {Capital }} / \mathrm{TA}_{b, t-1}$

Gains on pre-crisis holdings $s_{b, t-1}$

Central bank borrowing/ $\mathrm{TA}_{b, t-1}$

Central bank borrowing $/ \mathrm{TA}_{b, t-1} *$

Gains on pre-crisis holdings $s_{b, t-1}$

Public support $_{b}$

Trading $\operatorname{bank}_{b} *$ Future default $j, t$

Bank controls

Borrower*Time fixed effects

Time fixed effects

Observations

R-squared

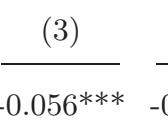

$(0.020)$

(0.020)

$-0.004$

$(0.021)$

$-0.009^{*}$

$(0.005)$

0.000

$(0.003)$

$-0.010$

$(0.008)$ $\frac{(4)}{-0.056^{* * *}}-$

$(0.020)$

$-0.005$

(0.021)

$-0.009 *$

$(0.005)$

0.000

$-0.011$

$(0.008)$

0.024

$(0.044)$

$$
\begin{gathered}
0.000 \\
(0.001)
\end{gathered}
$$

$\frac{(5)}{-0.055^{* * *}}$

$\frac{(6)}{.055^{* * *}}$

$\frac{(7)}{-0.034^{*}}$

$\frac{(8)}{-0.055^{* * *}}$

$\frac{(9)}{-0.017^{* * *}}$

(10)

$(0.020)$

$(0.019)$

$(0.020)$

$-0.017 * * *$

$0.006^{* * *}$

$\frac{(11)}{017 * * *}$

$-0.004$

$-0.005$

0.024

$-0.004$

$-0.009^{*}$

$0.021)$

$-0.009^{*}$

$(0.005) \quad(0.005)$

$-0.008$

(0.006)

(0.021)

$-0.009 *$

(0.005)

$(0.003)$

$-0.010 \quad-0.010$

$-0.002$

0.000

(0.003)

(0.008)

0.023

(0.045)

0.011

$-0.010$

$(0.012)$

(0.008)

\subsection{0
$(0.001)$}

$-0.004$

$(0.004)$

$-0.049^{* * *}$

(0.014)

\begin{tabular}{|c|c|c|}
\hline $\mathrm{Y}$ & Y & Y \\
\hline $\mathrm{N}$ & $\mathrm{Y}$ & Y \\
\hline $\mathrm{Y}$ & - & - \\
\hline 710,718 & 710,718 & 710,718 \\
\hline 0.008 & 0.441 & 0.441 \\
\hline
\end{tabular}

\begin{tabular}{c}
-0.018 \\
$(0.035)$ \\
\hline
\end{tabular}

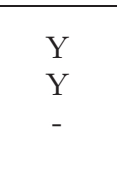

Y
Y
-

Y
Y
-

\begin{tabular}{l}
\hline \\
Y \\
-
\end{tabular}

Y
Y
-

$\mathrm{N}$
$\mathrm{N}$
$\mathrm{Y}$

$\mathrm{N}$
$\mathrm{N}$
$\mathrm{Y}$

$\mathrm{N}$
$\mathrm{N}$
$\mathrm{Y}$

0.441

710,718
0.441

0.441

710,718
0.441

710,718

249,555

249,555

249,555

0.004 The dependent variable from column 1 to 8 is the change in the logarithm of credit granted by bank $b$ to firm $j$ during quarter $t$, whereas in column 9 , the dependent variable
is the change in the logarithm of total firm credit of firm $j$ during quarter $t$ by all banks. The dependent variable in column 10 is the logarithm of total corporate debt issuance of firm $j$ during quarter $t$ while in column 11 it refers to $\Delta \log \left(\right.$ Credit $\left._{j, t}\right)+\log \left(\left(\Delta\right.\right.$ Corporate debt $_{j, t} /$ Credit $\left.\left._{j, t}-1\right)+1\right)$ for firm $j$ during quarter $t$. The independent variable for colum $j$-11 is value of one if bank $b$ has membership to the largest fixed income platform in Germany (Eurex Exchange), and zero otherwise, which proxies for banks with higher trading expertise. 'Non-trading banks' is a binary variable that equals the value of one if bank $b$ does not have a direct Eurex Exchange membership and zero otherwise. 'Landesbank' is a binary variable that equals the value of one if bank $b$ is a Landesbank, and zero otherwise. 'Capital/TA $\mathrm{TA}_{b-1}$ ' measures the book value of equity as a fraction of total assets (in \%) for bank $b$ in quarter $t-1$. All regressions are estimated using ordinary least squares. Lagged, time-varying bank controls (Size, Interbank borrowing/TA, Deposits/TA) and fixed effects are either included (' $\mathrm{Y}$ '), not included ('N'), or spanned by another set of fixed effects ('-'). The definition of the main independent variables can be found in Table A10. A constant is included, but its coefficient is left unreported. Robust standard errors clustered at bank level following Arellano (1987) are reported in parentheses. 
TABLE 10:

INVESTMENT AND LENDING BEHAVIOR IN THE PRE-CRISIS AND POST-CRISIS PERIOD

Panel A: InVestment behavior

Dependent variable: $\Delta \mathrm{Sec} / \mathrm{TA}$

\begin{tabular}{|c|c|c|}
\hline & Pre-crisis & Post-crisis \\
\hline & $(1)$ & $(2)$ \\
\hline Trading bank $_{b}$ & $\begin{array}{l}-0.263 \\
(0.183)\end{array}$ & $\begin{array}{l}-0.049 \\
(0.135)\end{array}$ \\
\hline Landesbank $_{b}$ & $\begin{array}{l}-0.208 \\
(0.299)\end{array}$ & $\begin{array}{l}-0.118 \\
(0.122)\end{array}$ \\
\hline Bank controls & $\mathrm{Y}$ & $\mathrm{Y}$ \\
\hline Time fixed effects & $\mathrm{Y}$ & $\mathrm{Y}$ \\
\hline Observations & 2,170 & 6,451 \\
\hline R-squared & 0.018 & 0.099 \\
\hline
\end{tabular}

Panel B: Lending Behavior

Dependent variable: Change in credit

\begin{tabular}{|c|c|c|c|c|}
\hline & \multicolumn{2}{|c|}{ Pre-crisis } & \multicolumn{2}{|c|}{ Post-crisis } \\
\hline & (1) & $(2)$ & $(3)$ & $(4)$ \\
\hline 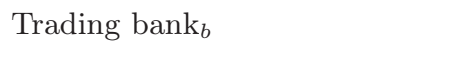 & $\begin{array}{l}-0.005 \\
(0.004)\end{array}$ & $\begin{array}{l}-0.005 \\
(0.004)\end{array}$ & $\begin{array}{c}0.007 \\
(0.006)\end{array}$ & $\begin{array}{c}0.007 \\
(0.006)\end{array}$ \\
\hline Landesbank $_{b}$ & $\begin{array}{l}-0.002 \\
(0.003)\end{array}$ & $\begin{array}{l}-0.002 \\
(0.003)\end{array}$ & $\begin{array}{l}-0.007 \\
(0.005)\end{array}$ & $\begin{array}{l}-0.007 \\
(0.005)\end{array}$ \\
\hline $\begin{array}{l}\text { Trading } \text { bank }_{b} * \\
\text { Capital/TA } \\
b, t-1\end{array}$ & $\begin{array}{c}-0.0003 \\
(0.003)\end{array}$ & $\begin{array}{c}-0.0004 \\
(0.003)\end{array}$ & $\begin{array}{c}0.002 \\
(0.003)\end{array}$ & $\begin{array}{c}0.002 \\
(0.003)\end{array}$ \\
\hline $\begin{array}{l}\text { Non-trading bank } \text { bap }^{*} \\
\text { Capital/TA } \\
b, t-1\end{array}$ & $\begin{array}{c}0.0002 \\
(0.0004)\end{array}$ & $\begin{array}{c}0.0003 \\
(0.0004)\end{array}$ & $\begin{array}{l}-0.001 \\
(0.001)\end{array}$ & $\begin{array}{l}-0.001 \\
(0.001)\end{array}$ \\
\hline Gains on pre-crisis holdings $b, t-1$ & $\begin{array}{l}-0.018 \\
(0.019)\end{array}$ & $\begin{array}{l}-0.017 \\
(0.019)\end{array}$ & $\begin{array}{c}0.007 \\
(0.008)\end{array}$ & $\begin{array}{c}0.007 \\
(0.008)\end{array}$ \\
\hline $\begin{array}{l}\text { Trading bank } \\
\text { Future Default } \\
\text { Fut }\end{array}$ & & $\begin{array}{l}-0.011 \\
(0.008)\end{array}$ & & $\begin{array}{r}-0.0002 \\
(0.006)\end{array}$ \\
\hline Bank controls & $\mathrm{Y}$ & $\mathrm{Y}$ & $\mathrm{Y}$ & $\mathrm{Y}$ \\
\hline Borrower*Time fixed effects & $\mathrm{Y}$ & $\mathrm{Y}$ & $\mathrm{Y}$ & $\mathrm{Y}$ \\
\hline Observations & 254,912 & 254,912 & 837,695 & 837,695 \\
\hline R-squared & 0.476 & 0.476 & 0.512 & 0.512 \\
\hline
\end{tabular}

The dependent variable in Panel A is the quarterly change in 'Securities holdings/TA' ( $\Delta$ Sec/TA) for each bank $b$ during quarter $t$ in the 'Pre-crisis' (2006:Q1 - 2007:Q2) and 'Post-crisis' (2010:Q1 - 2012:Q4) period. In Panel B, the dependent variable is the change in the logarithm of credit granted by bank $b$ to firm $j$ during quarter $t$. 'Trading bank' is a binary variable that equals the value of one if bank $b$ has membership to the largest fixed income platform in Germany (Eurex Exchange), and zero otherwise, which proxies for banks with higher trading expertise. 'Non-trading banks' is a binary variable that equals the value of one if bank $b$ has not a direct Eurex Exchange membership, and zero otherwise. 'Landesbank' is a binary variable that equals the value of one if bank $b$ is a Landesbank, and zero otherwise. 'Capital/TA $\mathrm{T}_{b, t-1}$ ' measures the book value of equity as a fraction of total assets (in \%) for bank $b$ in quarter $t-1$. All regressions are estimated using ordinary least squares. Lagged, time-varying bank controls (Size, Capital/TA, Interbank borrowing/TA, Deposits/TA) and fixed effects are either included (' $Y$ '), not included ('N'), or spanned by another set of fixed effects ('-'). The definition of the main independent variables can be found in Table A10. A constant is included, but its coefficient is left unreported. Robust standard errors clustered at bank level following Arellano (1987) are reported in parentheses. ***: Significant at 1 percent level; **: Significant at 5 percent level; *: Significant at 10 percent level. 


\section{APPENDIX}

\section{Figure A1:}

GreeK Government Bonds

(a) 5-year Greek sovereign CDS spread (in basis points)

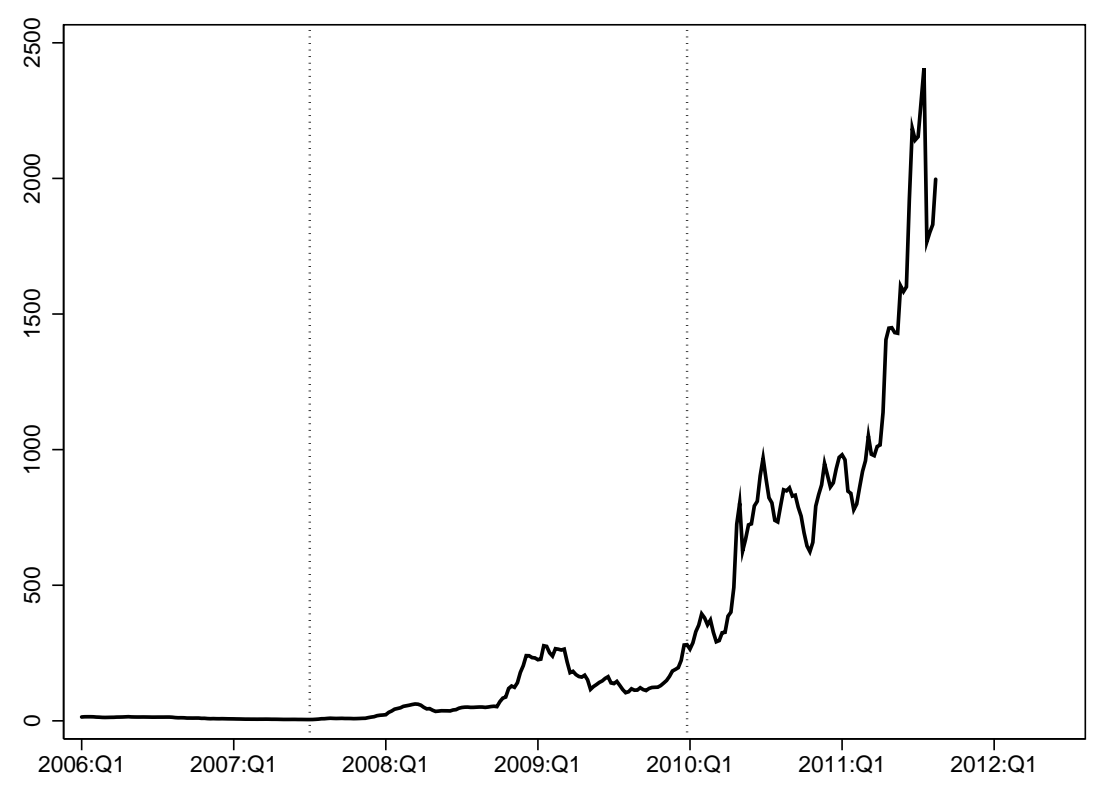

(b) Security holdings

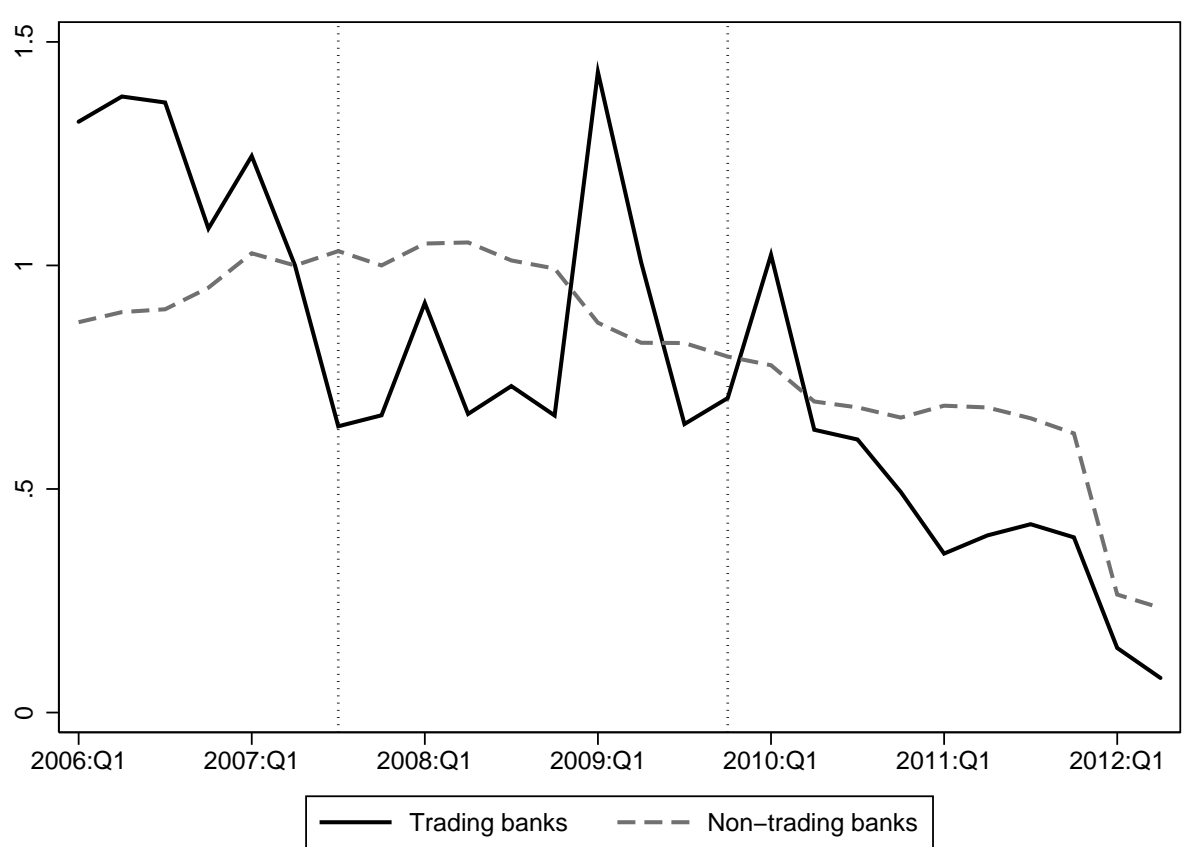

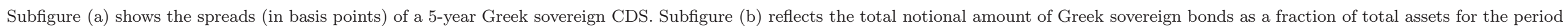

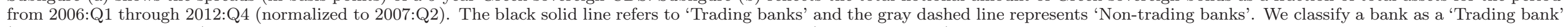

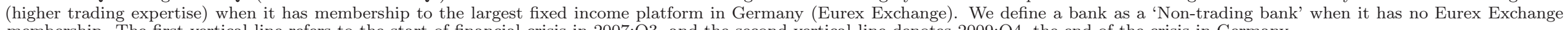
membership. The first vertical line refers to the start of financial crisis in 2007:Q3, and the second vertical line denotes 2009:Q4, the end of the crisis in Germany. 
TABLE A1:

SUMMARY STATISTICS

\begin{tabular}{|c|c|c|c|c|c|c|c|c|c|}
\hline & \multicolumn{3}{|c|}{ Pre-crisis } & \multicolumn{3}{|c|}{ Crisis } & \multicolumn{3}{|c|}{ Post-crisis } \\
\hline & Mean & Std. & Obs. & Mean & Std. & Obs. & Mean & Std. & Obs \\
\hline Securities holdings/TA & 20.41 & 5.64 & 50 & 22.29 & 6.30 & 100 & 20.19 & 6.02 & 119 \\
\hline Aaa securities & 26.35 & 14.16 & 50 & 24.98 & 14.29 & 100 & 31.62 & 14.88 & 119 \\
\hline Domestic securities & 52.18 & 16.17 & 50 & 45.44 & 15.68 & 100 & 52.70 & 14.29 & 119 \\
\hline Long-term securities & 82.54 & 8.88 & 50 & 82.44 & 10.31 & 100 & 82.82 & 10.36 & 119 \\
\hline Sovereign securities & 23.19 & 16.64 & 50 & 17.46 & 11.44 & 100 & 28.02 & 12.69 & 119 \\
\hline Off-balance sheet securities/TA & 7.20 & 4.62 & 50 & 7.78 & 4.58 & 100 & 4.69 & 2.31 & 119 \\
\hline Central bank borrowing/TA & 3.23 & 2.89 & 50 & 4.95 & 4.39 & 100 & 1.88 & 1.92 & 119 \\
\hline Buys/TA & 3.81 & 2.32 & 50 & 3.04 & 2.99 & 100 & 2.11 & 1.69 & 119 \\
\hline Sells/TA & 2.14 & 1.42 & 50 & 0.94 & 0.73 & 100 & 0.89 & 0.88 & 119 \\
\hline Loans/TA & 72.32 & 6.38 & 50 & 71.09 & 7.23 & 100 & 65.28 & 8.41 & 119 \\
\hline Capital/TA & 3.40 & 0.80 & 50 & 3.42 & 1.09 & 100 & 3.67 & 1.09 & 119 \\
\hline Size & 18.44 & 0.85 & 50 & 18.54 & 0.86 & 100 & 18.52 & 0.85 & 119 \\
\hline Gains on holdings & -0.22 & 0.12 & 50 & -0.33 & 0.31 & 100 & 0.04 & 0.24 & 119 \\
\hline Gains on pre-crisis holdings & -0.18 & 0.11 & 50 & -0.19 & 0.11 & 100 & -0.06 & 0.07 & 119 \\
\hline
\end{tabular}

This table reports the summary statistics of the variables used in the paper for Landesbanks, across three periods. We define 'Pre-crisis' (2006:Q1 - 2007:Q2), 'Crisis' (2007:Q3 - 2009:Q4), and 'Post-crisis' (2010:Q1 - 2012:Q4). 'Securities holdings/TA' measures the total investment in securities as a fraction of total assets (in \%) 'Aaa securities' measures the total investment in Aaa-rated securities as a fraction of the total investment in securities (in \%). 'Domestic securities' measures the total investment in securities with German issuer as a fraction of total investment in securities (in \%). 'Long-term securities' measures the total investment in securities with residual maturity higher than one year as a fraction of the total investment of securities (in \%). 'Sovereign securities' measures the total investment in securities issued by sovereigns as a fraction of the total investment in securities (in \%). 'Capital/TA' measures the book value of equity as a fraction of total assets (in \%). 'Size' refers to the logarithm of total assets (in thousand Euros). 'Gains on holdings' measures the (unrealized) gains/losses on all securities in the bank's portfolio as a fraction of total assets (in \%). 'Gains on pre-crisis holdings' measures the (unrealized) gains/losses on all securities in the bank's pre-crisis portfolio with maturing dates after 2009:Q4 as a fraction of total assets (in \%). The definition of the other variables can be found in Table A10. 
TABLE A1:

SUMmary STATISTICS (CONT'D)

\begin{tabular}{|c|c|c|c|c|c|c|c|c|c|}
\hline & \multicolumn{3}{|c|}{ Pre-crisis } & \multicolumn{3}{|c|}{ Crisis } & \multicolumn{3}{|c|}{ Post-crisis } \\
\hline & Mean & Std. & Obs. & Mean & Std. & Obs. & Mean & Std. & Obs. \\
\hline Gains on holdings & -0.24 & 0.29 & 150 & -0.22 & 0.40 & 296 & 0.16 & 0.41 & 353 \\
\hline Gains on pre-crisis holdings & -0.18 & 0.24 & 150 & -0.19 & 0.27 & 296 & -0.07 & 0.13 & 353 \\
\hline \multicolumn{10}{|c|}{ Panel C: Non-trading banks } \\
\hline & \multicolumn{3}{|c|}{ Pre-crisis } & \multicolumn{3}{|c|}{ Crisis } & \multicolumn{3}{|c|}{ Post-crisis } \\
\hline & Mean & Std. & Obs. & Mean & Std. & Obs. & Mean & Std. & Obs. \\
\hline Gains on holdings & -0.23 & 0.26 & 2,563 & -0.15 & 0.34 & 5,083 & 0.21 & 0.36 & 6,098 \\
\hline Gains on pre-crisis holdings & -0.14 & 0.20 & 2,563 & -0.11 & 0.20 & 5,083 & -0.02 & 0.08 & 6,098 \\
\hline
\end{tabular}

This table reports the summary statistics of the variables presented in Panel C of Table 1, across three periods. We define 'Pre-crisis' (2006:Q1 - 2007:Q2), 'Crisis' (2007:Q3 - 2009:Q4), and 'Post-crisis' (2010:Q1 - 2012:Q4). Panel A reports the summary statistics for 'Trading banks'. Panel B reports the summary statistics for 'Non-trading banks'. We classify a bank as a 'Trading bank' (higher trading expertise) when it has membership to the largest fixed income platform in Germany (Eurex Exchange). We define a bank as a 'Non-trading bank' when it has no Eurex Exchange membership. 'Gains on holdings' measures the (unrealized) gains/losses on all securities in the bank's portfolio as a fraction of total assets (in \%). 'Gains on pre-crisis holdings' measures the (unrealized) gains/losses on all securities in the bank's pre-crisis portfolio with maturing dates after 2009:Q4 as a fraction of total assets (in \%). 
TABLE A2:

BUYING BEHAVIOR DURING THE CRISIS (ALL SECURITIES) Robustness

\begin{tabular}{|c|c|c|c|c|c|}
\hline & \multicolumn{3}{|c|}{ Dependent variable } & \multicolumn{2}{|l|}{ Buys } \\
\hline & $(1)$ & $(2)$ & $(3)$ & $(4)$ & $(5)$ \\
\hline Trading bank ${ }_{b}$ & $\begin{array}{c}2.494^{* * *} \\
(0.413)\end{array}$ & $\begin{array}{c}2.618^{* * *} \\
(0.425)\end{array}$ & $\begin{array}{c}2.272^{* * *} \\
(0.377)\end{array}$ & $\begin{array}{c}2.273^{* * *} \\
(0.377)\end{array}$ & $\begin{array}{c}2.367^{* * *} \\
(0.376)\end{array}$ \\
\hline Landesbank $_{b}$ & $\begin{array}{l}1.905^{*} \\
(1.073)\end{array}$ & $\begin{array}{c}2.101^{* *} \\
(1.051)\end{array}$ & $\begin{array}{c}1.151 \\
(1.093)\end{array}$ & $\begin{array}{c}1.178 \\
(0.979)\end{array}$ & $\begin{array}{c}1.481 \\
(0.941)\end{array}$ \\
\hline Gains on pre-crisis holdings $s_{b, t-1}$ & $\begin{array}{c}0.577^{* * *} \\
(0.185)\end{array}$ & $\begin{array}{c}0.532^{* * *} \\
(0.176)\end{array}$ & $\begin{array}{c}0.647^{* * *} \\
(0.171)\end{array}$ & $\begin{array}{c}0.650^{* * *} \\
(0.171)\end{array}$ & $\begin{array}{c}0.665^{* * *} \\
(0.165)\end{array}$ \\
\hline Capital $/ \mathrm{TA}_{b, t-1}$ & $\begin{array}{l}-0.041 \\
(0.052)\end{array}$ & $\begin{array}{l}-0.042 \\
(0.053)\end{array}$ & $\begin{array}{l}-0.018 \\
(0.040)\end{array}$ & $\begin{array}{c}-0.018 \\
(0.040)\end{array}$ & $\begin{array}{l}-0.016 \\
(0.039)\end{array}$ \\
\hline Trading bank $_{b}{ }^{*}$ Gains on pre-crisis holdings ${ }_{b, t-1}$ & $\begin{array}{c}1.556^{* * *} \\
(0.556)\end{array}$ & $\begin{array}{c}1.750^{* * *} \\
(0.580)\end{array}$ & $\begin{array}{c}1.783^{* * *} \\
(0.405)\end{array}$ & $\begin{array}{c}1.780^{* * *} \\
(0.405)\end{array}$ & $\begin{array}{c}1.229^{* *} \\
(0.492)\end{array}$ \\
\hline Trading bank $_{b} *$ Capital $/ \mathrm{TA}_{b, t-1}$ & $\begin{array}{c}0.408^{* * *} \\
(0.133)\end{array}$ & $\begin{array}{c}0.450^{* * *} \\
(0.142)\end{array}$ & $\begin{array}{c}0.361^{* * *} \\
(0.120)\end{array}$ & $\begin{array}{c}0.362^{* * *} \\
(0.121)\end{array}$ & $\begin{array}{c}0.422^{* * *} \\
(0.115)\end{array}$ \\
\hline Landesbank $_{b}{ }^{*}$ Gains on pre-crisis holdings ${ }_{b, t-1}$ & $\begin{array}{l}4.879^{*} \\
(2.740)\end{array}$ & $\begin{array}{l}5.528^{*} \\
(2.831)\end{array}$ & $\begin{array}{c}2.767 \\
(3.826)\end{array}$ & $\begin{array}{c}2.782 \\
(3.740)\end{array}$ & $\begin{array}{c}2.946 \\
(2.828)\end{array}$ \\
\hline $\operatorname{Landesbank}_{b} *$ Capital/TA $\mathrm{TA}_{b, t-1}$ & $\begin{array}{l}-0.103 \\
(0.295)\end{array}$ & $\begin{array}{l}-0.084 \\
(0.287)\end{array}$ & $\begin{array}{c}-0.331 \\
(0.258)\end{array}$ & $\begin{array}{l}-0.333 \\
(0.256)\end{array}$ & $\begin{array}{l}-0.280 \\
(0.267)\end{array}$ \\
\hline Public support ${ }_{b}$ & $\begin{array}{c}1.814^{* *} \\
(0.727)\end{array}$ & & & & $\begin{array}{c}1.729^{* * *} \\
(0.548)\end{array}$ \\
\hline After public support sut, $_{b}$ & & $\begin{array}{c}1.380 * * \\
(0.666)\end{array}$ & & & \\
\hline Before public support ${ }_{b, t}$ & & $\begin{array}{c}2.398^{* * *} \\
(0.831)\end{array}$ & & & \\
\hline Central bank borrowing/ $\mathrm{TA}_{b, t-1}$ & & & $\begin{array}{c}0.001 \\
(0.006)\end{array}$ & $\begin{array}{c}0.002 \\
(0.006)\end{array}$ & $\begin{array}{c}0.003 \\
(0.006)\end{array}$ \\
\hline $\begin{array}{l}\text { Central bank borrowing } / \mathrm{TA}_{b, t-1} * \\
\text { Gains on pre-crisis holdings } \mathrm{s}_{b, t-1}\end{array}$ & & & $\begin{array}{c}0.041^{* * *} \\
(0.012)\end{array}$ & $\begin{array}{c}0.041^{* * *} \\
(0.012)\end{array}$ & $\begin{array}{c}0.041^{* * *} \\
(0.013)\end{array}$ \\
\hline Trading bank $_{b}{ }^{*}$ Central bank borrowing $/ \mathrm{TA}_{b, t-1}$ & & & $\begin{array}{c}0.069^{* * *} \\
(0.017)\end{array}$ & $\begin{array}{c}0.069^{* * *} \\
(0.016)\end{array}$ & $\begin{array}{c}0.078^{* * *} \\
(0.020)\end{array}$ \\
\hline Landesbank $_{b} *$ Central bank borrowing/ $\mathrm{TA}_{b, t-1}$ & & & & $\begin{array}{c}-0.004 \\
(0.034)\end{array}$ & $\begin{array}{l}-0.035 \\
(0.058)\end{array}$ \\
\hline Bank controls & $\mathrm{Y}$ & $\mathrm{Y}$ & $\mathrm{Y}$ & Y & $\mathrm{Y}$ \\
\hline Security*Time fixed effects & $\mathrm{Y}$ & $\mathrm{Y}$ & $\mathrm{Y}$ & $\mathrm{Y}$ & $\mathrm{Y}$ \\
\hline Observations & 281,044 & 281,044 & 281,044 & 281,044 & 281,044 \\
\hline R-squared & 0.306 & 0.307 & 0.308 & 0.308 & 0.308 \\
\hline
\end{tabular}

This table replicates Table 6 for the entire sample of securities. The dependent variable is the logarithm of the amount bought (in nominal value) by bank $b$ of security $i$ during quarter $t$, and zero otherwise. 'Trading bank' is a binary variable that equals one when bank $b$ has membership to the largest fixed income platform in Germany (Eurex Exchange), and zero otherwise, which proxies for banks with higher trading expertise. 'Landesbank' is a binary variable that equals the value of one if bank $b$ is a Landesbank, and zero otherwise. 'Capital/TA $\mathrm{T}_{b, t-1}$ ' measures the book value of equity as a fraction of total assets (in \%) for bank $b$ in quarter $t-1$. All regressions are estimated using ordinary least squares. Lagged, time-varying bank controls (Size, Interbank borrowing/TA, Deposits/TA) and fixed effects are either included ('Y'), not included ('N'), or spanned by another set of fixed effects ('-'). The definition of the main independent variables can be found in Table A10. A constant is included, but its coefficient is left unreported. Robust standard errors clustered at bank level following Arellano (1987) are reported in parentheses. ***: Significant at 1 percent level; **: Significant at 5 percent level; *: Significant at 10 percent level. 
TABle A3:

TrADING BEHAVIOR OF SECURITIES WITH THE LARGEST PRICE DROP

AND MARKET MAKING INFORMATION

Robustness

\begin{tabular}{|c|c|c|c|c|}
\hline & \multicolumn{4}{|c|}{ Dependent variable: } \\
\hline & Buys & Sells & Buys & Sells \\
\hline & $(1)$ & $(2)$ & $(3)$ & $(4)$ \\
\hline Trading bank $_{b}$ & $\begin{array}{c}1.979 * * * \\
(0.556)\end{array}$ & $\begin{array}{c}1.971^{* * *} \\
(0.704)\end{array}$ & $\begin{array}{c}1.712^{* * *} \\
(0.501)\end{array}$ & $\begin{array}{c}1.711^{* * *} \\
(0.568)\end{array}$ \\
\hline Landesbank $_{b}$ & $\begin{array}{l}1.742^{* *} \\
(0.787)\end{array}$ & $\begin{array}{l}1.379 \\
(0.955)\end{array}$ & $\begin{array}{l}1.470^{* *} \\
(0.670)\end{array}$ & $\begin{array}{l}1.081 \\
(0.737)\end{array}$ \\
\hline Bank controls & $\mathrm{Y}$ & $\mathrm{Y}$ & $\mathrm{Y}$ & $\mathrm{Y}$ \\
\hline Security*Time fixed effects & $\mathrm{N}$ & $\mathrm{N}$ & $\mathrm{Y}$ & $\mathrm{Y}$ \\
\hline $\begin{array}{l}\text { Observations } \\
\text { R-squared }\end{array}$ & $\begin{array}{l}4,919 \\
0.089\end{array}$ & $\begin{array}{l}5,004 \\
0.092\end{array}$ & $\begin{array}{l}4,919 \\
0.211\end{array}$ & $\begin{array}{l}5,004 \\
0.320\end{array}$ \\
\hline \multicolumn{5}{|c|}{$\begin{array}{l}\text { This table tests the robustness of the trading behavior to market making transactions. The sample is restricted to those } \\
\text { securities that had the largest price drop ( } 25 \text { th percentile) in the previous quarter. We restrict the sample further to } \\
\text { those securities for which we have the information on their market maker. The dependent variable for the 'Buys' is the } \\
\text { logarithm of the amount bought (in nominal value) by bank } b \text { of security } i \text { during quarter } t \text {, and zero otherwise. For } \\
\text { the 'Sells', the dependent variable is the logarithm of the amount sold (in nominal value) by bank } b \text { of security } i \text { during } \\
\text { quarter } t \text {, and zero otherwise. For each bank to calculate the buys and sells, we exclude the securities where the bank is } \\
\text { a market maker. 'Trading bank' is a binary variable that equals the value of one if bank } b \text { has membership to the largest } \\
\text { fixed income platform in Germany (Eurex Exchange), and zero otherwise, which proxies for banks with higher trading } \\
\text { expertise. 'Landesbank' is a binary variable that equals the value of one if bank } b \text { is a Landesbank, and zero otherwise. All } \\
\text { regressions are estimated using ordinary least squares. Lagged, time-varying bank controls (Size, Capital/TA, Interbank } \\
\text { borrowing/TA, Deposits/TA) and fixed effects are either included ('Y'), not included ('N'), or spanned by another set of } \\
\text { fixed effects ('-'). The definition of the main independent variables can be found in Table A10. A constant is included, } \\
\text { but its coefficient is left unreported. Robust standard errors clustered at bank level following Arellano (1987) are reported } \\
\text { in parentheses. ***: Significant at } 1 \text { percent level; **: Significant at } 5 \text { percent level; *: Significant at } 10 \text { percent level. }\end{array}$} \\
\hline
\end{tabular}


TABLE A4:

BUyiNg BEHAVIOR OF LEVEL3-RELATED SECURITIES

Robustness

\begin{tabular}{|c|c|c|c|c|}
\hline & \multicolumn{4}{|c|}{ Dependent variable: Buys } \\
\hline & $(1)$ & $(2)$ & $(3)$ & $(4)$ \\
\hline Trading bank $_{b}$ & $\begin{array}{c}1.317^{* * *} \\
(0.271)\end{array}$ & $\begin{array}{c}1.286^{* * *} \\
(0.238)\end{array}$ & $\begin{array}{c}1.458^{* * *} \\
(0.261)\end{array}$ & $\begin{array}{c}1.549^{* * *} \\
(0.459)\end{array}$ \\
\hline $\operatorname{Landesbank}_{b}$ & $\begin{array}{c}0.758^{* *} \\
(0.330)\end{array}$ & $\begin{array}{l}0.571^{*} \\
(0.332)\end{array}$ & $\begin{array}{l}0.616^{*} \\
(0.322)\end{array}$ & $\begin{array}{c}0.449 \\
(0.321)\end{array}$ \\
\hline Capital $/ \mathrm{TA}_{b, t-1}$ & $\begin{array}{c}0.071^{* *} \\
(0.032)\end{array}$ & $\begin{array}{c}0.027 \\
(0.027)\end{array}$ & $\begin{array}{c}0.030 \\
(0.027)\end{array}$ & $\begin{array}{c}0.001 \\
(0.031)\end{array}$ \\
\hline Gains on pre-crisis holdings $s_{b, t-1}$ & $\begin{array}{c}0.078 \\
(0.187)\end{array}$ & & $\begin{array}{c}0.046 \\
(0.176)\end{array}$ & \\
\hline Trading bank $_{b}{ }^{*}$ Gains on pre-crisis holdings ${ }_{b, t-1}$ & $\begin{array}{l}1.001^{*} \\
(0.559)\end{array}$ & & $\begin{array}{c}0.814 \\
(0.553)\end{array}$ & \\
\hline Trading bank $_{b}{ }^{*}$ Capital $/ \mathrm{TA}_{b, t-1}$ & & $\begin{array}{c}0.217^{* * *} \\
(0.070)\end{array}$ & $\begin{array}{c}0.192^{* * *} \\
(0.072)\end{array}$ & $\begin{array}{c}0.266^{* * *} \\
(0.075)\end{array}$ \\
\hline Tier1 buffer ${ }_{b, t-1}$ & & & & $\begin{array}{c}0.025 \\
(0.017)\end{array}$ \\
\hline $\operatorname{Trading}_{\mathrm{bank}_{b}}{ }^{*}$ Tier1 buffer $_{b, t-1}$ & & & & $\begin{array}{l}-0.048 \\
(0.051)\end{array}$ \\
\hline Bank controls & $\mathrm{Y}$ & $\mathrm{Y}$ & $\mathrm{Y}$ & $\mathrm{Y}$ \\
\hline Security*Time fixed effects & $\mathrm{Y}$ & $\mathrm{Y}$ & $\mathrm{Y}$ & $\mathrm{Y}$ \\
\hline Observations & 139,274 & 139,274 & 139,274 & 135,938 \\
\hline R-squared & 0.676 & 0.676 & 0.676 & 0.680 \\
\hline
\end{tabular}

This table tests the robustness of the trading behavior to Level 3 securities, i.e. securities with no market price. That is, we proxy Level 3 securities using securities with no market price. The dependent variable is the logarithm of the amount bought (in nominal value) by bank $b$ of security $i$ during quarter $t$, and zero otherwise. 'Trading bank' is a binary variable that equals one when bank $b$ has membership to the largest fixed income platform in Germany (Eurex Exchange), and zero otherwise, which proxies for banks with higher trading expertise. 'Landesbank' is a binary variable that equals the value of one if bank $b$ is a Landesbank, and zero otherwise. 'Capital/ $\mathrm{TA}_{b, t-1}$ ' measures the book value of equity as a fraction of total assets (in \%) for bank $b$ in quarter $t-1$. All regressions are estimated using ordinary least squares. Lagged, time-varying bank controls (Size, Interbank borrowing/TA, Deposits/TA) and fixed effects are either included ('Y'), not included ('N'), or spanned by another set of fixed effects ('-'). The definition of the main independent variables can be found in Table A10. A constant is included, but its coefficient is left unreported. Robust standard errors clustered at bank level following Arellano (1987) are reported in parentheses. ${ }^{* * *}$ : Significant at 1 percent level; **: Significant at 5 percent level; *: Significant at 10 percent level. 
TABLE A5:

TradiNg BeHAVIOR OF SECURITIES WITH THE LARGEST PRICE DROP

Robustness

\begin{tabular}{|c|c|c|c|c|}
\hline & \multicolumn{4}{|c|}{ Dependent variable: } \\
\hline & Buys & Sells & Buys & Sells \\
\hline & (1) & $(2)$ & $(3)$ & $(4)$ \\
\hline Trading $\operatorname{bank}_{b}$ & $\begin{array}{c}2.893^{* * * *} \\
(0.450)\end{array}$ & $\begin{array}{c}3.431^{* * *} \\
(0.458)\end{array}$ & $\begin{array}{c}3.152^{* * *} \\
(0.471)\end{array}$ & $\begin{array}{c}3.585^{* * *} \\
(0.518)\end{array}$ \\
\hline Landesbank $_{b}$ & $\begin{array}{c}2.564^{* * *} \\
(0.474)\end{array}$ & $\begin{array}{c}2.660^{* * *} \\
(0.381)\end{array}$ & $\begin{array}{c}2.549^{* * *} \\
(0.467)\end{array}$ & $\begin{array}{c}2.636^{* * *} \\
(0.370)\end{array}$ \\
\hline$\Delta$ Credit $/ \mathrm{TA}_{b, t-1}$ & $\begin{array}{c}0.036 \\
(0.031)\end{array}$ & $\begin{array}{l}-0.003 \\
(0.023)\end{array}$ & $\begin{array}{c}0.031 \\
(0.039)\end{array}$ & $\begin{array}{c}0.006 \\
(0.023)\end{array}$ \\
\hline Capital $/ \mathrm{TA}_{b, t-1}$ & $\begin{array}{c}0.047 \\
(0.049)\end{array}$ & $\begin{array}{c}0.025 \\
(0.021)\end{array}$ & $\begin{array}{c}0.065 \\
(0.059)\end{array}$ & $\begin{array}{c}0.045 \\
(0.029)\end{array}$ \\
\hline Capital $/ \mathrm{TA}_{b, t-1} * \Delta$ Credit $/ \mathrm{TA}_{b, t-1}$ & $\begin{array}{l}-0.009 \\
(0.016)\end{array}$ & $\begin{array}{l}-0.005 \\
(0.014)\end{array}$ & $\begin{array}{l}-0.007 \\
(0.017)\end{array}$ & $\begin{array}{l}-0.001 \\
(0.015)\end{array}$ \\
\hline Trading $\operatorname{bank}_{b} * \Delta$ Credit $/ \mathrm{TA}_{b, t-1}$ & $\begin{array}{c}-0.156^{* * *} \\
(0.054)\end{array}$ & $\begin{array}{c}0.048 \\
(0.073)\end{array}$ & $\begin{array}{c}-0.140 * * \\
(0.065)\end{array}$ & $\begin{array}{c}0.017 \\
(0.096)\end{array}$ \\
\hline Landesbank $_{b} * \Delta$ Credit/TA $\mathrm{TA}_{b, t-1}$ & $\begin{array}{c}-0.064 \\
(0.063)\end{array}$ & $\begin{array}{c}0.072 \\
(0.056)\end{array}$ & $\begin{array}{l}-0.069 \\
(0.064)\end{array}$ & $\begin{array}{c}0.077 \\
(0.059)\end{array}$ \\
\hline Trading bank $_{b}{ }^{*}$ Capital $/ \mathrm{TA}_{b, t-1}$ & $\begin{array}{c}0.253 \\
(0.160)\end{array}$ & $\begin{array}{c}0.263 \\
(0.162)\end{array}$ & $\begin{array}{c}0.166 \\
(0.153)\end{array}$ & $\begin{array}{c}0.183 \\
(0.159)\end{array}$ \\
\hline $\begin{array}{l}\text { Trading } \text { bank }_{b} * \text { Capital } / \mathrm{TA}_{b, t-1} * \\
\Delta \text { Credit } / \mathrm{TA}_{b, t-1}\end{array}$ & $\begin{array}{c}-0.069^{* *} \\
(0.032)\end{array}$ & $\begin{array}{l}-0.030 \\
(0.046)\end{array}$ & $\begin{array}{c}-0.071^{* *} \\
(0.030)\end{array}$ & $\begin{array}{l}-0.028 \\
(0.049)\end{array}$ \\
\hline Gains on pre-crisis holdings $b, t-1$ & & & $\begin{array}{r}0.577^{* *} \\
(0.250)\end{array}$ & $\begin{array}{c}0.636^{* * *} \\
(0.235)\end{array}$ \\
\hline Gains on pre-crisis holdings $s_{b, t-1} * \Delta$ Credit $/ \mathrm{TA}_{b, t-1}$ & & & $\begin{array}{l}-0.039 \\
(0.082)\end{array}$ & $\begin{array}{c}0.031 \\
(0.099)\end{array}$ \\
\hline Trading $\operatorname{bank}_{b}{ }^{*}$ Gains on pre-crisis holdings $b, t-1$ & & & $\begin{array}{l}2.175^{* * *} \\
(0.799)\end{array}$ & $\begin{array}{c}1.568 \\
(1.203)\end{array}$ \\
\hline $\begin{array}{l}\text { Trading } \text { bank }_{b} * \text { Gains on pre-crisis holdings } \\
\Delta \text { Credit } / \mathrm{TA}_{b, t-1} *\end{array}$ & & & $\begin{array}{c}0.174 \\
(0.169)\end{array}$ & $\begin{array}{l}-0.089 \\
(0.248)\end{array}$ \\
\hline Bank controls & $\mathrm{Y}$ & $\mathrm{Y}$ & $\mathrm{Y}$ & $\mathrm{Y}$ \\
\hline Security*Time fixed effects & $\mathrm{Y}$ & $\mathrm{Y}$ & $\mathrm{Y}$ & $\mathrm{Y}$ \\
\hline Observations & 79,530 & 83,090 & 79,530 & 83,090 \\
\hline R-squared & 0.293 & 0.401 & 0.297 & 0.403 \\
\hline
\end{tabular}

This table tests the robustness of the trading behavior to change in credit at the bank level. The sample is restricted to those securities that had the largest price drop (25th percentile) in the previous quarter. The dependent variable for the 'Buys' is the logarithm of the amount bought (in nominal value) by bank $b$ of security $i$ during quarter $t$, and zero otherwise. For the 'Sells', the dependent variable is the logarithm of the amount sold (in nominal value) by bank $b$ of security $i$ during quarter $t$, and zero otherwise. 'Trading bank' is a binary variable that equals the value of one if bank $b$ has membership to the largest fixed income platform in Germany (Eurex Exchange), and zero otherwise, which proxies for banks with higher trading expertise. 'Landesbank' is a binary variable that equals the value of one if bank $b$ is a Landesbank, and zero otherwise. 'Capital $/ \mathrm{TA}_{b, t-1}$ ' measures the book value of equity as a fraction of total assets (in $\%$ ) for bank $b$ in quarter $t-1$. ' $\Delta$ Credit/ $\mathrm{TA}_{b, t-1}$ ' measures the change in total amount of credit as a fraction of total assets (in \%) for bank $b$ in quarter $t-1$. All regressions are estimated using ordinary least squares. Lagged, time-varying bank controls (Size, Interbank borrowing/TA, Deposits/TA) and fixed effects are either included (' $\mathrm{Y}$ '), not included ('N'), or spanned by another set of fixed effects ('-'). The definition of the main independent variables can be found in Table A10. A constant is included, but its coefficient is left unreported. Robust standard errors clustered at bank level following Arellano (1987) are reported in parentheses. ***: Significant at 1 percent level; **: Significant at 5 percent level; *: Significant at 10 percent level. 
TABLE A6:

BUying BEHAVIOR OF SECURITIES WITH THE LARGEST PRICE DROP (EACH QUARTER)

Robustness

\begin{tabular}{|c|c|c|c|c|c|c|c|c|c|c|}
\hline & 2007:Q3 & 2007:Q4 & 2008:Q1 & 2008:Q2 & 2008:Q3 & 2008:Q4 & 2009:Q1 & 2009:Q2 & 2009:Q3 & 2009:Q4 \\
\hline & (1) & $(2)$ & (3) & (4) & $(5)$ & (6) & $(7)$ & $(8)$ & (9) & (10) \\
\hline Trading bank $_{b}$ & $\begin{array}{c}3.257^{* * *} \\
(0.915)\end{array}$ & $\begin{array}{c}1.570^{* * *} \\
(0.528)\end{array}$ & $\begin{array}{c}1.070^{* *} \\
(0.518)\end{array}$ & $\begin{array}{c}0.640 \\
(0.504)\end{array}$ & $\begin{array}{c}1.448^{* * *} \\
(0.545)\end{array}$ & $\begin{array}{c}1.008^{* * *} \\
(0.335)\end{array}$ & $\begin{array}{c}0.816^{* * *} \\
(0.302)\end{array}$ & $\begin{array}{c}0.660 \\
(0.427)\end{array}$ & $\begin{array}{c}1.912^{* * *} \\
(0.578)\end{array}$ & $\begin{array}{c}1.669^{* * *} \\
(0.627)\end{array}$ \\
\hline Landesbank $_{b}$ & $\begin{array}{c}2.903^{* * *} \\
(0.876)\end{array}$ & $\begin{array}{l}1.154^{*} \\
(0.612)\end{array}$ & $\begin{array}{c}0.708 \\
(0.558)\end{array}$ & $\begin{array}{c}1.103 \\
(0.779)\end{array}$ & $\begin{array}{l}1.392^{* *} \\
(0.634)\end{array}$ & $\begin{array}{c}0.860^{* *} \\
(0.414)\end{array}$ & $\begin{array}{c}0.447 \\
(0.543)\end{array}$ & $\begin{array}{c}0.200 \\
(0.464)\end{array}$ & $\begin{array}{c}2.105^{* * *} \\
(0.658)\end{array}$ & $\begin{array}{c}2.236^{* *} \\
(0.935)\end{array}$ \\
\hline Bank controls & $\mathrm{Y}$ & $\mathrm{Y}$ & $\mathrm{Y}$ & $\mathrm{Y}$ & $\mathrm{Y}$ & $\mathrm{Y}$ & $\mathrm{Y}$ & $\mathrm{Y}$ & $\mathrm{Y}$ & $\mathrm{Y}$ \\
\hline Security fixed effects & $\mathrm{Y}$ & $\mathrm{Y}$ & $\mathrm{Y}$ & $\mathrm{Y}$ & $\mathrm{Y}$ & $\mathrm{Y}$ & $\mathrm{Y}$ & $\mathrm{Y}$ & $\mathrm{Y}$ & $\mathrm{Y}$ \\
\hline Observations & 8,054 & 7,786 & 7,623 & 7,856 & 7,971 & 7,471 & 7,401 & 7,414 & 8,790 & 9,164 \\
\hline R-squared & 0.273 & 0.277 & 0.248 & 0.350 & 0.276 & 0.367 & 0.364 & 0.312 & 0.278 & 0.311 \\
\hline
\end{tabular}

The dependent variable is the logarithm of the amount bought (in nominal value) by bank $b$ of security $i$ during quarter $t$ if the amount is positive, and zero otherwise. 'Trading bank' is a binary variable that equals the value of one if bank $b$ has membership to the largest fixed income platform in Germany (Eurex Exchange), and zero otherwise, which proxies for banks with higher trading expertise. 'Landesbank' is a binary variable that equals the value of one if bank $b$ is a Landesbank, and zero otherwise. All regressions are estimated using ordinary least squares. Lagged, time-varying bank controls (Size, Capital/TA, Interbank borrowing/TA, Deposits/TA) and fixed effects are either included ('Y'), not included ('N'), or spanned by another set of fixed effects ('-'). The definition of the main independent variables can be found in Table A10. A constant is included, but its coefficient is left unreported. Robust standard errors clustered at bank level following Arellano (1987) are reported in parentheses. ${ }^{* *}$ : Significant at 1 percent level; **: Significant at 5 percent level; *: Significant at 10 percent level. 
TABLE A7:

SELliNg BEHAVIOR DURING THE CRISIS (ALL SECURITIES) Robustness

\begin{tabular}{|c|c|c|c|c|c|c|}
\hline & \multicolumn{6}{|c|}{ Dependent variable: Sells } \\
\hline & (1) & $(2)$ & $(3)$ & (4) & $(5)$ & (6) \\
\hline Trading bank $_{b}$ & $\begin{array}{c}1.921^{* * *} \\
(0.353)\end{array}$ & $\begin{array}{c}1.939 * * * \\
(0.351)\end{array}$ & $\begin{array}{c}1.994^{* * *} \\
(0.358)\end{array}$ & $\begin{array}{c}1.914^{* * *} \\
(0.350)\end{array}$ & $\begin{array}{c}1.786^{* * *} \\
(0.349)\end{array}$ & $\begin{array}{c}1.726^{* * *} \\
(0.391)\end{array}$ \\
\hline Landesbank $_{b}$ & $\begin{array}{c}1.626^{* * *} \\
(0.563)\end{array}$ & $\begin{array}{l}1.562^{*} \\
(0.897)\end{array}$ & $\begin{array}{l}1.719^{* *} \\
(0.870)\end{array}$ & $\begin{array}{c}1.576^{* * *} \\
(0.550)\end{array}$ & $\begin{array}{l}1.371^{* *} \\
(0.550)\end{array}$ & $\begin{array}{l}1.260 \\
(0.847)\end{array}$ \\
\hline Capital $/ \mathrm{TA}_{b, t-1}$ & $\begin{array}{l}-0.043 \\
(0.047)\end{array}$ & $\begin{array}{l}-0.041 \\
(0.046)\end{array}$ & $\begin{array}{l}-0.042 \\
(0.047)\end{array}$ & $\begin{array}{l}-0.041 \\
(0.050)\end{array}$ & $\begin{array}{l}-0.010 \\
(0.049)\end{array}$ & $\begin{array}{l}-0.011 \\
(0.048)\end{array}$ \\
\hline $\begin{array}{l}\text { Trading } \text { bank }_{b} * \\
\text { Capital } / \mathrm{TA}_{b, t-1}\end{array}$ & $\begin{array}{c}0.248^{* *} \\
(0.116)\end{array}$ & $\begin{array}{l}0.252^{* *} \\
(0.119)\end{array}$ & $\begin{array}{c}0.267^{* *} \\
(0.119)\end{array}$ & $\begin{array}{c}0.246^{* *} \\
(0.116)\end{array}$ & $\begin{array}{l}0.202^{*} \\
(0.109)\end{array}$ & $\begin{array}{c}0.223^{* *} \\
(0.111)\end{array}$ \\
\hline Gains on pre-crisis holdings $s_{b, t-1}$ & $\begin{array}{c}0.803^{* * *} \\
(0.196)\end{array}$ & $\begin{array}{c}0.793^{* * *} \\
(0.189)\end{array}$ & $\begin{array}{c}0.726^{* * *} \\
(0.177)\end{array}$ & $\begin{array}{c}0.817^{* * *} \\
(0.203)\end{array}$ & $\begin{array}{c}1.080^{* * *} \\
(0.214)\end{array}$ & $\begin{array}{c}1.017^{* * *} \\
(0.211)\end{array}$ \\
\hline $\begin{array}{l}\text { Trading bank }{ }^{*} \\
\text { Gains on pre-crisis holdings } s_{b, t-1}\end{array}$ & $\begin{array}{c}0.085 \\
(0.846)\end{array}$ & $\begin{array}{l}-0.085 \\
(0.771)\end{array}$ & $\begin{array}{c}0.168 \\
(0.793)\end{array}$ & $\begin{array}{c}0.031 \\
(0.878)\end{array}$ & $\begin{array}{c}0.032 \\
(0.791)\end{array}$ & $\begin{array}{l}0.916 \\
(1.142)\end{array}$ \\
\hline $\begin{array}{l}\text { Landesbank }_{b}^{*} \\
\text { Gains on pre-crisis holdings }{ }_{b, t-1}\end{array}$ & $\begin{array}{l}1.656 \\
(2.073)\end{array}$ & $\begin{array}{c}1.524 \\
(1.940)\end{array}$ & $\begin{array}{c}2.181 \\
(1.911)\end{array}$ & $\begin{array}{c}1.614 \\
(2.158)\end{array}$ & $\begin{array}{c}0.933 \\
(2.125)\end{array}$ & $\begin{array}{l}1.734 \\
(2.236)\end{array}$ \\
\hline $\begin{array}{l}\text { Landesbank }{ }_{b}^{*} \\
\text { Capital/TA } / \mathrm{TA}_{b, t-1}\end{array}$ & $\begin{array}{c}0.079 \\
(0.191)\end{array}$ & $\begin{array}{c}0.130 \\
(0.231)\end{array}$ & $\begin{array}{c}0.174 \\
(0.218)\end{array}$ & $\begin{array}{c}0.088 \\
(0.191)\end{array}$ & $\begin{array}{c}0.055 \\
(0.188)\end{array}$ & $\begin{array}{c}0.132 \\
(0.237)\end{array}$ \\
\hline Public support ${ }_{b}$ & & $\begin{array}{c}1.802^{* * *} \\
(0.521)\end{array}$ & & & & $\begin{array}{c}1.627^{* * * *} \\
(0.488)\end{array}$ \\
\hline After public support ${ }_{b, t}$ & & & $\begin{array}{c}1.487 * * * \\
(0.492)\end{array}$ & & & \\
\hline Before public support ${ }_{b, t}$ & & & $\begin{array}{c}2.130^{* * *} \\
(0.573)\end{array}$ & & & \\
\hline Central bank borrowing/ $\mathrm{TA}_{b, t-1}$ & & & & $\begin{array}{c}0.022^{* *} \\
(0.011)\end{array}$ & $\begin{array}{c}0.033^{* * *} \\
(0.013)\end{array}$ & $\begin{array}{c}0.033^{* * *} \\
(0.012)\end{array}$ \\
\hline $\begin{array}{l}\text { Central bank borrowing } / \mathrm{TA}_{b} * \\
\text { Gains on pre-crisis holdings }{ }_{b, t-1}\end{array}$ & & & & & $\begin{array}{c}0.050^{* * *} \\
(0.017)\end{array}$ & $\begin{array}{c}0.051^{* * *} \\
(0.016)\end{array}$ \\
\hline $\begin{array}{l}\text { Public support }_{b}{ }^{*} \\
\text { Gains on pre-crisis holdings }{ }_{b, t-1}\end{array}$ & & & & & & $\begin{array}{c}0.727 \\
(0.930) \\
\end{array}$ \\
\hline Bank controls & $\mathrm{Y}$ & $\mathrm{Y}$ & $\mathrm{Y}$ & $\mathrm{Y}$ & $\mathrm{Y}$ & $\mathrm{Y}$ \\
\hline Security*Time fixed effects & $\mathrm{Y}$ & $\mathrm{Y}$ & $\mathrm{Y}$ & $\mathrm{Y}$ & $\mathrm{Y}$ & $\mathrm{Y}$ \\
\hline Observations & 319,070 & 319,070 & 319,070 & 319,070 & 319,070 & 319,070 \\
\hline R-squared & 0.434 & 0.434 & 0.434 & 0.434 & 0.435 & 0.435 \\
\hline
\end{tabular}

This table replicates Table 7 for the entire sample of securities. The dependent variable is the logarithm of the amount sold (in nominal value) by bank $b$ of security $i$ during quarter $t$, and zero otherwise. 'Trading bank' is a binary variable that equals one when bank $b$ has membership to the largest fixed income platform in Germany (Eurex Exchange), and zero otherwise, which proxies for banks with higher trading expertise. 'Landesbank' is a binary variable that equals the value of one if bank $b$ is a Landesbank, and zero otherwise. 'Capital $/ \mathrm{TA}_{b, t-1}$ ' measures the book value of equity as a fraction of total assets (in \%) for bank $b$ in quarter $t-1$. All regressions are estimated using ordinary least squares. Lagged, time-varying bank controls (Size, Interbank borrowing/TA, Deposits/TA) and fixed effects are either included (' $\mathrm{Y}$ '), not included ('N'), or spanned by another set of fixed effects ('-'). The definition of the main independent variables can be found in Table A10. A constant is included, but its coefficient is left unreported. Robust standard errors clustered at bank level following Arellano (1987) are reported in parentheses. ***: Significant at 1 percent level; **: Significant at 5 percent level; *: Significant at 10 percent level. 
TABLE A8:

BUYING BEHAVIOR DURING THE CRISIS ACROSS SECURITIES

RoBustness

PANel A: Buying Behavior of SECURities With the largest PRice drop

\begin{tabular}{|c|c|c|c|c|}
\hline & \multicolumn{4}{|c|}{ Dependent variable: Buys } \\
\hline & Aaa-rated & Below Aaa-rated & Up to 1 Year & Above 1 Year \\
\hline & (1) & $(2)$ & $(3)$ & (4) \\
\hline Trading bank $_{b}$ & $\begin{array}{c}1.629^{* * *} \\
(0.462)\end{array}$ & $\begin{array}{c}1.347^{* * *} \\
(0.423)\end{array}$ & $\begin{array}{c}1.608^{* * *} \\
(0.481)\end{array}$ & $\begin{array}{c}1.312^{* * *} \\
(0.407)\end{array}$ \\
\hline Landesbank $_{b}$ & $\begin{array}{c}1.816^{* *} \\
(0.717)\end{array}$ & $\begin{array}{c}1.179^{* *} \\
(0.512)\end{array}$ & $\begin{array}{c}2.088^{* * * *} \\
(0.697)\end{array}$ & $\begin{array}{c}1.131^{* *} \\
(0.486)\end{array}$ \\
\hline Bank controls & $\mathrm{Y}$ & $\mathrm{Y}$ & $\mathrm{Y}$ & $\mathrm{Y}$ \\
\hline Security*Time fixed effects & $\mathrm{Y}$ & $\mathrm{Y}$ & $\mathrm{Y}$ & $\mathrm{Y}$ \\
\hline Observations & 16,164 & 63,366 & 10,462 & 69,068 \\
\hline R-squared & 0.298 & 0.293 & 0.337 & 0.292 \\
\hline
\end{tabular}

Panel B: Buying Behavior of All securities

Dependent variable: Buys

\begin{tabular}{|c|c|c|c|c|}
\hline & Aaa-rated & Below Aaa-rated & Up to 1 Year & Above 1 Yea \\
\hline & (1) & $(2)$ & $(3)$ & (4) \\
\hline Trading bank $_{b}$ & $\begin{array}{c}1.751^{* * *} \\
(0.480)\end{array}$ & $\begin{array}{c}1.708^{* * *} \\
(0.479)\end{array}$ & $\begin{array}{c}1.946^{* * *} \\
(0.474)\end{array}$ & $\begin{array}{c}1.618^{* * *} \\
(0.497)\end{array}$ \\
\hline Landesbank $_{b}$ & $\begin{array}{c}1.605^{* *} \\
(0.702)\end{array}$ & $\begin{array}{c}1.417^{* *} \\
(0.583)\end{array}$ & $\begin{array}{c}1.805^{* * *} \\
(0.679)\end{array}$ & $\begin{array}{c}1.343^{* *} \\
(0.576)\end{array}$ \\
\hline Bank controls & $\mathrm{Y}$ & $\mathrm{Y}$ & $\mathrm{Y}$ & $\mathrm{Y}$ \\
\hline Security*Time fixed effects & $\mathrm{Y}$ & $\mathrm{Y}$ & $\mathrm{Y}$ & $\mathrm{Y}$ \\
\hline Observations & 77,943 & 228,016 & 54,769 & 251,190 \\
\hline R-squared & 0.284 & 0.286 & 0.311 & 0.284 \\
\hline
\end{tabular}

This table reports the buying behavior of banks, split by different ratings and maturities. In Panel A, the sample is restricted to those securities that had the largest price drop (25th percentile) in the previous quarter. Panel B replicates Panel A for the entire sample of securities. The dependent variable is the logarithm of the amount bought (in nominal value) by bank $b$ of security $i$ during quarter $t$, and zero otherwise. The splits are based on ratings and remaining residual maturity of the securities. 'Trading bank' is a binary variable that equals the value of one if bank $b$ has membership to the largest fixed income platform in Germany (Eurex Exchange), and zero otherwise, which proxies for banks with higher trading expertise. 'Landesbank' is a binary variable that equals the value of one if bank $b$ is a Landesbank, and zero otherwise. All regressions are estimated using ordinary least squares. Lagged, time-varying bank controls (Size, Capital/TA, Interbank borrowing/TA, Deposits/TA) and fixed effects are either included (' $\mathrm{Y}$ '), not included ('N'), or spanned by another set of fixed effects ('-'). The definition of the main independent variables can be found in Table A10. A constant is included, but its coefficient is left unreported. Robust standard errors clustered at bank level following Arellano (1987) are reported in parentheses. ***: Significant at 1 percent level; **: Significant at 5 percent level; *: Significant at 10 percent level. 
TABLE A9:

LENDING BEHAVIOR DURING THE CRISIS

Robustness

\begin{tabular}{|c|c|c|c|c|}
\hline & \multicolumn{4}{|c|}{ Dependent variable: Change in credit } \\
\hline & $(1)$ & $(2)$ & $(3)$ & $(4)$ \\
\hline Trading bank $_{b}$ & $\begin{array}{c}-0.062^{* * *} \\
(0.021)\end{array}$ & $\begin{array}{c}-0.055^{* * *} \\
(0.019)\end{array}$ & $\begin{array}{c}-0.062^{* * *} \\
(0.021)\end{array}$ & $\begin{array}{r}-0.039^{*} \\
(0.020)\end{array}$ \\
\hline Landesbank $_{b}$ & $\begin{array}{l}-0.018 \\
(0.025)\end{array}$ & $\begin{array}{c}0.001 \\
(0.020)\end{array}$ & $\begin{array}{l}-0.009 \\
(0.023)\end{array}$ & $\begin{array}{c}0.018 \\
(0.022)\end{array}$ \\
\hline $\begin{array}{l}\text { Trading } \operatorname{bank}_{b} * \\
\text { Capital } / \mathrm{TA}_{b, t-1}\end{array}$ & $\begin{array}{l}-0.010^{*} \\
(0.005)\end{array}$ & $\begin{array}{l}-0.009 * \\
(0.005)\end{array}$ & $\begin{array}{l}-0.009 * \\
(0.006)\end{array}$ & $\begin{array}{l}-0.007 \\
(0.006)\end{array}$ \\
\hline $\begin{array}{l}\text { Non-trading } \text { bank }_{b} * \\
\text { Capital } / \mathrm{TA}_{b, t-1}\end{array}$ & $\begin{array}{l}-0.000 \\
(0.003)\end{array}$ & $\begin{array}{l}-0.000 \\
(0.003)\end{array}$ & $\begin{array}{l}-0.000 \\
(0.003)\end{array}$ & $\begin{array}{l}-0.002 \\
(0.003)\end{array}$ \\
\hline $\begin{array}{l}\text { Landesbank }_{b} * \\
\text { Capital } / \mathrm{TA}_{b, t-1}\end{array}$ & $\begin{array}{l}-0.007 \\
(0.008)\end{array}$ & $\begin{array}{l}-0.009 \\
(0.009)\end{array}$ & $\begin{array}{l}-0.005 \\
(0.008)\end{array}$ & $\begin{array}{c}0.015 \\
(0.014)\end{array}$ \\
\hline $\begin{array}{l}\text { Trading } \text { bank }_{b} * \\
\text { Gains on pre-crisis holdings } b, t-1\end{array}$ & $\begin{array}{l}-0.009 \\
(0.128)\end{array}$ & & $\begin{array}{l}-0.010 \\
(0.128)\end{array}$ & $\begin{array}{l}-0.021 \\
(0.127)\end{array}$ \\
\hline $\begin{array}{l}\text { Non-trading } \text { bank }_{b}{ }^{*} \\
\text { Gains on pre-crisis holdings } b, t-1\end{array}$ & $\begin{array}{c}0.056 \\
(0.040)\end{array}$ & & $\begin{array}{c}0.059 \\
(0.040)\end{array}$ & $\begin{array}{c}0.065 \\
(0.040)\end{array}$ \\
\hline $\begin{array}{l}\text { Landesbank }_{b}{ }^{*} \\
\text { Gains on pre-crisis holdings } \\
b, t-1\end{array}$ & $\begin{array}{l}-0.210 \\
(0.168)\end{array}$ & & $\begin{array}{l}-0.222 \\
(0.170)\end{array}$ & $\begin{array}{l}-0.187 \\
(0.176)\end{array}$ \\
\hline $\begin{array}{l}\text { Trading bank }{ }^{*} \\
\text { Central bank borrowing } / \mathrm{TA}_{b, t-1}\end{array}$ & & $\begin{array}{l}-0.000 \\
(0.001)\end{array}$ & $\begin{array}{l}-0.000 \\
(0.001)\end{array}$ & $\begin{array}{c}0.001 \\
(0.001)\end{array}$ \\
\hline $\begin{array}{l}\text { Non-trading bank }{ }^{*} \\
\text { Central bank borrowing } / \mathrm{TA}_{b, t-1}\end{array}$ & & $\begin{array}{c}0.001 \\
(0.001)\end{array}$ & $\begin{array}{c}0.000 \\
(0.001)\end{array}$ & $\begin{array}{c}0.001 \\
(0.001)\end{array}$ \\
\hline $\begin{array}{l}\text { Landesbank }_{b}{ }^{*} \\
\text { Central bank borrowing/ } \mathrm{TA}_{b, t-1}\end{array}$ & & $\begin{array}{l}-0.001 \\
(0.001)\end{array}$ & $\begin{array}{l}-0.002 \\
(0.001)\end{array}$ & $\begin{array}{l}-0.001 \\
(0.001)\end{array}$ \\
\hline Public support ${ }_{b}$ & & & & $\begin{array}{c}-0.051^{* * *} \\
(0.016)\end{array}$ \\
\hline Bank controls & $\mathrm{Y}$ & $\mathrm{Y}$ & $\mathrm{Y}$ & $\mathrm{Y}$ \\
\hline Borrower*Time fixed effects & $\mathrm{Y}$ & $\mathrm{Y}$ & $\mathrm{Y}$ & $\mathrm{Y}$ \\
\hline Observations & 710,718 & 710,718 & 710,718 & 710,718 \\
\hline R-squared & 0.441 & 0.441 & 0.441 & 0.441 \\
\hline
\end{tabular}

The dependent variable is the change in the logarithm of credit granted by bank $b$ to firm $j$ during quarter $t$. 'Trading bank' is a binary variable that equals the value of one if bank $b$ has membership to the largest fixed income platform in Germany (Eurex Exchange), and zero otherwise, which proxies for banks with higher trading expertise. 'Non-trading banks' is a binary variable that equals the value of one if bank $b$ does not have a direct Eurex Exchange membership and zero otherwise. 'Landesbank' is a binary variable that equals the value of one if bank $b$ is a Landesbank, and zero otherwise. 'Capital/ $\mathrm{TA}_{b, t-1}$ ' measures the book value of equity as a fraction of total assets (in \%) for bank $b$ in quarter $t-1$. All regressions are estimated using ordinary least squares. Lagged, time-varying bank controls (Size, Interbank borrowing/TA, Deposits/TA) and fixed effects are either included (' $\mathrm{Y}$ '), not included (' $\mathrm{N}$ '), or spanned by another set of fixed effects ('-'). The definition of the main independent variables can be found in Table A10. A constant is included, but its coefficient is left unreported. Robust standard errors clustered at bank level following Arellano (1987) are reported in parentheses. ***: Significant at 1 percent level; **: Significant at 5 percent level; *: Significant at 10 percent level. 
TABle A10:

CORPORATE DEBT ISSUANCE DURING THE CRISIS

RoBustness

\begin{tabular}{|c|c|c|c|c|}
\hline \multirow[b]{3}{*}{ Change in credit $_{b, t}$} & \multicolumn{4}{|c|}{ Dependent variable: Corporate debt issuance } \\
\hline & $(1)$ & $(2)$ & $(3)$ & $(4)$ \\
\hline & $\begin{array}{c}0.001 \\
(0.001)\end{array}$ & & $\begin{array}{c}0.001 \\
(0.001)\end{array}$ & \\
\hline Change in $\operatorname{credit}_{b, t-1}$ & & $\begin{array}{l}-0.001 \\
(0.001)\end{array}$ & & $\begin{array}{c}-0.001 \\
(0.001)\end{array}$ \\
\hline Time fixed effects & $\mathrm{Y}$ & $\mathrm{Y}$ & $\mathrm{Y}$ & $\mathrm{Y}$ \\
\hline Observations & 249,555 & 249,555 & 249,555 & 249,555 \\
\hline R-squared & 0.000 & 0.000 & 0.000 & 0.000 \\
\hline
\end{tabular}

The dependent variable in column 1 and 2 is a binary variable that equals the value of one when firm $j$ issues corporate debt during quarter $t$, and zero otherwise. In column 3 and 4 , the dependent variable is the logarithm of corporate bond issuance by firm $j$ during quarter $t$. A constant is included, but its coefficient is left unreported. Robust standard errors clustered at firm level following Arellano (1987) are reported in parentheses. ***: Significant at 1 percent level; **: Significant at 5 percent level; *: Significant at 10 percent level. 
TABLE A11:

DEFINITION OF MAIN INDEPENDENT VARIABLES

\begin{tabular}{|c|c|}
\hline Variable name & Definition \\
\hline Trading bank $b$ & $\begin{array}{l}\text { Binary variable that equals the value of one if bank } b \text { has membership to the largest fixed income platform in Germany (Eurex Exchange), and } \\
\text { zero otherwise. }\end{array}$ \\
\hline Non-trading bank $b$ & $\begin{array}{l}\text { Binary variable that equals the value of one if bank } b \text { does not have membership to the largest fixed income platform in Germany (Eurex } \\
\text { Exchange), and zero otherwise. }\end{array}$ \\
\hline Landesbank $_{b}$ & Binary variable that equals the value of one if bank $b$ is a Landesbank, and zero otherwise. \\
\hline Public support $_{b}$ & Binary variable that equals the value of one if bank $b$ received any form of public support during our sample, and zero otherwise. \\
\hline After public support $b_{b, t}$ & $\begin{array}{l}\text { Binary variable that equals the value of one in all periods after bank } b \text { received public support (including the actual period of receiving the } \\
\text { support), and zero in the periods before. }\end{array}$ \\
\hline Before public support ${ }_{b, t}$ & Binary variable that equals the value of one in all periods before bank $b$ received public support, and zero in the periods after. \\
\hline$\% \Delta$ price $_{i, t-1}$ & Percentage price change of security $i$ from $t-2$ to $t-1$. \\
\hline Capital/ $\mathrm{TA}_{b, t-1}$ & Measures the book value of equity as a fraction of total assets (in \%) for bank $b$ in quarter $t-1$. \\
\hline Tier1-buffer $b, t-1$ & Measures the difference between the Tier 1 capital ratio of bank $b$ at quarter $t-1$ and the required regulatory ratio. \\
\hline Central bank borrowing $/ \mathrm{TA}_{b, t-1}$ & $\begin{array}{l}\text { Measures the total borrowing from the Deutsche Bundesbank (German central bank) as a fraction of total assets (in \%) for bank } b \text { in quarter } \\
t-1 \text {. }\end{array}$ \\
\hline$\Delta$ Credit/TA $\mathrm{TA}_{b-t}$ & Measures the change in total amount of credit as a fraction of total assets (in \%) for bank $b$ in quarter $t-1$. \\
\hline Subprime exposure $/ \mathrm{TA}_{b}$ & Measures the subprime securities holdings (CDOs, MBSs, and ABSs) as a fraction of total assets (in \%) that bank $b$ held in 2006:Q2. \\
\hline Off-balance sheet exposure $/ \mathrm{TA}_{b}$ & Measures the off-balance sheet holdings as a fraction of total assets (in \%) that bank $b$ held in 2006:Q2. \\
\hline Gains on securities $b, i, t-1$ & $\begin{array}{l}\text { Unrealized gains/losses that a bank } b \text { generates with holding the security } i \text { in quarter } t-1 \text { as a fraction of total assets (in \%). We compute } \\
\text { profits by multiplying the change of the market-to-book ratio of security } i \text { with the amount held (in nominal values) by bank } b \text { in quarter } t-1 \text {. } \\
\text { We further cumulate the profits of this security from the quarter, in which it has been purchased, until quarter } t-1 \text {. }\end{array}$ \\
\hline Gains on holdings $b, t-1$ & $\begin{array}{l}\text { Unrealized gains/losses on all securities in the bank's portfolio up to quarter } t-1 \text { as a fraction of total assets (in \%). We compute this by } \\
\text { aggregating the cumulative gains for individual securities held by the bank (described above) at the bank level. }\end{array}$ \\
\hline Gains on pre-crisis holdings $b, t-1$ & $\begin{array}{l}\text { Unrealized gains/losses on all securities up to the quarter } t-1 \text { that the bank held in its pre-crisis portfolio and had maturing dates after } 2009 \text { :Q4 } \\
\text { as a fraction of total assets (in \%). We compute this by aggregating the cumulative gains for individual securities held by the bank (described } \\
\text { above) at the bank level. }\end{array}$ \\
\hline Gains on pre-crisis subprime holdings $s_{b, t-1}$ & $\begin{array}{l}\text { Unrealized gains/losses on all subprime securities (CDO, MBS, and ABS) that the bank held in its pre-crisis portfolio up to the quarter } t-1 \\
\text { as a fraction of total assets (in \%). We compute this by aggregating the cumulative gains for individual securities held by the bank (described } \\
\text { above) at the bank level. }\end{array}$ \\
\hline Profits from derivative trading $/ \mathrm{TA}_{b, t-1}$ & Net profits that bank $b$ generates from its derivatives trading as a fraction of total assets (in \%) in quarter $t-1$. \\
\hline Profits from overall trading $/ \mathrm{TA}_{b, t-1}$ & Net profits that bank $b$ generates from all its trading activities as a fraction of total assets (in \%) in quarter $t-1$. \\
\hline Future default $j, t$ & $\begin{array}{l}\text { Binary variable that equals the value of one if borrower } j \text { defaults on its loan over the subsequent two years of the credit contract after quarter } \\
t \text {, and zero otherwise. }\end{array}$ \\
\hline $\operatorname{Rating}_{i, t}$ & Credit rating of security $i$ in quarter $t$, where rating equals a numeric scale of Moody's rating codes that range from category 'Aaa' through 'C'. \\
\hline Maturity $_{i, t}$ & Number of months remaining (residual maturity) from quarter $t$ onwards until security $i$ matures. \\
\hline
\end{tabular}

